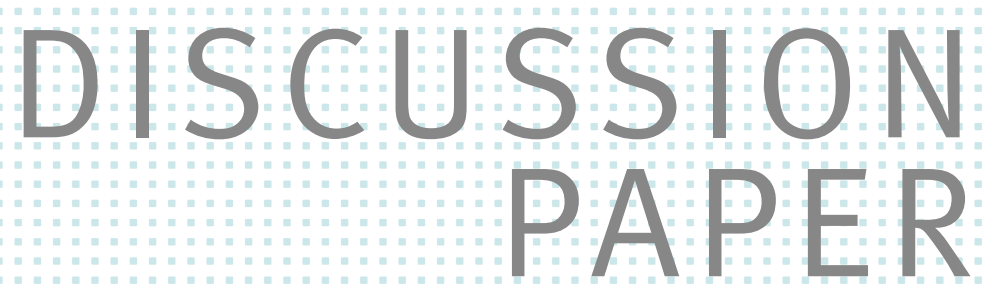

// MATTEO ALPINO, ZAREH ASATRYAN, SEBASTIAN BLESSE, AND NILS WEHRHÖFER

\title{
Austerity and Distributional Policy
}




\title{
Austerity and Distributional Policy*
}

\author{
Matteo Alpino \\ Bank of Italy \\ alpino.mtt@gmail.com \\ Sebastian Blesse \\ ZEW Mannheim \\ sebastian.blesse@zew.de
}

\author{
Zareh Asatryan \\ ZEW Mannheim \& CESifo \\ zareh.asatryan@zew.de \\ NiLs WeHRhÖFER \\ ZEW Mannheim \& University of Mannheim \\ nils.wehrhoefer@gess . uni-mannheim.de
}

\section{June 2020}

\begin{abstract}
What are the effects of austerity on distributional policy? We exploit the autonomy of Italian municipalities in setting non-linear income taxes and the exogenous introduction of a fiscal rule to show that austerity increases income tax progressivity. Consistent with this evidence, we find that in a panel of countries austerity correlates with higher marginal tax rates on top- but not on average-earners. The increase in progressivity in Italy is driven by highskilled mayors, while low-skilled mayors raise taxes uniformly. In the election after the reform, high-skill mayors have higher reelection odds than low-skill mayors, while there was no difference beforehand.
\end{abstract}

JEL Classification: D78, H24, H70.

Keywords: austerity, fiscal rules, non-linear income taxation, difference-in-discontinuity

\footnotetext{
*We thank Thushyanthan Baskaran, Michael Bechtel, Ilaria De Angelis, Matteo Gamalerio, David Gomtsyan, Farid Guriyev, Friedrich Heinemann, Eckhard Janeba, Andreas Kotsadam, Tommy Krieger, Walter Melnik, Enrico Rubolino, Sebastian Siegloch, Hyejeong Sim, Janne Tukiainen, Alfons Weichenrieder as well as seminar participants at VATT Helsinki, University of Cagliari, ZEW Mannheim, University of Mannheim, IIPF congress in Tampere, Armenian Economic Association Winter Workshop, Fiscal Policy Seminar at the German Ministry of Finance, Dondena Workshop on Fiscal Policy, NTA meeting in New Orleans, EPCS meeting in Jerusalem, and ARET meeting at the Bank of Italy for helpful comments. We also appreciate the help of Cristian Usala, and thank Joshua Handke, Kevin Kliemeck and Matilde Cappelletti for valuable research assistance. The views expressed in this paper do not necessarily reflect those of the Bank of Italy.
} 


\section{Introduction}

Large fiscal stimulus packages, such as those enacted during the global financial crisis of 2007-09 or those in response to the Covid-19 pandemic of 2020, lead many governments to engage in some form of austerity in years following the crises. A large academic and policy literature debates the efficiency aspects of fiscal adjustment reforms (see, among others, Alesina et al., 2019). The social and distributional effects of austerity have recently also come under scrutiny by economists, and perhaps even more so by the general public. The popular belief is that austerity hurts the poor disproportionately (Blyth, 2013; Mendoza, 2014; Varoufakis, 2016), and that it has far reaching consequences on social outcomes such as on health (Stuckler and Basu, 2013), violence (Cooper and Whyte, 2017), gender equality (Karamessini and Rubery, 2013), aspects of local governance (Phillips-Fein, 2013), and election outcomes (Dal Bo et al., 2018; Fetzer, 2019), among others.

In this paper we study the effects of austerity on distributional policy. We start by investigating the relationship between cyclically adjusted primary balance (as a measure of austerity) and statutory personal income tax rates (as a measure of distributional policy) in a panel of countries. The estimated relationship, plotted in Figure 1 and shown in Table A.1, shows that conditional on country and year fixed effects, a $1 \%$ increase in the cyclically adjusted primary balance to GDP ratio is associated with a 0.6 percentage point increase $(\mathrm{p}<0.05)$ in the marginal income tax rate at the top (right panel), while we observe no correlation between austerity and marginal income tax rates at mean levels of income (left panel). This preliminary evidence suggests that austerity is associated with higher not lower tax progressivity.

Of course, it is hard to draw definitive conclusions from this exercise, since these regressions do not have a causal interpretation. Therefore, our aim in this paper is to provide the first quasi-experimental evidence on the effect of fiscal austerity on distributional policy. ${ }^{1}$ To do so, we study a large exogenous reduction of

\footnotetext{
${ }^{1}$ Previous quantitative work has mostly appeared in response to the global financial crisis, and it usually finds that periods of fiscal austerity are associated with an increase in income inequality
} 
Figure 1: Fiscal austerity and tax rates at mean (left) and top (right) incomes
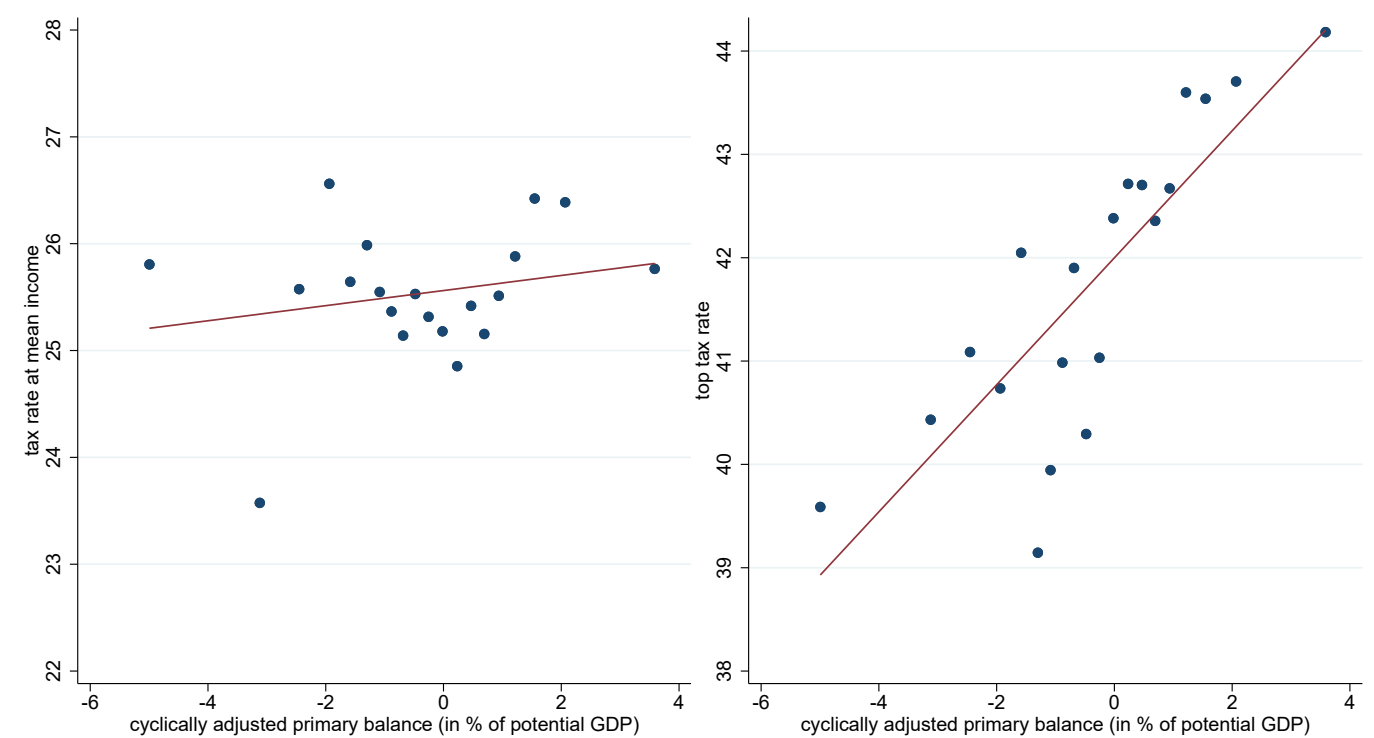

Notes: This graph shows estimates from the following regression $y_{i t}=\gamma_{i}+\lambda_{t}+\beta c a p b_{i t}+\delta X_{i t}+\epsilon_{i t}$, where $y_{i t}$ is either the tax rate at mean incomes (left panel) or at top incomes (right panel), capb $b_{i t}$ is the cyclically adjusted primary balance in percent of potential GDP, $X_{i t}$ includes log GDP per capita and log population as control variables, $\gamma_{i}$ are country fixed effects and $\lambda_{t}$ are year fixed effects. The sample and data are described in Table A.1.

the fiscal space of Italian municipalities caused by the imposition of a fiscal rule by the national government. More specifically, our quasi-experiment relies on a reform in 2013 that extended the budget surplus requirement of the Domestic Stability Pact (DSP) to previously exempted municipalities based on a population cutoff giving rise to a difference-in-discontinuity design. Italy is well-suited to study our research question due to the substantial autonomy that municipalities have over setting local non-linear income taxes (Giommoni, 2019).

Our main finding is that local governments respond to the introduction of the fiscal rule by increasing local income tax rates. The increase is monotonic along the income distribution, but only becomes significant for tax rates on taxpayers located above the median taxable income. The relative effects are quite sizable, with the tax rates on the top decile of the municipal income distribution increasing by $13 \%$ compared to the sample mean, and by about 3.5 times compared to the

(Ball et al., 2013; Chen et al., 2019; Heimberger, 2018; Woo et al., 2013). The micro simulations of Avram et al. (2013) and Paulus et al. (2016) on several European countries present a more nuanced picture on the distributive effects of austerity that depend on country contexts and measures of austerity. 
lowest decile of the income distribution. We estimate that part of this effect is driven by municipalities switching to a progressive tax schedule and increasing the level of the exemption threshold. Since local income tax rates are small in absolute magnitude in Italy, these reform-induced tax rate changes imply only small increases in tax revenues. Whereas annual income tax revenues increase on average by about $5 €$ per capita, revenues from the top bracket increase by over an order of magnitude higher, amounting to about $73 €$ per capita on average. The reform does not seem to affect other taxes or non-tax revenues raised by municipalities. We also do not find evidence for adjustments in total or redistributive spending, suggesting that a reduction of public goods provision is unlikely to offset the progressive effects of the local income tax.

We interpret our findings as the impact of austerity on distributional policy. Considering the introduction of the DSP as a case of austerity is natural because it necessarily required a fiscal adjustment in municipalities where the rule bound. Consistent with this interpretation, previous evidence shows that the DSP induces substantial fiscal consolidation (Chiades and Mengotto, 2015; Coviello et al., 2019; Grembi et al., 2016). Contextual details of the Italian economic situation of the time further reinforce our interpretation: the reform took place in the midst of a severe recession caused by the sovereign crisis, with Italian real GDP shrinking by $3 \%$ in 2012 and by $1.8 \%$ in 2013 , while the central government cut transfer to municipalities in several occasions between 2009 and 2015 (see Figure B.1 and Marattin et al., 2019 for details). Both factors reduced municipal revenues making thus more difficult to comply with the rule without a fiscal adjustment. Furthermore, in these times the DSP, vertically imposed by the national administration upon municipalities, became a symbol of austerity in the eyes of local administrators ${ }^{2}$

\footnotetext{
${ }^{2}$ For example, in his 2016 inaugural speech as national representative of the Italian mayors, Antonio Decaro (mayor of Bari) saluted the abolition of the DSP with these words: "We have recently closed a period of cuts, austerity measures, progressive reduction of resources [...] A difficult period that was interrupted, fortunately, with the 2016 Budget Law which [...] translated in effective and necessary measures: end of indiscriminate transfer cuts, abolition of the DSP [...]
} 
and became grossly unpopular among mayors across the political spectrum. ${ }^{3}$ This situation is similar to the broader context in the European Union, where at the time fiscal rules were being vertically imposed by the European Commission on many national governments, and the Stability Growth Pact was very unpopular among politicians and voters in countries with high public debt and sluggish growth. ${ }^{4}$

This paper is related to a large literature on the political economy of non-linear income taxation (see Persson and Tabellini, 2002, for a review). Our baseline result that, upon an exogenous shock, governments use the instruments of marginal income tax rates and exemption thresholds to tax only those located above the median earner are consistent with Bierbrauer and Boyer (2018) and Bierbrauer et al. (2018) which characterize the conditions of politically feasible non-linear tax reforms. In addition to this theoretical work, our evidence is in line with historical explanations for the occurrence and rise of progressive taxation. This literature emphasizes the role of compensatory arguments as the main mechanism behind the popular support and ultimately the implementation of progressive taxes (Scheve and Stasavage, 2010, $2012,2016)$. The idea is that high taxes on the rich allow politicians to compensate the majority of relatively poor voters for some fundamental unfairness induced by the state. Given that in our sample period Italy endured a double dip recession and that the DSP was unpopular, this line of argument is also consistent with our results.

Next, we study whether mayors, the crucial decision makers at the local level, respond to austerity in a homogeneous manner. Our analysis is motivated by the theoretical work of Bierbrauer and Boyer (2013), who introduce vote-share maximizing politicians with ex-ante quality differences in a Mirrleesian model of income

\footnotetext{
${ }^{3}$ For example, a rally against the DSP organized in November 2012 by the association of Italian municipalities was joined by hundreds of mayors including those of Milano and Torino (centre-left), Roma and Varese (centre-right), and Parma (populist). Mayors rallied behind a banner saying "Let us set our municipalities free from the stupidity pact."

${ }^{4}$ According to a recent survey, Italian members of parliament on average agree with the statement that the "Stability and Growth Pact inappropriately constrains fiscal policy in member states, and should be relaxed." (Blesse et al., 2019). The same opinion is shared by a large majority of respondents in public opinion surveys (SWG, 2017).
} 
taxation. ${ }^{5}$ They show that in equilibrium the high-skilled candidate is able to capitalize on her advantage and target the majority consisting of relatively poorer voters by proposing a progressive tax schedule, whereas the low-skilled politician is left to lobby for the votes of the rich. Consistent with this result, we find that the tax progressivity induced by the reform is driven by high-skilled mayors, which we proxy by having a college degree or working in a high-skill occupation, while other observable characteristics, such as age, gender, party affiliation, do not play a meaningful role. On the contrary, low-skilled mayors rely on flat increases in the local income tax to comply with the reform. This finding is confirmed when we address the issue of selection of mayors by comparing the outcomes of high- and low-skilled politicians elected in close races.

This finding contributes to the literature on how the quality of politicians matters for policy outcomes. High-skilled politicians have been shown to increase economic growth (Besley et al., 2011), to improve fiscal capacity by investing in tax collection (Ferraz et al., 2018), and to provide a higher quality of public goods (Martinez-Bravo, 2017), among other findings. We extend this literature by showing that the competence of politicians also matters for distributional policy.

Finally, we test whether the introduction of the DSP had electoral consequences for the incumbents. While we do not find such evidence for the average mayor, we show that differences in adjustment strategies between high- and lowskilled mayors made for large differences in electoral outcomes. In the first election following the imposition of the fiscal rule, low-skilled incumbents were on average 30 to 37 percentage points less likely to be reelected conditional on running for office again, whereas high-skilled mayors did not experience a significant decline in their reelection prospects. Crucially, these differences in reelection odds only manifest after the reform, and not before. These findings suggest that politicians implement progressive tax reforms in order to stay in office, and that high-skilled mayors are

\footnotetext{
${ }^{5}$ See Bernhardt et al. (2020) for results on how the targeting strategy of two competing parties, in terms of going for the minority of core supporters, the median voter or an outsized majority, depends on the initial imbalance in quality.
} 
more able to use such a strategy than low-skilled mayors.

This finding relates to a rather polarized literature interested in understanding the political costs of fiscal austerity. One strand of this literature finds that incumbent politicians do not face electoral costs when implementing fiscal consolidations at the national level (Alesina et al., 2012; Arias and Stasavage, 2019; Brender and

Drazen, 2008). ${ }^{6}$ On the other hand, a number of papers show that fiscal austerity has negative effects on voter support for the incumbent (Hübscher et al., 2018; Talving, 2017) as well as on broader socio-political outcomes such as increasing support for right-wing populism (Dal Bo et al., 2018; Fetzer, 2019), or increasing social unrest (Passarelli and Tabellini, 2017; Ponticelli and Voth, 2019). We contribute by showing that austerity can indeed carry significant electoral costs, but that these costs depend on the consolidation strategy. In particular, we show that electoral costs can be mitigated by mainly increasing taxes on high-income earners.

\section{Institutional Setup}

\subsection{Municipal Fiscal Rule}

Since 1999, Italian municipalities have been subject to a fiscal rule, the Domestic Stability Pact (Patto di stabilita' dei comuni), introduced by the national government. ${ }^{7}$ Originally, all municipalities were subject to the fiscal rule, but in 2001 those below 5,000 inhabitants were excluded. In 2013, the threshold was lowered to 1,000,

\footnotetext{
${ }^{6}$ Possible explanations are that voters are fiscally conservative (Peltzman, 1992), that leaders implement fiscal austerity in times and as part of policy packages that allow them to electorally survive these reforms (Bansak et al., 2020), or that the divergent framing of the same issue provided by partisan media mitigates voter responses (Barnes and Hicks, 2018).

${ }^{7}$ The main goal of fiscal rules is to achieve fiscal sustainability. Currently over ninety countries have such rules (Eyraud et al., 2018). Asatryan et al. (2018) find constraining effects of balanced budget rules on debt, but only for a class of rules that are enshrined in national constitutions, while Eliason and Lutz (2018) show that a comprehensive state-level rule in Colorado does not affect public finances, which is partly due to non-compliance with the rule. A meta-study by Heinemann et al. (2018) finds that numerical fiscal rules constrain fiscal policy, but results become much less assuring once one accounts for endogeneity. Fiscal rules have also been shown to curb corruption (Daniele et al., 2019), to alleviate political budget cycles (Repetto, 2018), to worsen the selection of politicians (Gamalerio, 2019), and to have wider macroeconomic implications (Combes et al., 2018), among other findings.
} 
which is the reform that we exploit. Finally, in 2016, the Domestic Stability Pact was abolished and a balanced budget rule for all municipalities was introduced.

In our period of analysis, the Domestic Stability Pact's target object has always been the Saldo Finanziario, which is defined as the difference between expenditures and revenues, net of repayment of outstanding debt and of lending. Some budget items were always or occasionally excluded from the Saldo Finanziario (e.g. spending for natural disaster relief, EU structural funds). The formula to calculate the numerical target varied over the years, but it was usually defined as a function of budget items in previous years (see Table B.1).

Monitoring of compliance by the central government was tightened in 2008 with the introduction of a compulsory reporting system, and of severe punishment for non-compliers by the central government (Coviello et al., 2019). For instance, punishments include bans on hiring, cuts of transfers from the central government (proportional to the deviation from the rule), salary cuts to mayors and city councilors, a growth cap on current spending at zero percent as well as a ban on new municipal debt. Qualitative evidence from the Ministry of the Interior suggests that the central government implemented the reform quite thoroughly. ${ }^{8}$ Dovis and Kirpalani (2020) show that the fiscal behavior of local governments will crucially depend on central government's reputation, and the strict regulations and enforcement practices of the Italian context suggests that it is very unlikely that Italian local governments tried not to comply with the DSP.

\subsection{Municipal Governance}

Municipal governments are composed of a city council, an executive committee, and the mayor. In municipalities with less than 15,000 inhabitants, each candidate for the mayoral office has to be supported by a list of candidates for the city council. Voters cast a single vote for a mayoral candidate, and can express one preference

\footnotetext{
${ }^{8}$ More than one hundred municipalities faced legal procedures according to ministerial decrees available on the website of the Ministry of the Interior.
} 
vote for one council candidate within the same list. The mayoral candidate who gets the most votes is elected as mayor. The seats in the city council are split as follows: $2 / 3$ to the list of the mayor, and $1 / 3$ split across the other lists in proportion to their votes shares. The mayor appoints the members of the executive committee, and can also remove them from office at any time. The mayoral term is five year long, and the mayor cannot serve for more than two consecutive terms. ${ }^{9}$ These institutional details make the mayor the most important player in municipal politics, while the city council's influence is more limited. The list supporting a mayoral candidate is sometimes backed by national-level parties or coalitions, but is often independent (so-called civic lists), especially in small municipalities. Also, since being a politician in a small town is not a full-time job, most mayors work in their normal job while being in office.

\subsection{Municipal Fiscal Policy}

The municipal budget is financed with transfers from higher levels of government and international institutions, and by municipal resources such as local taxes and fees connected to the use of public services. Local taxation plays an important role in municipal revenues, averaging about $21 \%$ of total revenues in our sample period (see Figure B.1). The three largest tax instruments in terms of revenues are the property tax, the local income tax and the waste tax, accounting for $8.7 \%$, $4.4 \%$ and $7.9 \%$ of total revenues in 2015 respectively. In this paper, we focus on the local income tax surcharge, as it allows different degrees of progressivity and its distributional impact is straightforward. The property tax and the waste tax potentially also have distributional consequences, but those are more complicated to detect and to analyze. ${ }^{10}$

In 1999, the local income tax was introduced as a municipal surcharge on

\footnotetext{
${ }^{9}$ This was extended to three terms in 2014 for municipalities below 3,000 inhabitants.

${ }^{10}$ For more details on the distributional consequences of these fiscal instruments see Messina and Savegnago (2014) and Messina et al. (2018)
} 
the national income tax to grant municipalities more tax autonomy. In our sample period, the income brackets of the national income tax were split at $15,000 €$, $28,000 €, 55,000 €$, and $75,000 €$, with their respective marginal tax rates being $21 \%$, $27 \%, 38 \%, 41 \%$ and $43 \% .{ }^{11}$ In general, the tax base is composed of wage income, pension income, self-employed income, capital income, rents, and other sources of income. However, income from several sources can be subject to alternative and more favorable taxation (e.g. rents from real estate, investment in government bonds, self-employed income below a certain threshold), so the bulk of the taxable income consists of wage and pension income. ${ }^{12}$

The revenues from the municipal surcharge are based on the residency principle and flow completely to the municipal budget. Starting in 1999, it allowed municipalities to apply uniform tax rates of up to $0.5 \%$ of taxable income on top of the national tax rates. In the period from 2007 to 2011, the cap was raised to $0.8 \%$ and municipalities were given the autonomy to set an exemption threshold: tax payers with income below the threshold were fully exempted from the tax, while those above would pay a tax calculated on their total income. Since 2012, municipalities can also set differentiated tax rates in every bracket of the national income tax schedule. In other words, since 2007 municipalities can levy non-linear income taxes. This setting allows us to study the progressivity of income taxation at the local level.

The adoption of differentiated tax rates by municipalities has evolved quickly over time and increased even further with the 2012 reform (Giommoni, 2019). Restricting attention to small municipalities (below 2,500 inhabitants), no municipality operated under a regime with an exemption threshold and a flat tax, $67 \%$ implemented a flat tax without exemption, and 33\% did not introduce any surcharge in 2007. In $2015,8 \%$ operated a system with five tax rates, with or without exemption,

\footnotetext{
${ }^{11}$ The final tax bill is the gross tax bill net of deductions (detrazioni). The gross tax bill is calculated applying the tax rates on taxable income. The taxable income is calculated as total income net of exemptions (deduzioni).

${ }^{12}$ Approximately $80 \%$ both in terms of taxpayers and of taxable income in 2011.
} 
$12 \%$ implemented a flat tax with exemption, $56 \%$ implemented a flat tax without exemption, and $24 \%$ did not have any surcharge. Conditional on having a exemption threshold, the average threshold is about $10,000 €$ with considerable variation around the mean (see Figure B.2). Giommoni (2019) analyzes the 2012 introduction of differentiated tax rates among Italian municipalities. He finds that the reform allows mayors to strategically target different income groups generating an election cycle: tax rates decrease before elections and increase afterwards. Giommoni (2019) also shows, using evidence from google searches and survey data, that the municipal income surcharge is a salient fiscal instrument for taxpayers. This is consistent with the fact that the amount paid due to this tax is usually clearly visible on the monthly payslips received by employees and retirees. Finally, Giommoni (2019) also finds that the cyclical manipulation of the tax rates by mayors increases their re-election odds.

Municipalities account for about $10 \%$ of total public expenditures (Grembi et al., 2016). They are responsible for providing a variety of public services, such as administrative services (30\% of municipal expenditures in our sample period 20072015), waste and water management (24\%), public transport and maintenance of municipal roads (15\%), social services (8\%), education services (7\%), culture and recreation $(5 \%)$, economic development and tourism (3\%), and local police and judiciary $(2 \%)$.

Spending on social and educational programs is of special importance to us, given their potential redistributive nature and Italian municipalities' relatively large discretion over these items. Social spending includes, among others, assistance to poor people, child care, or care for elderly. Education expenditures on the municipal level comprise of spending for pre-school and primary school services, such as refectories and school buses. In our sample period, Italian municipalities are only allowed to take up loans to finance new investment expenditures if the total amount of interest paid was lower than a certain fraction of revenues from taxes, fees and 
transfers. ${ }^{13}$ The main source of borrowing for small municipalities are loans from the Italian Public Investment Bank (Cassa Depositi e Prestiti) accounting for almost $80 \%$ of debt holdings.

\section{Data}

\subsection{Sample}

Our sample starts in 2007, the first year municipalities were allowed to levy nonlinear income taxes, and ends in 2015, since all municipalities were subject to a new rule in 2016. We apply a number of restrictions on our sample. First, we drop all observations that are part of a union for inter-municipal cooperation (Unione dei Comuni) and at the same time have less than 1,000 inhabitants, since these municipalities are subject to the fiscal rule irrespective of their population (931 municipalities). Second, we drop all municipalities located in one of the five autonomous regions (Friuli-Venezia Giulia, Sardegna, Sicilia, Trentino-Alto Adige, and Valle d'Aosta), since they are granted a special status by the Italian constitution allowing them to set their own rules (1,392 municipalities). Third, we drop all municipalities that merged in the sample period (79 municipalities). Altogether, our final sample consists of 6,638 municipalities, which represent about $82 \%$ of all Italian municipalities.

Figure B.3 shows a map of municipalities in our sample, distinguishing between municipalities below 1,000 inhabitants (blue) and those between 1,000 and 2,500 (red). Table B.3 shows summary statistics of all variables for the whole sample as well as for municipalities below and above 2,500 inhabitants.

\footnotetext{
${ }^{13}$ The fraction varied over time, from $15 \%$ in 2007 to $10 \%$ in 2014 .
} 


\subsection{Municipal Tax Rates}

We collect annual information on the local income tax from the Italian Ministry of Finance. This includes marginal tax rates for all income brackets and exemption levels at the municipal level. We also obtain the (approximate) municipal-level income tax base distribution from the Italian Fiscal Agency (Agenzia delle Entrate). In particular, for every municipality we observe both the number of taxpayers and the tax base in a number of income brackets. ${ }^{14}$ We make the simplifying assumption that taxpayers are uniformly distributed within the brackets in order to construct income deciles on the municipality level. This allows us to know the tax rates that apply to each income decile of the respective municipality, e.g., the statutory tax rate that a household earning as much as the 90th percentile of the municipal income distribution has to pay. Using these tax rates as outcome variables allows us to gauge which part of the distribution is affected by changes in tax policy. ${ }^{15}$ As discussed above, one can distinguish between three different tax regimes: a uniform tax, an exemption level and a uniform tax, or a fully differentiated tax schedule. We plot the sample mean of the average tax rates for municipalities in the three tax regimes before (Figure 2a) and after the fiscal rule reform (Figure 2b). As the blue line indicates, the average uniform tax rate is about $0.48 \%$. For both municipalities with an exemption threshold and those with a fully differentiated tax schedule, the mean tax rate monotonically increases along the municipal income distribution.

To test the distributional effect of the fiscal rule we employ several outcome measures. First, we directly look at the tax rates at the nine income deciles of the municipal income distribution. Second, we study the level of the exemption threshold. Third, we use a binary indicator of whether a given municipality has a progressive tax system or not. Fourth, to obtain a comprehensive measure of progressivity, we use two indicators from the literature: the average and marginal

\footnotetext{
${ }^{14}$ See Figure B.4 for a histogram of the number of taxpayers in each bracket.

${ }^{15} \mathrm{We}$ also use the average tax rate paid on annual incomes from 5,000 to $75,000 €$ as alternative outcomes.
} 
Figure 2: Municipal income tax: average tax rates

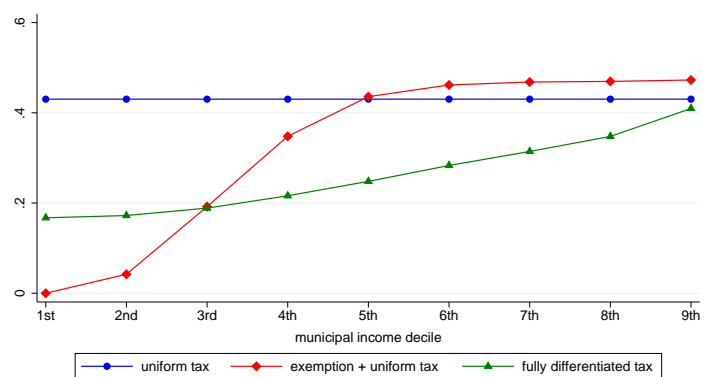

(a) before reform

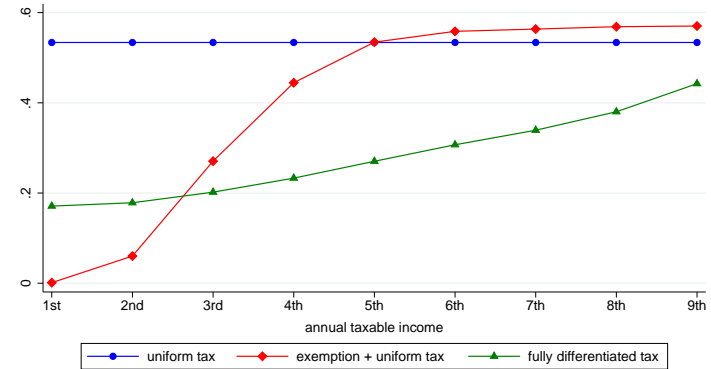

(b) after reform

Notes: The figure presents the mean average tax rates in the deciles of the municipal income distribution for three groups of municipalities: those with a uniform tax (blue line), those that have an exemption level and a uniform tax rate that applies to income exceeding the exemption level (red line), and those with a fully differentiated tax schedule (green line). The sample includes only municipalities with less than 2,500 residents. Panel (a) presents data for the period 2007-2012; panel (b) for the period 2013-2015.

rate progression (Peter et al., 2010). We construct these variables by running the following regression for each municipality-year pair $(i, t)$ separately:

$$
\text { TaxRate }_{y i t}=\beta_{0}+\beta_{1} \log (y)+\epsilon_{i t y} \forall y \in\{1000,2000, \ldots, 99000,100000\}
$$

where Tax Rate $_{\text {yit }}$ is the average (marginal) tax rate at income $y$ in municipality $i$ in year $t$, and $\beta_{1}$ is an estimate of the average (marginal) rate progression. We normalize the progressivity measures with their sample standard deviations to ease interpretation. The resulting coefficient is by construction negative for regressive, zero for flat, and positive for progressive tax schedules.

Furthermore, we calculate income tax revenues by income brackets. Specifically, we take the product of the total tax base and the average tax rate for each individual bracket. To derive the average tax revenues per taxpayer, we then divide by the number of tax payers in the specific bracket.

\subsection{Municipal budget}

We complement the data above with municipal budget data from the Italian Ministry of the Interior (Certificati Consuntivi). These include detailed accounts of revenues 
and expenditures. Budgets report figures according to two accounting criteria: cash and accrual bases. We use the latter, since policy changes are reflected in accrual accounts more quickly. We convert all monetary values into 2015 euro and per capita figures using the CPI series and annual population counts from the Italian National Institute of Statistics (ISTAT). Furthermore, we winsorize all budget variables at the first and 99th percentile to account for outliers.

Expenditure figures are split between capital and current spending, and are further disaggregated in broad categories (e.g. education, social). Revenues are available by their source (e.g. local income tax surcharge, transfers from central government). We rely on the officially defined deficit (disavanzo) in the accounts, which is the difference between revenues and expenditures plus the difference between revenue carry-overs and expenditure carry-overs from preceding years. Carry-overs are the difference between the figures calculated according to the cash and accrual bases (e.g. credit vis-a-vis taxpayers, or debt vis-a-vis suppliers). Therefore, the official deficit accounts for obligations originated in previous years, which still weight on the public finances. According to this official measure of deficits, $54 \%$ of all municipalities in our sample are in surplus.

\subsection{Politician and Election Data}

We collect information on local elections from the historical electoral archive, and information on politicians from the registry of local public office holders. Both datasets are maintained by the Italian Ministry of the Interior. The first database includes the names of all the candidates and of the lists supporting them, and reports information on election results. This allows us to construct both a rerun and reelection dummy for incumbents. The former is equal to one if the incumbent is not term-limited and runs again, and equals zero in case the incumbent is not term-limited but does not run again. The latter variable equals one for incumbents that run again and are reelected, and is zero for those who rerun and fail to be 
reelected.

The second database has demographic information on all individuals who ever held municipal public office, that is mayors, members of the executive committee, and councilors. Usually runners-up are elected to the city council, so that we also have information on them unless they give up their seat immediately after the election. Therefore, we have information on birthplace, party, (potential) term limit, gender, (former) occupation and education level for both the mayor and the runnerup. Using these variables, we construct our two measures of politician's quality, a dummy for having a college degree and a dummy for being employed in a high-skill profession before becoming a politician. ${ }^{16}$ We merge the two databases by matching on name, surname, year and municipality code in order to obtain background information on mayors and runners-up. The matching is successful in $70 \%$ of the cases. $^{17}$

\subsection{Municipal Characteristics}

We collect several further (time-invariant) variables on municipal characteristics from the 2011 census: the share of female, college-educated, and inhabitants older than 60 years as well as geographic variables such as altitude, geographic area and a dummy for coastal location. The annual population numbers are retrieved from ISTAT. We calculate the yearly share of income held by the top income earners (more than 55,000€) from the tax base data by the Italian Fiscal Agency.

\footnotetext{
${ }^{16}$ For the latter, we rely on the ISTAT classification of occupations (ISTAT, 2013). We classify occupations in category 1 (legislators, entrepreneurs and managers) and 2 (intellectual, scientific and highly specialized occupations) as high-skill occupations. Among mayors from high-skill occupations, $76 \%$ hold a college degree, whereas among those from other occupations only $27 \%$ have a college degree.

${ }^{17}$ Non-matches are likely due to second-placed candidates not joining the city council. Table B.4 of the Appendix compares the covariates of matched and non-matched mayors.
} 


\section{Empirical Strategy}

\subsection{Difference-in-Discontinuity Design}

Our empirical strategy relies on a natural experiment resulting from the extension of the fiscal rule in the year 2013 to municipalities that were previously exempted. In our sample period of 2007-2015, the Domestic Stability Pact applied to municipalities with 5,000 or more inhabitants until 2013, and to municipalities with 1,000 or more inhabitants from 2013 to 2015. One possible strategy could be a comparison of municipalities around the 1,000 threshold using only data for the period 20132015 in a classic regression discontinuity design. However, other policies change discontinuously at the 1,000 cutoff (see Table B.2 for details) and thus the standard continuity assumption is violated.

In order to isolate the effects of the fiscal rule, we employ a difference-indiscontinuity design (Asatryan et al., 2017; Grembi et al., 2016). The intuition behind this empirical strategy is that a confounding policy jump can be netted out if the policy is time-constant. This assumption holds in our setup, as all of the confounding policy discontinuities are constant over the whole sample period. This implies that one can estimate the confounding effect at the 1,000 threshold in the years before 2013 and subtract it from the compounded fiscal rule and confounding effect estimated at the 1,000 threshold between 2013 and 2015. In other words, this strategy amounts to a difference-in-differences design evaluated at the 1,000 threshold. ${ }^{18}$

More formally, let $Y_{i t}$ be an outcome variable in municipality $i$ at time $t$ (e.g. tax progressivity) and $\tilde{p}_{i t}=p_{i t}-1,000$ its normalized population in the previous year. According to the law, the treatment status of a municipality is based on the population of the preceding year. ${ }^{19}$ We therefore use $\tilde{p}_{i t-1}$ as our forcing variable,

\footnotetext{
${ }^{18}$ We do not evaluate the change of the 5,000 inhabitants threshold, since there is a simultaneous policy change of gender quotas in local elections in 2013 (see Table B.2).

${ }^{19}$ Consistent with the institutional framework, we are using the yearly population numbers from ISTAT.
} 
where at the cutoff the treatment status jumps sharply from 0 to 1 . The differencein-discontinuity estimator can be written as follows:

$$
\begin{aligned}
\hat{\tau}_{d i f f-i n-d i s c}= & \left(\lim _{p \rightarrow 0^{+}} E\left[Y_{i t} \mid \tilde{p}_{i t-1}=p, t \geq 2013\right]-\lim _{p \rightarrow 0^{-}} E\left[Y_{i t} \mid \tilde{p}_{i t-1}=p, t \geq 2013\right]\right)- \\
& \left(\lim _{p \rightarrow 0^{+}} E\left[Y_{i t} \mid \tilde{p}_{i t-1}=p, t<2013\right]-\lim _{p \rightarrow 0^{-}} E\left[Y_{i t} \mid \tilde{p}_{i t-1}=p, t<2013\right]\right)
\end{aligned}
$$

where the first row describes the jump in the outcome variable at the threshold between 2013 and 2015 (i.e. the compounded fiscal rule and confounding effect), and the second row subtracts the jump in the outcome variable before the reform (i.e. only the confounding effect).

We implement this estimator using a local linear regressions as in Grembi et al. (2016) and estimate the following equation: ${ }^{20}$

$$
\begin{aligned}
Y_{i t}= & \beta_{0}+\beta_{1} \tilde{p}_{i t-1}+T_{i t}\left(\beta_{2}+\beta_{3} \tilde{p}_{i t-1}\right)+\operatorname{Reform}_{t}\left[\left(\beta_{4}+\right.\right. \\
& \left.\left.\beta_{5} \tilde{p}_{i t-1}\right)+T_{i t}\left(\beta_{6}+\beta_{7} \tilde{p}_{i t-1}\right)\right]+\epsilon_{i t} \quad \forall(i, t) \text { s.t. }\left|\tilde{p}_{i t-1}\right|<h^{\star}
\end{aligned}
$$

where $T_{i t}$ takes the value of one if municipality $i$ is subject to the fiscal rule in year $t$, Reform $t$ is a dummy equaling one from 2013 to 2015, and $h^{\star}$ is the optimal bandwidth determined by the algorithm suggested by Grembi et al. (2016). ${ }^{21}$ Since the results of local linear regressions may be sensitive to the choice of the bandwidth, we also estimate results obtained with different bandwidths. Standard errors are clustered at the municipal level to account for arbitrary serial correlation in the error term. The local average treatment effect (LATE) of the fiscal rule is then identified by the coefficient $\beta_{6}$.

The difference-in-discontinuity estimator identifies the effect of interest if the following identifying assumptions are met. First, as discussed above, other confounding variables can change discontinuously at the threshold, but we must assume that

\footnotetext{
${ }^{20} \mathrm{We}$ also estimate global polynomial regressions with varying polynomial degrees.

${ }^{21}$ We conduct a standard RD before and after the reform using the STATA command rdrobust (see Calonico et al., 2014) and then take the average of the two optimal bandwidths.
} 
the change is time-constant. We test this assumption of local parallel trends by means of placebo reforms. That is, we pretend that the reform was implemented in some earlier year instead of 2013, and then re-do the baseline analysis on the pre-reform sample. Second, in contrast to a classical regression discontinuity design, where there cannot be any manipulation of the running variables, the difference-indiscontinuity estimator allows for time-constant sorting unrelated to the reform. If municipalities were to react to the reform by manipulating their population numbers in order to avoid the fiscal rule, we would have selection bias in the treatment and control assignment. We test this assumption with McCrary density tests both before and after the reform, as well as with a density test of the change in density because of the reform. One important caveat is that, even when our identifying assumptions hold, we are estimating the local average treatment effect of the fiscal rule. That means our results only apply to small municipalities and are not representative for all Italian local governments.

\subsection{Heterogeneous Effects}

To examine the mechanisms driving our results, we also test for heterogeneous effects. We put special focus on the mayor's quality measured by having a college education or coming from a high-skill occupation. Following the literature on heterogeneous effects in an RD setup (see Becker et al., 2013), we interact every term in equation 2 with a dummy for being a high-skilled mayor $D_{i t}$ :

$$
\begin{aligned}
Y_{i t}= & \beta_{0}+\beta_{1} \tilde{p}_{i t-1}+T_{i t}\left(\beta_{2}+\beta_{3} \tilde{p}_{i t-1}\right)+\operatorname{Reform}_{t}\left[\beta_{4}+\beta_{5} \tilde{p}_{i t-1}+T_{i t}\left(\beta_{6}+\beta_{7} \tilde{p}_{i t-1}\right)\right]+ \\
& D_{i t}\left[\beta_{0}^{i n t}+\beta_{1}^{i n t} \tilde{p}_{i t-1}+T_{i t}\left(\beta_{2}^{i n t}+\beta_{3}^{i n t} \tilde{p}_{i t-1}\right)+\operatorname{Reform}_{t}\left[\beta_{4}^{i n t}+\beta_{5}^{i n t} \tilde{p}_{i t-1}+T_{i t}\left(\beta_{6}^{i n t}+\right.\right.\right. \\
& \left.\left.\left.\beta_{7}^{i n t} \tilde{p}_{i t-1}\right)\right]\right]+\gamma_{i}+X_{i t}+\epsilon_{i t} \quad \forall(i, t) \quad \text { s.t. }\left|\tilde{p}_{i t-1}\right|<h^{\star}
\end{aligned}
$$

The heterogeneous treatment effect is then measured by $\beta_{6}^{i n t} . X_{i t}$ includes dummies indicating whether the mayor is female, has a college degree, is backed by 
a left-wing, right-wing or centrist party, is term-limited, her age and her win margin in the last election, the number of years to the next election, as well as the top income share and pre-reform deficits of the municipality. ${ }^{22}$

We also include municipality fixed effects $\gamma_{i}$ to absorb any time-invariant heterogeneity. Nevertheless, we cannot fully exclude the possibility of unobserved timevarying confounding variables determining both the mayor's quality and our outcome of interest. For example, if municipalities whose population has a higher preference for redistribution tend to elect more skilled mayors, then we would erroneously attribute the estimated increase in progressivity to mayoral quality rather than to the population's preferences.

For this reason, we turn to a more exogenous source of variation in the mayor's quality. We exploit close mixed elections, i.e. races in which the winning candidate and runner-up have a different educational level. ${ }^{23}$ First, we restrict our sample to municipalities whose mayors have been elected in a mixed election. Next, we subtract the vote share of the non-college candidate from that of the college-educated candidate to get the vote margin $v m_{i t}$, which acts as our running variable. For positive $v m_{i t}$, the college-educated candidate wins the election, whereas if $v m_{i t}$ is negative, the non-college candidate wins. Our identifying variation then stems from close elections, comparing municipalities, in which the college-educated candidate barely won, to those in which she barely lost. More formally, let $D_{i t}$ be an indicator that takes the value one if the mayor of municipality $i$ in year $t$ is college-educated. We then estimate the following equation:

$$
Y_{i t}=\beta_{0}+\beta_{1} v m_{i t}+D_{i t}\left(\beta_{2}+\beta_{3} v m_{i t}\right)+X_{i t}+\epsilon_{i t} \quad \forall(i, t) \quad \text { s.t. }\left|v m_{i t}\right|<h
$$

\footnotetext{
${ }^{22}$ In some specifications, we add additional interaction terms from $X_{i t}$ other than $D_{i t}$ to test their relative importance in a "horse race".

${ }^{23}$ This strategy has been extensively used in the literature on the effect of female mayors (see, for example, Baskaran and Hessami, 2018). We focus on mixed races between mayors of different education levels since the number races between mayors from low- and high-skill occupations is considerably smaller.
} 
where $X_{i t}$ includes all control variables described above, as well as additional characteristics of the second-placed candidate (gender, age and party), and $h$ is the chosen bandwidth. The effect of having a college-educated mayor is then identified by $\beta_{2}$. The most important identifying assumption is that the education level is the only characteristic that changes at the threshold. We test this by using other observable characteristics from $X_{i t}$ as outcome variables to see whether they also jump at the threshold.

In a last step, we combine equations 3 and 4 to identify our heterogeneous effects model using only the variation in the quality of the mayor induced by close elections. That is, we interact every term in equation 3 with the vote margin between college-educated and non-college-educated candidates and estimate it on the sample of mixed elections. By comparing college-educated and non-college mayors that barely won in a mixed election, we effectively control for unobserved confounders that could possibly drive both the mayor's educational level and tax policy.

\section{Results}

\subsection{Baseline Results}

We start by presenting some graphical evidence of our results. Figure 3 shows standard RD graphs estimated separately on the pre-reform (2007-12, on the left) and post-reform (2013-15, on the right) samples for four outcome variables in subfigures: a) income tax rate at the first decile, b) income tax rate at the ninth decile,

c) average rate progression, and d) a dummy for a progressive tax. Each graph plots local means of the outcome variable in ten normalized population bins on each side of the threshold, and a linear fit of the data estimated separately on each of them. Before the reform, the figure does not show a visible jump at the threshold for any of the outcome variables. After the reform, we observe a positive jump in the average tax rate at the first decile, and a more sizable one for the tax rate at the 
Figure 3: Regression discontinuity plots: tax progressivity before and after the reform
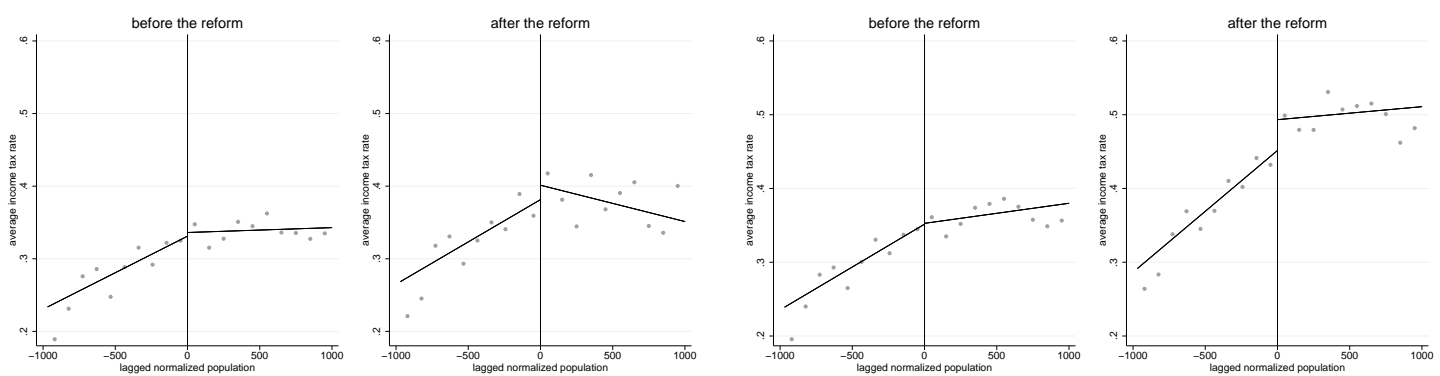

(a) income tax rate at the 1 st decile
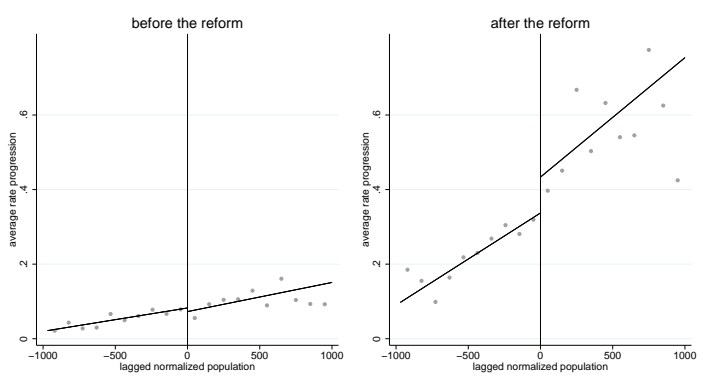

(c) average rate progression

(b) income tax rate at the 9 th decile
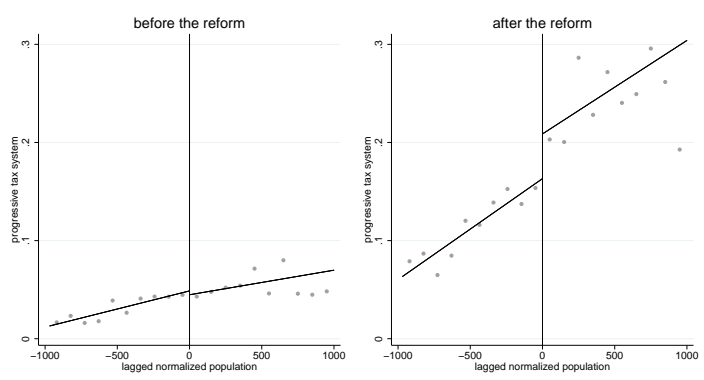

(d) progressive tax

Notes: The reform is the introduction of the fiscal rule for municipalities above 1,000 inhabitants in 2013. Each graph is a regression discontinuity plot for pre-reform years (2007-12, on the left) and post-reform years (2013-15, on the right). The outcome variable is reported underneath each graph. The running variable is lagged normalized population. Plots are obtained with the STATA command reported underneath each graph. The running variable is lagged normalized population. Plots are obtained with the STATA command
rdplot (Calonico et al., 2015) organizing the data in 10 bins on each side of the threshold. The lines are linear fits estimated separately rdplot (Calonico et al., 2015$)$ side of the threshold.

ninth decile. This preliminary graphical evidence suggests that the reform induced a disproportionate increase in the tax for higher incomes. The finding is confirmed by the fact that both measures of progressivity display a positive jump at the threshold in the post-reform years, but not in pre-reform years (panels c and d).

Next, we turn to the estimates obtained from the difference-in-discontinuity estimation (equation 2). Figure 4 plots the local average treatment effect (LATE) of the reform on the average tax rates at all deciles of the municipal income distribution (estimates are shown in Table 1). We find that, first, all point estimates are positive. This is consistent with the interpretation that municipalities raise local income taxes to comply with the fiscal rule. Second, the size of the point estimates is monotonically increasing along the municipal income distribution. Third, the estimated effect on the top tax rate translate to about $13 \%$ of the sample mean, and 
Figure 4: Effect of the reform on the income tax rate at different income deciles

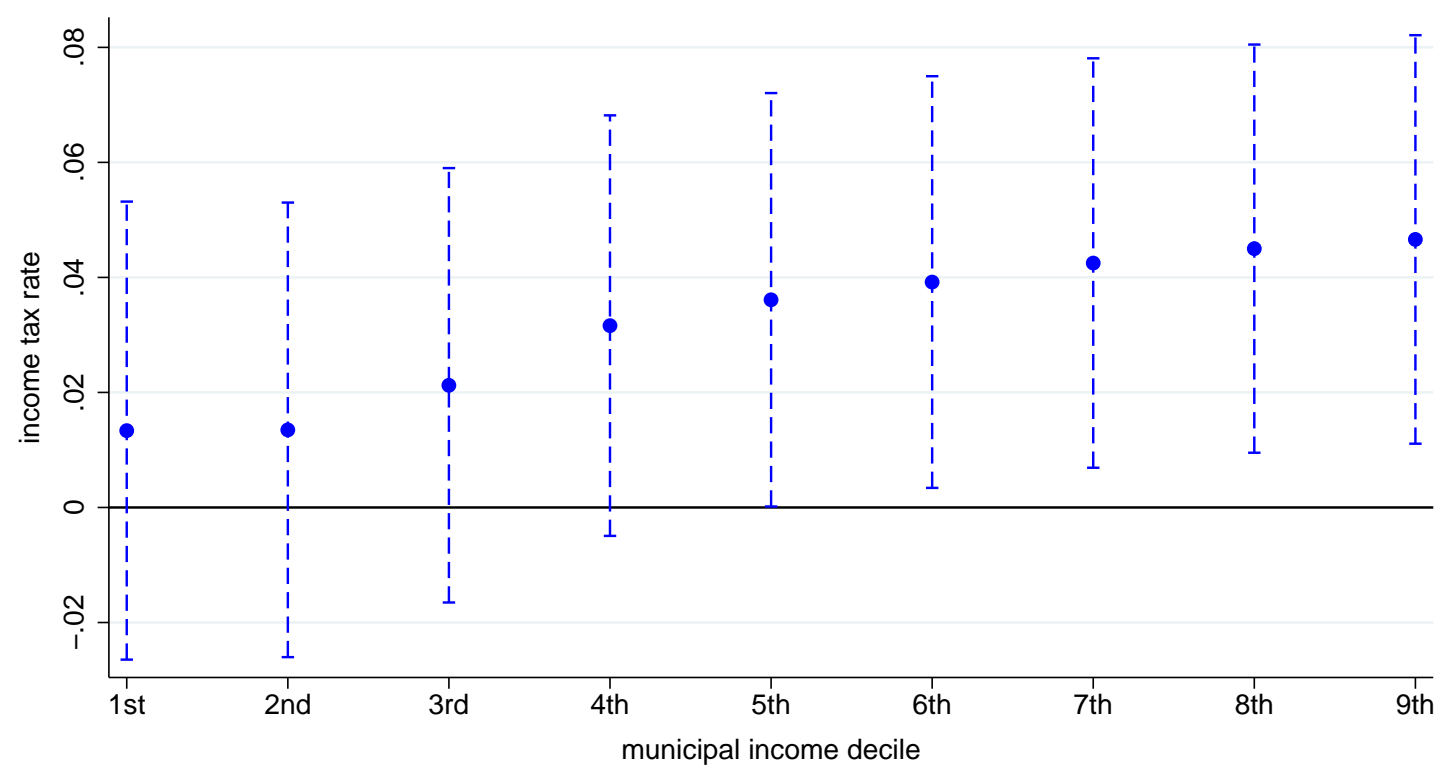

Notes: The reform is the introduction of the fiscal rule for municipalities above 1,000 inhabitants in 2013. The figure plots the local average treatment effects also reported in Table 1 and their $95 \%$ confidence bands. The LATEs are from difference-in-discontinuities models estimated with a separate local linear regression for each tax rate and correspond to $\beta_{6}$ in equation 2 . The bandwidth is selected following Grembi et al. (2016). The deciles refer to the income distribution in each municipality.

is about 3.5 times as large as the estimated tax rate effect on the lowest earners.

To test whether the estimated effects on high-earners are statistically larger than the effects on low-earners, we re-estimate equation 2 for all nine tax rates jointly, with seemingly unrelated regressions (SUR). ${ }^{24}$ We then implement several one-sided Wald tests with a null hypothesis that the effect on higher incomes is not larger than the effect on lower incomes. We present the p-values of all these tests in Table 1. Overall, we can reject the null hypothesis at the $5 \%$ or $10 \%$ level for almost all comparisons.

Alternatively, we also use the average tax rates at annual incomes from 5,000 to $75,000 €$ as outcomes. The effects are again positive for all tax rates and monotonically increasing in income, but only significant at the $95 \%$ level for incomes above the national median income (see Figure C.2). As before, one-sided Wald tests reject the hypothesis that there are no differences between the effects on high- and

\footnotetext{
${ }^{24}$ We use SUR because the tax rates along the income distribution are jointly determined by the municipal government, and thus can not be considered as independent outcome variables. As such, the confidence intervals plotted in Figure 4 are not useful for testing whether effects on different tax rates are significantly different from each other.
} 
Table 1: Effect of the reform on the income tax rate at different income deciles

\begin{tabular}{|c|c|c|c|c|c|c|c|c|c|}
\hline & $\begin{array}{c}(1) \\
\text { 1st decile }\end{array}$ & $\begin{array}{c}(2) \\
\text { 2nd decile }\end{array}$ & 3rd decile & $\begin{array}{c}(4) \\
\text { 4th decile }\end{array}$ & $\begin{array}{c}(5) \\
5 \text { th decile }\end{array}$ & $\begin{array}{c}(6) \\
6 \text { th decile }\end{array}$ & $\begin{array}{c}(7) \\
7 \text { th decile }\end{array}$ & $\begin{array}{c}(8) \\
\text { 8th decile }\end{array}$ & $\begin{array}{c}(9) \\
9 \text { th decile }\end{array}$ \\
\hline LATE & $\begin{array}{c}0.013 \\
(0.020)\end{array}$ & $\begin{array}{c}0.013 \\
(0.020)\end{array}$ & $\begin{array}{c}0.021 \\
(0.019)\end{array}$ & $\begin{array}{c}0.032^{*} \\
(0.019)\end{array}$ & $\begin{array}{l}0.036^{* *} \\
(0.018)\end{array}$ & $\begin{array}{l}0.039^{* *} \\
(0.018)\end{array}$ & $\begin{array}{l}0.043^{* *} \\
(0.018)\end{array}$ & $\begin{array}{l}0.045^{* *} \\
(0.018)\end{array}$ & $\begin{array}{l}0.047^{* *} \\
(0.018)\end{array}$ \\
\hline$>$ 1st decile & - & 0.488 & 0.216 & 0.061 & 0.035 & 0.022 & 0.012 & 0.008 & 0.007 \\
\hline$>$ 2nd decile & - & - & 0.194 & 0.049 & 0.027 & 0.016 & 0.009 & 0.006 & 0.005 \\
\hline$>$ 3rd decile & - & - & - & 0.063 & 0.034 & 0.018 & 0.008 & 0.005 & 0.004 \\
\hline$>4$ th decile & - & - & - & - & 0.192 & 0.091 & 0.034 & 0.019 & 0.018 \\
\hline$>5$ th decile & - & - & - & - & - & 0.049 & 0.005 & 0.003 & 0.008 \\
\hline$>6$ th decile & - & - & - & - & - & - & 0.014 & 0.007 & 0.015 \\
\hline$>7$ th decile & - & - & - & - & - & - & - & 0.028 & 0.050 \\
\hline$>$ 8th decile & - & - & - & - & - & - & - & - & 0.157 \\
\hline mean & 0.331 & 0.335 & 0.347 & 0.358 & 0.364 & 0.366 & 0.367 & 0.368 & 0.370 \\
\hline bandwidth & 661 & 661 & 661 & 661 & 661 & 661 & 661 & 661 & 661 \\
\hline $\mathrm{N}$ & 17,609 & 17,609 & 17,609 & 17,609 & 17,609 & 17,609 & 17,609 & 17,609 & 17,609 \\
\hline
\end{tabular}

Notes: The reform is the introduction of the fiscal rule for municipalities above 1,000 inhabitants in 2013. The top panel reports the local average treatment effect (LATE) of the difference-in-discontinuities molel estimated with a separate local linear regresion for esc treatme variable (reported at the top of each column). The ATE corresponds to $\beta_{6}$ in equation The The bandwidth is selected following Grembi et al. (2016). The deciles refer to the income distribution in each municipality. The middle panel displays p-values for pairwise one-sided tests (estimated by seemingly unrelated regression) whether the effect is higher than the effect on the tax rate at the first to eighth municipal income decile, respectively. In the bottom
panel, the sample mean of the outcome variable, the used bandwidth and the number of observations are shown. Statistical panel, the sample mean of the outcome variable, the used bandwidth and the number of observations are shown. Statistical
significance denoted as: ${ }^{*} p<0.1,{ }^{* *} p<0.05,{ }^{* *} p<0.01$

low-earners (see Table C.1).

As a final test for the effect of introducing the fiscal rule on tax progressivity, we estimate the difference-in-discontinuity design (equation 2) using our four measures of progressivity: the average rate progression, the marginal rate progression, the exemption level (in $€$ ), and a dummy equal to one if the overall income tax schedule is progressive. Table 2 shows that the reform induces an increase in the average (marginal) rate progression of 0.14 (0.16) standard deviations, corresponding to $80 \%$ $(86 \%)$ of the sample mean. The reform also increases the probability of adopting a progressive tax system by six percentage points (Table 2, column 2). This large increase in progressivity is partly driven by the effect on the exemption level, which increases by $600 €$, that is approximately by $67 \%$ of the sample mean (Table 2 , column 4).

Exploiting information on the municipal income distribution, we also estimate the effects on tax revenues levied from taxpayers assigned to different brackets both in aggregate and in per taxpayer terms (see Section 3). In line with the progressive nature of the income tax rate adjustment, our findings suggest that individuals from upper tax brackets contribute more to the extra revenues generated by the reform. 
Table 2: Effect of the reform on progressivity measures

\begin{tabular}{lcccc}
\hline \hline & $(1)$ & $(2)$ & $(3)$ & $(4)$ \\
& average rate progression & progressive tax & marginal rate progression & exemption level \\
\hline LATE & $0.140^{* *}$ & $0.056^{* *}$ & $0.155^{* *}$ & $600^{*}$ \\
& $(0.062)$ & $(0.027)$ & $(0.066)$ & $(316)$ \\
\hline mean & 0.175 & 0.087 & 0.181 & 892 \\
bandwidth & 668 & 650 & 668 & 635 \\
$\mathrm{~N}$ & 17,775 & 17,319 & 17,775 & 16,955 \\
\hline \hline
\end{tabular}

Notes: The reform is the introduction of the fiscal rule for municipalities above 1,000 inhabitants in 2013 . The top panel reports the local average treatment effect (LATE) of the difference-in-discontinuities model estimated with a separate local linear regression for each outcome variable (reported at the top of each column). The LATE corresponds to $\beta_{6}$ in equation 2. The bandwidth is selected following Grembi et al. (2016). The average and marginal rate progressions are estimates of the slope of the average and marginal income tax schedules. Progressive tax is a dummy for whether the municipality has a tax rate which is not uniform. Exemption level is the amount of income (in $€$ ) exempted from the income tax. In the bottom panel, the sample mean of the outcome variable, the used bandwidth and the number of observations are shown. Statistical significance denoted as: ${ }^{*} p<0.1,{ }^{* *} p<0.05,{ }^{* * *} p<0.01$

The average tax increase for a taxpayer in the top income bracket (above 120,000€) amounts to $73 €(47 \%$ relative to the sample mean) which is about an order of magnitude larger than the effect on a taxpayer in the $15,000 €$ to $26,000 €$ bracket. In general, the additional tax revenues per taxpayer induced by the reform are strictly increasing in taxable income (see Table 3).

However, since only few taxpayers have large taxable incomes (on average 15 individuals have taxable incomes above 55,000€), more than half of the extra revenue is levied from tax payers with taxable income between $15,000 €$ and $55,000 €$. Our findings also suggest that individuals with taxable income below 10,000€ (on average $38 \%$ of the total taxpayers) are the only ones to almost entirely escape the tax rate increase. This result is consistent with our previous findings of an increase in exemption levels. 
Table 3: Effect of the reform on income tax revenues by bracket

\begin{tabular}{|c|c|c|c|c|c|c|c|}
\hline & $\begin{array}{c}(1) \\
0 \mathrm{k} €-10 \mathrm{k} €\end{array}$ & $10 \mathrm{k} €-15 \mathrm{k} €$ & $15 \mathrm{k} €-28 \mathrm{k} €$ & $28 \mathrm{k} €-55 \mathrm{k} €$ & $\begin{array}{c}(5) \\
55 \mathrm{k} €-75 \mathrm{k} €\end{array}$ & $\begin{array}{c}(6) \\
75 \mathrm{k} €-120 \mathrm{k} €\end{array}$ & $\begin{array}{c}(7) \\
>120 \mathrm{k} €\end{array}$ \\
\hline LATE & $\begin{array}{c}0.78 \\
(1.02)\end{array}$ & $\begin{array}{l}4.92^{* *} \\
(2.36)\end{array}$ & $\begin{array}{c}7.80^{* *} \\
(3.69)\end{array}$ & $\begin{array}{l}15.88^{* *} \\
(6.25)\end{array}$ & $\begin{array}{c}22.49^{*} \\
(13.53)\end{array}$ & $\begin{array}{l}52.88^{* *} \\
(21.81)\end{array}$ & $\begin{array}{l}73.05^{* *} \\
(30.60)\end{array}$ \\
\hline mean & 18.14 & 47.11 & 76.11 & 129.62 & 177.36 & 195.38 & 154.85 \\
\hline mean \# of taxpayer & 308 & 136 & 241 & 109 & 8 & 5 & 2 \\
\hline bandwidth & 664 & 654 & 665 & 660 & 618 & 479 & 726 \\
\hline $\mathrm{N}$ & 17,684 & 17,444 & 17,709 & 17,587 & 16,544 & 13,163 & 19,180 \\
\hline $\begin{array}{l}\text { total tax revenues } \\
\text { LATE }\end{array}$ & $\begin{array}{c}6.24 \\
(307.52)\end{array}$ & $\begin{array}{c}596.17^{*} \\
(317.41)\end{array}$ & $\begin{array}{l}1561.08^{*} \\
(919.09)\end{array}$ & $\begin{array}{l}1938.44^{* *} \\
(760.57)\end{array}$ & $\begin{array}{l}406.45^{* * *} \\
(149.98)\end{array}$ & $\begin{array}{l}486.49^{* * *} \\
(182.34)\end{array}$ & $\begin{array}{l}627.70^{* * *} \\
(239.48)\end{array}$ \\
\hline $\begin{array}{l}\text { mean } \\
\text { bandwidth } \\
\mathrm{N}\end{array}$ & $\begin{array}{c}4,857.04 \\
700 \\
18,550\end{array}$ & $\begin{array}{c}5,796.83 \\
657 \\
17,508\end{array}$ & $\begin{array}{c}16,824.49 \\
628 \\
16,776\end{array}$ & $\begin{array}{c}12,589.17 \\
647 \\
17,247\end{array}$ & $\begin{array}{c}1,747.59 \\
653 \\
17,408\end{array}$ & $\begin{array}{c}1,566.40 \\
608 \\
16,287\end{array}$ & $\begin{array}{c}1,020.69 \\
688 \\
18,279\end{array}$ \\
\hline
\end{tabular}

\subsection{Sensitivity Checks}

In this section, we discuss the validity of the two major identifying assumptions as described in Section 4. We also perform a number of additional robustness tests with respect to the choice of bandwidth size and polynomial degrees, and a permutation test using placebo thresholds.

First, the local parallel trends assumption states that any difference at the threshold other than the fiscal rule has to be time-constant. To formally test whether the local common trends assumption holds, we use a dynamic version of equation 2 ,

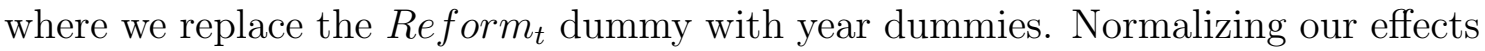
to the pre-reform year of 2012, this allows us to track the local trends before the reform and the dynamic effects after the reform. As Figure 5 shows, there is no significant pre-treatment trend in the bottom tax rate (Panel a), top tax rate (Panel b), the average rate progression (Panel c), or the probability of a progressive tax system (Panel d) ${ }^{25}$ After the reform, there is an immediate significant increase in all variables, but the bottom tax rate. As a further robustness check, we conduct placebo reforms in every pre-reform year of our sample. Specifically, we restrict our sample

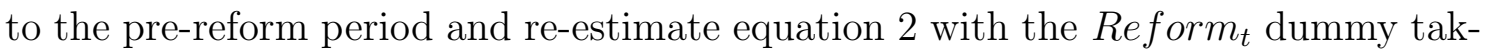

\footnotetext{
${ }^{25}$ This also holds for our other outcomes variables (see Figure D.1).
} 
Figure 5: Dynamic effects of the reform

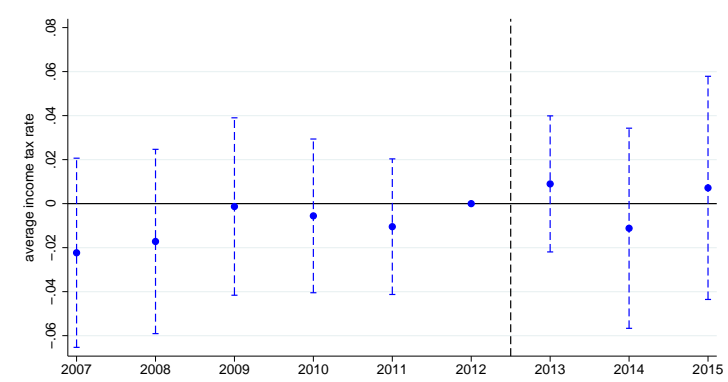

(a) income tax rate at the 1 st decile

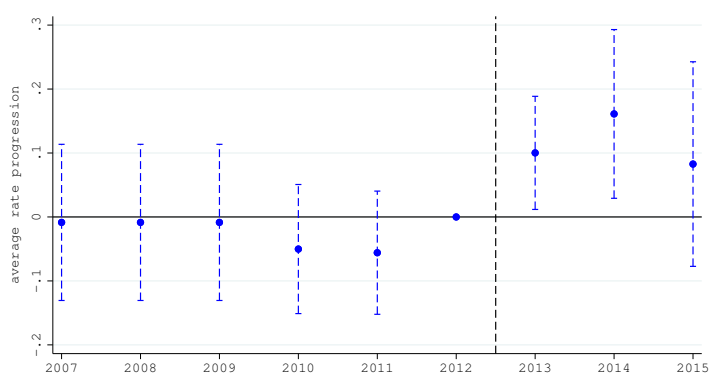

(c) average rate progression

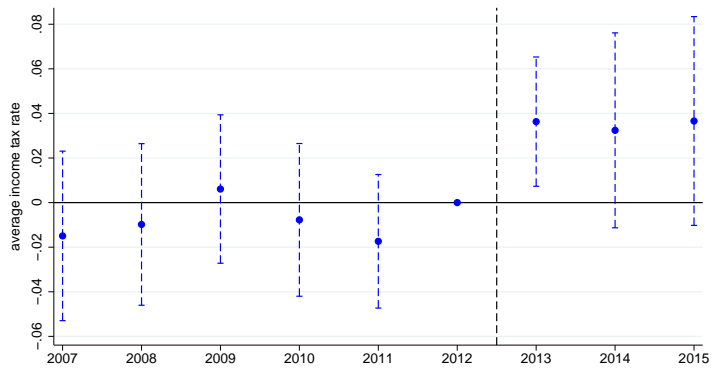

(b) income tax rate at the 9 th decile

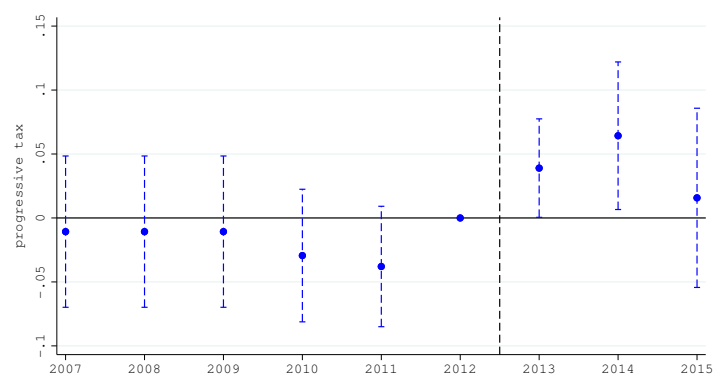

(d) progressive tax

Notes: The reform is the introduction of the fiscal rule for municipalities above 1,000 inhabitants in 2013. Each panel plots estimates from the dynamic model on a different outcome variable, reported underneath each plot. The dynamic model is an extension of the baseline difference-in-discontinuities model that includes year dummies instead of the reform dummy. The bandwidth is selected following Grembi et al. (2016). Each dot is the estimate of the deviation of the outcome variable in the year reported on the horizontal axis relative to the pre-reform year 2012. Dotted bars are $95 \%$ confidence bands.

ing the value 1 from year $t$ onward with $t \in\{2008,2009,2010,2011,2012\}$. If any confounding effect was not time-constant, one would expect to pick up a significant effect by at least one of these placebo reforms. Figure D.2 plots the results of the five placebo estimations as well as that of the baseline results. The results show zero effects for every placebo reform and every tax rate. As expected, the placebo estimates exhibit a constant rather than a monotonically increasing relationship between the estimated tax rate effect and the level of income. Next, we test the continuity assumption by using pre-determined variables as outcomes. Table D.1 shows that none of the 16 variables are significantly influenced by the reform at conventional levels.

Our second identifying assumption is that there is no manipulation of the population numbers in reaction to the reform. In order to test this claim, we present standard McCrary graphs (McCrary, 2008) displaying the density of municipalities 
around the threshold before and after the reform, as well as a "dynamic" McCrary graph, which shows the difference between the density around the threshold before and after the reform (see Asatryan et al., 2017; Grembi et al., 2016). ${ }^{26}$ We do not find evidence of a significant jump in the density of observations at the 1,000 population threshold either before (Figure D.3a) or after (Figure D.3b) the reform. This evidence of no manipulation of population numbers in response to the reform is confirmed by the results of the "dynamic" McCrary test presented in Figure D.4.

Our results are also robust to the selection of different bandwidths. Figure D.5 plots the effect on low- and high-earners for bandwidths ranging from 400 to 1,000. As expected, the standard errors somewhat decrease with larger bandwidth, but the point estimates remain stable. Furthermore, Figure D.6 and Table D.2 show that global polynomial regressions yield very similar results to local linear regressions. Finally, the permutation tests of Figure D.7 re-estimate equation 2 at placebo thresholds and show that our baseline effect on high incomes is larger than any of the placebo estimates.

\section{Mechanisms and Electoral Implications}

We have thus far established that local governments increase tax progressivity in response to exogenous consolidation requirements induced by the fiscal rule. This section first explores heterogeneity in the treatment effects estimated in the previous section. In particular, we study whether the type of tax adjustment is different depending on mayor characteristics, with a special emphasis on her skill level. We then study whether introducing the fiscal rule affects reelection chances of mayors.

\footnotetext{
${ }^{26}$ For the "dynamic" McCrary, we first divide normalized log population size in bins of width 0.01. Then we calculate the change in the total number of observations within each bin from the pre- to the post-reform period. Finally, we fit local polynomial plots using a quadratic degree and a triangular kernel.
} 


\subsection{The Role of High-Skilled Mayors}

Following the literature on competence of politicians and its effects on policy outcomes (see Section 1), we proxy skill with the politician's education level, specifically if she holds a college degree. ${ }^{27}$ As a robustness check, we also use a dummy for being employed in a high-skill profession. About $45 \%$ of the mayors in our sample have a college degree and 38\% work in a high-skill occupation (see Table B.3).

We first test whether highly-educated mayors are driving our progressivity results as measured by both of our progression measures, the exemption level, and a dummy for progressive rather than flat tax systems. Table 4 presents estimates of equation 3 , where the interaction variable $D_{i t}$ is a dummy equal to one if the mayor holds a college degree. It turns out that college-educated mayors drive almost all of the increase in progressivity estimated in our baseline model. Columns 1 shows that mayors with a college education increase the average rate progression by 0.30 standard deviations in response to the fiscal rule, whereas non-college-educated mayors do not change the progressivity of the income tax at all. This result holds when including municipality fixed effects and several other interactions with potential confounders, such as gender, a proxy for electoral competition, political orientation, binding term limits, pre-reform fiscal position, and income structure (see columns 2 to 4 of Table 4). Furthermore, results look very similar when using the skill level of the mayor's occupation as an alternative measure (see columns 5 to 8 of Table 4). Tables C.2, C.3 and C.4 show that this heterogeneous effect also holds for the introduction of progressive tax systems, exemption levels and the marginal rate progression. These results do not mean that low-skilled mayors did not raise local income taxes in response to the reform, but rather that they increased tax rates uniformly (see Figure C.3).

\footnotetext{
${ }^{27}$ In this measurement choice we follow the literature that most often approximates the skill of politicians by their level of education (see, for example, Besley and Reynal-Querol, 2011; Gagliarducci and Nannicini, 2013). Other papers measure the skill of politicians by utilizing data on politicians' experience, pre-office market income, quality (rather than only level) of education or the skill level of their occupation (Bertrand et al., 2019; Besley et al., 2017; Fisman et al., 2015).
} 
Table 4: Differential effect of the reform by mayor's skill

\begin{tabular}{|c|c|c|c|c|c|c|c|c|}
\hline & $\begin{array}{c}(1) \\
\text { average rate } \\
\text { progression }\end{array}$ & $\begin{array}{c}(2) \\
\text { average rate } \\
\text { progression }\end{array}$ & $\begin{array}{c}(3) \\
\text { average rate } \\
\text { progression }\end{array}$ & $\begin{array}{c}(4) \\
\text { average rate } \\
\text { progression }\end{array}$ & $\begin{array}{c}(5) \\
\text { average rate } \\
\text { progression }\end{array}$ & $\begin{array}{c}(6) \\
\text { average rate } \\
\text { progression }\end{array}$ & $\begin{array}{c}(7) \\
\text { average rate } \\
\text { progression }\end{array}$ & $\begin{array}{c}(8) \\
\text { average rate } \\
\text { progression }\end{array}$ \\
\hline LATE & $\begin{array}{c}0.012 \\
(0.082)\end{array}$ & $\begin{array}{c}0.013 \\
(0.082)\end{array}$ & $\begin{array}{l}-0.004 \\
(0.081)\end{array}$ & $\begin{array}{l}-0.016 \\
(0.167)\end{array}$ & $\begin{array}{c}0.010 \\
(0.076)\end{array}$ & $\begin{array}{c}0.015 \\
(0.077)\end{array}$ & $\begin{array}{l}-0.009 \\
(0.076)\end{array}$ & $\begin{array}{l}-0.010 \\
(0.162)\end{array}$ \\
\hline LATE $x$ college degree & $\begin{array}{c}0.298^{* *} \\
(0.120)\end{array}$ & $\begin{array}{c}0.293^{* *} \\
(0.119)\end{array}$ & $\begin{array}{l}0.231^{* *} \\
(0.106)\end{array}$ & $\begin{array}{l}0.229^{* * *} \\
(0.108)\end{array}$ & & & & \\
\hline LATE $\mathrm{x}$ high-skill job & & & & & $\begin{array}{l}0.359^{* * *} \\
(0.133)\end{array}$ & $\begin{array}{l}0.339^{* *} \\
(0.133)\end{array}$ & $\begin{array}{l}0.294^{* *} \\
(0.120)\end{array}$ & $\begin{array}{l}0.281^{* *} \\
(0.119)\end{array}$ \\
\hline LATE $\mathrm{x}$ female mayor & & & & $\begin{array}{c}0.069 \\
(0.163)\end{array}$ & & & & $\begin{array}{c}0.076 \\
(0.168)\end{array}$ \\
\hline LATE $x$ left-wing mayor & & & & $\begin{array}{c}0.025 \\
(0.154)\end{array}$ & & & & $\begin{array}{l}0.020 \\
(0.155)\end{array}$ \\
\hline LATE $\mathrm{x}$ right-wing mayor & & & & $\begin{array}{l}-0.360 \\
(0.297)\end{array}$ & & & & $\begin{array}{l}-0.344 \\
(0.300)\end{array}$ \\
\hline LATE $\mathrm{x}$ centrist mayor & & & & $\begin{array}{l}-0.489 \\
(0.342)\end{array}$ & & & & $\begin{array}{l}-0.605 \\
(0.388)\end{array}$ \\
\hline LATE $x$ low win margin & & & & $\begin{array}{c}0.097 \\
(0.114)\end{array}$ & & & & $\begin{array}{c}0.088 \\
(0.117)\end{array}$ \\
\hline LATE $x$ term limit & & & & $\begin{array}{l}-0.041 \\
(0.100)\end{array}$ & & & & $\begin{array}{l}-0.060 \\
(0.101)\end{array}$ \\
\hline LATE $\mathrm{x}$ high pre-reform deficit & & & & $\begin{array}{c}0.133 \\
(0.132)\end{array}$ & & & & $\begin{array}{c}0.129 \\
(0.132)\end{array}$ \\
\hline LATE $x$ low top income share & & & & $\begin{array}{l}-0.177 \\
(0.132)\end{array}$ & & & & $\begin{array}{l}-0.174 \\
(0.132)\end{array}$ \\
\hline controls & & yes & yes & yes & & yes & yes & yes \\
\hline municipality FE & & & yes & yes & & & yes & yes \\
\hline $\begin{array}{l}\text { mean } \\
\text { bandwidth }\end{array}$ & $\begin{array}{c}0.176 \\
668\end{array}$ & $\begin{array}{c}0.178 \\
668\end{array}$ & $\begin{array}{c}0.178 \\
668\end{array}$ & $\begin{array}{c}0.178 \\
668\end{array}$ & $\begin{array}{c}0.173 \\
668\end{array}$ & $\begin{array}{c}0.177 \\
668\end{array}$ & $\begin{array}{c}0.177 \\
668\end{array}$ & $\begin{array}{c}0.177 \\
668\end{array}$ \\
\hline $\mathrm{N}$ & 17,378 & 17,092 & 17,092 & 17,092 & 17,292 & 16,741 & 16,741 & 16,741 \\
\hline
\end{tabular}

The heterogenous effects estimated so far in this section using equation 3 do not have a causal interpretation because mayors' education is not assigned at random to different municipalities. As such, unobserved factors at the mayor or municipal-level might induce omitted variable bias and thus drive the estimated heterogeneity. To tackle this issue, we focus on mixed elections, in which the winner and runner-up have different education levels. Using this sample, we estimate the heterogeneous effect at the election threshold by interacting all variables with the vote margin between the two candidates. In other words, we combine equations 3 and 4 .

This empirical strategy accounts for any municipal level unobserved differences between municipalities with or without a college-educated mayor, such as unobserved preference for redistribution. However, it does not account for mayoral characteristics correlated with education. We thus start by testing whether any characteristic besides the education level of the mayor changes discontinuously at the election threshold. Table D.3 in the Appendix shows that out of 16 variables only the mayor's gender varies significantly between college-educated and non-college mayors. Educated mayors are more likely to be female. Since there was no effect 
Table 5: Differential effect of the reform by mayor's skill: mixed election RD

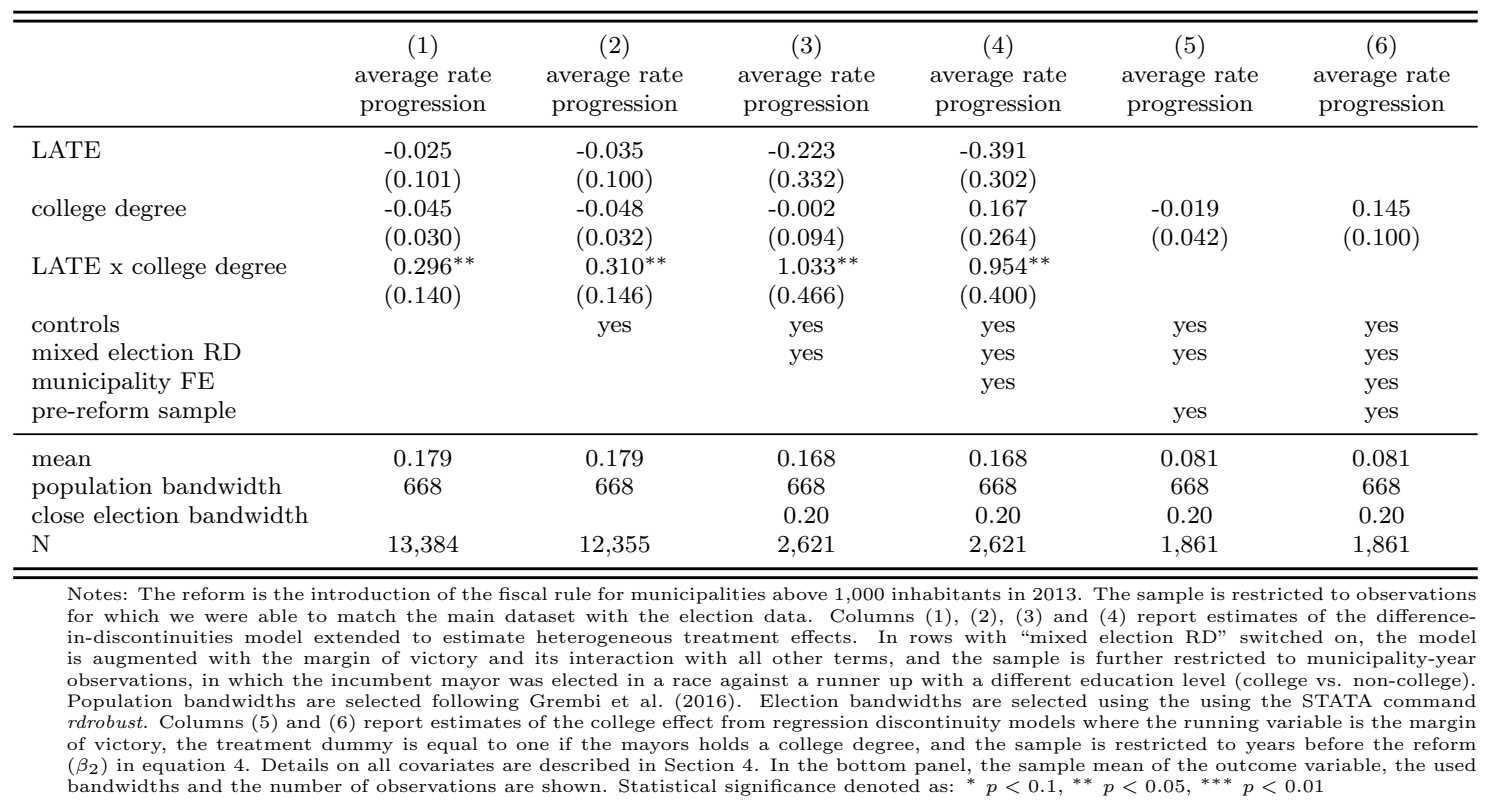

of gender in Table 4 and we control for gender in all of our previous specifications, we do not regard this imbalance as a serious threat to our empirical strategy. We include all these mayoral characteristics as control variables in the regression models that combine our baseline difference-in-discontinuity with close elections. Furthermore, Figure D.8 shows that there is no discontinuity in the density of the margin of victory.

Estimates from these models are shown in Table 5 for the average rate progression. Columns 1 and 2 show that the heterogeneous effect estimated on the sample of municipalities, in which the mayor was elected in a mixed election, is very similar to the estimates obtained on the full sample in Table 4. Next, we present the results of equation 3 interacted with the vote margin between the college-educated and non-college-educated candidate in columns 3 and 4 . The result confirms our previous findings. The reform-induced increase in progressivity is driven entirely by municipalities ruled by college-educated mayors. This result also holds when using other measures of progressivity (see Tables C.5, C.6 and C.7) or varying the bandwidth of the close election RD (see Table D.9).

The findings in this section have established that college-educated mayors re- 
act to the introduction of the fiscal rule by increasing income taxes progressively, while other mayors increase taxes uniformly. We can rule out that college-educated mayors favor more tax progressivity in general. Using a simple regression discontinuity design based on close elections (equation 4) and restricting our attention to years before the introduction of the fiscal rule, we do not find any evidence that municipalities ruled by college-educated mayors have more progressive tax systems (see columns 5 and 6 of Table 5 ).

\subsection{Political Costs of Austerity}

We now test whether the introduction of the fiscal rule was associated with a political cost for the incumbent mayor. In particular, we estimate the baseline differences-indiscontinuities model (equation 2) with the reelection and rerun dummies as outcome variables (see Section 3 for a detailed description of these variables). Note that the mayor's skill level is a predetermined characteristic with respect to the reform in 2013, since we only consider the first election after the reform.

Based on a standard median-voter model, progressive taxation should be less costly than uniform taxation, since only a minority of rich households are taxed at a higher rate (Bierbrauer and Boyer, 2018). Additionally, in our context of austerity, compensatory arguments behind progressive taxes (Scheve and Stasavage, 2016) would suggest to shift the tax increase away from the poorest households if the fiscal austerity imposed by the national government is perceived as unfair towards the poor.

The near zero point estimate in column 1 of Table 6 suggests that there is no evidence of political costs for the average incumbent. However, this average effect hides interesting heterogeneity. When allowing for heterogeneity in mayoral education in columns 2 and 3, we find that mayors without a college degree experienced a severe drop of 30 to 37 percentage points in reelection probability, while educated mayors do not undergo these costs at all. Both point estimates are significant at 
Table 6: Effects of the reform on mayors' reelection odds

\begin{tabular}{|c|c|c|c|c|c|c|c|c|}
\hline & $\begin{array}{l}(1) \\
\text { reelection }\end{array}$ & $\begin{array}{c}(2) \\
\text { reelection }\end{array}$ & $\begin{array}{c}(3) \\
\text { reelection }\end{array}$ & $\begin{array}{c}(4) \\
\text { reelection }\end{array}$ & $\begin{array}{l}(5) \\
\text { re-run }\end{array}$ & $\begin{array}{l}(6) \\
\text { re-run }\end{array}$ & $\begin{array}{l}(7) \\
\text { re-run }\end{array}$ & $\begin{array}{l}(8) \\
\text { re-run }\end{array}$ \\
\hline LATE & $\begin{array}{l}-0.004 \\
(0.059)\end{array}$ & $\begin{array}{l}-0.297^{* *} \\
(0.142)\end{array}$ & $\begin{array}{l}-0.370^{* * *} \\
(0.132)\end{array}$ & & $\begin{array}{l}-0.090 \\
(0.060)\end{array}$ & $\begin{array}{l}-0.085 \\
(0.111)\end{array}$ & $\begin{array}{l}-0.138 \\
(0.111)\end{array}$ & \\
\hline college degree & & $\begin{array}{l}-0.073 \\
(0.226)\end{array}$ & $\begin{array}{l}-0.036 \\
(0.218)\end{array}$ & $\begin{array}{l}-0.025 \\
(0.021)\end{array}$ & & $\begin{array}{c}0.209^{*} \\
(0.119)\end{array}$ & $\begin{array}{c}0.180 \\
(0.118)\end{array}$ & $\begin{array}{l}-0.019 \\
(0.022)\end{array}$ \\
\hline LATE $x$ college degree & & $\begin{array}{c}0.472^{* *} \\
(0.235)\end{array}$ & $\begin{array}{c}0.471^{* *} \\
(0.230)\end{array}$ & & & $\begin{array}{c}0.105 \\
(0.190)\end{array}$ & $\begin{array}{c}0.102 \\
(0.193)\end{array}$ & \\
\hline municipality FE & & yes & yes & & & yes & yes & \\
\hline controls & & & yes & yes & & & yes & yes \\
\hline pre-reform sample & & & & yes & & & & yes \\
\hline mean & 0.832 & 0.832 & 0.834 & 0.833 & 0.607 & 0.607 & 0.607 & 0.594 \\
\hline bandwidth & 1059 & 1059 & 1059 & 1059 & 1088 & 1088 & 1088 & 1088 \\
\hline $\mathrm{N}$ & 2,833 & 2,833 & 2,745 & 1,410 & 4,271 & 4,271 & 4,135 & 2,357 \\
\hline
\end{tabular}

conventional levels. ${ }^{28}$ The probability of running for office again drops on average, driven by mayors without a college degree, but these effects are not significant at conventional levels (see columns 5 to 7 of Table 6 ). This is consistent with noncollege mayors also self-selecting out of office, but our results seem to be mainly driven by voter selection. Again, results point in the same direction when using the mayor's occupation as an alternative measure of skill (see Table C.8).

Taken together, our findings suggest that more skilled politicians have avoided the political cost of austerity by designing a fiscal adjustment based on progressive taxation. Although we can not provide a direct causal link from increased progressivity to higher reelection odds, we can rule out that skilled politicians have higher re-election odds in general. Using a simple regression discontinuity design based on close elections (equation 4) and restricting our attention to years before the introduction of the fiscal rule, we do not find any evidence that college-educated mayors are more likely to be reelected or to run again (see columns 4 and 8 of Table 6). Any alternative explanation for our findings must thus explain why the introduction of the DSP differentially increased the skilled mayors' re-election odds during our sample period. Existing evidence on the lifting of the DSP in 2001, when implementing local tax progressivity was not yet feasible, actually shows that the fiscal

\footnotetext{
${ }^{28}$ The effect is very stable when varying the bandwidths (see Figure D.10).
} 
rule decreased the mayors' education level in that occasion (Gamalerio, 2019). ${ }^{29}$

\subsection{Alternative Channels of Adjustment}

As discussed in Section 2, the local income tax is not the only policy instrument that Italian municipalities can use to comply with the fiscal rule. To shed more light on the full adjustment behavior of affected municipalities, we estimate the effects of the fiscal rule on all revenue and spending categories using our baseline model (equation 2) and municipal account data.

In line with our findings on the local income tax rates, revenues from the local income tax increase significantly (see column 1 of Table 7 ). We do not find significant increases in any of the other revenue categories: property tax, trash tax, other taxes or fees, sales, loans, and other revenues (see columns 2 to 7 of Table 7 ). ${ }^{30}$ We also do not find any significant effects of the reform on capital nor current expenditures (see columns 8 to 10 of Table 7). Placebo tests for both expenditure and revenue categories show that treatment and control municipalities were on parallel trends before the reform (see Table D.4). To test whether the average expenditure effect is masking heterogeneous effects across different categories of expenditures, we estimate the impact of the fiscal rule on each one separately. Looking at various expenditure items rather than just at social transfers only allows us to take into account potential in-kind transfers which have been shown to matter for inequality (Aaberge et al., 2018). Out of the twelve subcategories of municipal expenditures, only tourism spending is reduced significantly with the other point estimates fluctuating around zero (see Figure C.4). Importantly, the two categories perhaps most associated with redistribution, social and education spending, are hardly affected,

\footnotetext{
${ }^{29}$ According to the author's interpretation, skilled politicians avoid entering the political arena when their discretion over fiscal policy is constrained. The difference with our results can thus be explained by the additional policy instrument of differentiated local tax rates, which was not available to mayors in 2001. Furthermore, our results seem to be driven mainly by voters' demand rather than purely by the supply of politicians.

${ }^{30}$ Consistent with these results, we also do not find any effect on property tax rates for either main or other dwellings, or deduction amounts (see Table C.9). We only use the years 2012 to 2015 for these regressions since the introduction of the Imposta Municipale Propria.
} 
Table 7: Effect of the reform on municipal budget accounts

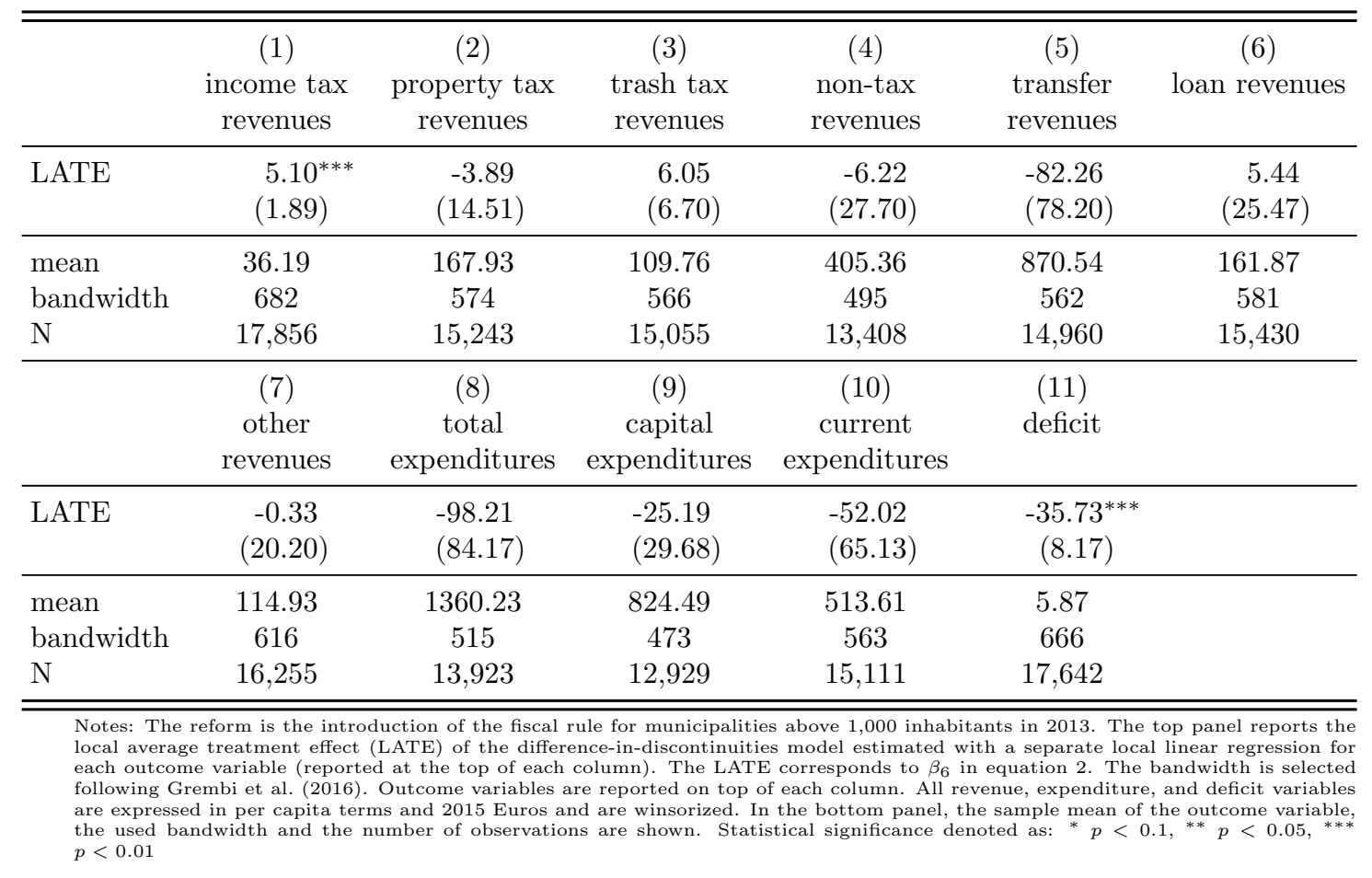

with the point estimate of social spending even being positive. Still, this null result might hide heterogeneity between high- and low-skilled mayors that could also explain their differential political outcomes. To test this hypothesis, we estimate the heterogeneous treatment effect of high-skilled mayors for all spending categories. Table C.10 shows that there is no significant difference in any of the spending items. We conclude that the redistributive effect of more progressive income taxes is unlikely to be offset by adjustments on the expenditure side of local budgets.

Finally, we investigate the effects of the introduction of the fiscal rule on municipal deficits. As one can see in column 11 of Table 7, we find that the official deficit is reduced by $36 €$ per capita (significant at the $1 \%$ level). Hence, it appears that the fiscal rule was effective in terms of reducing municipal deficits.

\section{Conclusion}

This paper provides the first quasi-experimental evidence that governments try to ease the potential distributional implications of austerity by favoring the relatively 
poor through more progressive income tax policies. Additional evidence suggests that this strategy is used by more competent mayors and is subsequently rewarded in the polls.

These results are consistent with the view that progressive taxation is preferable to uniform taxation for the median voter. We believe that our evidence is particularly relevant for austerity episodes induced by external factors (e.g., resulting from the imposition of budget constraints from a higher layer of government, or being due to inter-regional spillovers in economic crisis), which can be seen as unfair from the perspective of the local population. Our study suggests that governments can tune their fiscal reform packages to mitigate the distributional consequences of austerity, as recommended by IMF (2014), and that this adjustment strategy allows them to improve their reelection odds.

Our findings are relevant for policy makers in countries subject to fiscal constraints, but whose public opinion is growing critical of austerity policies. Although our evidence from small Italian towns cannot be immediately extended to other settings, our cross-country evidence on the positive relation between austerity and top income tax rates adds to the external validity of our results. 


\section{References}

Aaberge, Rolf, Lasse Eika, Audun Langørgen, and Magne Mogstad (2018). "Local governments, in-kind transfers, and economic inequality". Journal of Public Economics.

Alesina, Alberto, Dorian Carloni, and Giampaolo Lecce (2012). "The electoral consequences of large fiscal adjustments". NBER Chapters, 531-570.

Alesina, Alberto, Carlo Favero, and Francesco Giavazzi (2019). Austerity: When it works and when it doesn't. Princeton University Press.

Arias, Eric and David Stasavage (2019). "How large are the political costs of fiscal austerity?" The Journal of Politics 81 (4), 1517-1522.

Asatryan, Zareh, Thushyanthan Baskaran, Theocharis Grigoriadis, and Friedrich Heinemann (2017). "Direct democracy and local public finances under cooperative federalism". The Scandinavian Journal of Economics 119 (3), 801-820.

Asatryan, Zareh, Cesar Castellon, and Thomas Stratmann (2018). "Balanced budget rules and fiscal outcomes: Evidence from historical constitutions". Journal of Public Economics 167, 105-119.

Avram, Silvia, Francesco Figari, Chrysa Leventi, Horacio Levy, Jekaterina Navicke, Manos Matsaganis, Eva Militaru, Alari Paulus, Olga Rastringina, and Holly Sutherland (2013). "The distributional effects of fiscal consolidation in nine countries". Working Paper (EM2/13).

Ball, Laurence, Davide Furceri, Daniel Leigh, and Prakash Loungani (2013). The distributional effects of fiscal consolidation. 13-151. International Monetary Fund.

Baltrunaite, Audinga, Alessandra Casarico, Paola Profeta, and Giulia Savio (2018). "Let the voters choose women". Working Paper. 
Bansak, Kirk, Michael M Bechtel, and Yotam Margalit (2020). "Why Austerity? The Mass Politics of a Contested Policy". Working paper.

Barnes, Lucy and Timothy Hicks (2018). "Making austerity popular: the media and mass attitudes toward fiscal policy". American Journal of Political Science 62 (2), 340-354.

Baskaran, Thushyanthan and Zohal Hessami (2018). "Does the election of a female leader clear the way for more women in politics?" American Economic Journal: Economic Policy 10 (3), 95-121.

Becker, Sascha, Peter Egger, and Maximilian von Ehrlich (2013). "Absorptive capacity and the growth and investment effects of regional transfers: A regression discontinuity design with heterogeneous treatment effects". American Economic Journal: Economic Policy 5 (4), 29-77.

Bernhardt, Dan, Peter Buisseret, and Sinem Hidir (2020). "The Race to the Base". American Economic Review 110 (3), 922-42.

Bertrand, Marianne, Robin Burgess, Arunish Chawla, and Guo Xu (2019). "The glittering prizes: Career incentives and bureaucrat performance". The Review of Economic Studies, forthcoming.

Besley, Timothy and Marta Reynal-Querol (2011). "Do democracies select more educated leaders?" American Political Science Review 105 (3), 552-566.

Besley, Timothy, Jose Montalvo, and Marta Reynal-Querol (2011). "Do educated leaders matter?" The Economic Journal 121 (554), 205-227.

Besley, Timothy, Olle Folke, Torsten Persson, and Johanna Rickne (2017). "Gender quotas and the crisis of the mediocre man: Theory and evidence from Sweden". American Economic Review 107 (8), 2204-42. 
Bierbrauer, Felix and Pierre Boyer (2013). "Political competition and Mirrleesian income taxation: A first pass". Journal of Public Economics 103, 1-14.

— (2018). "Politically feasible reforms of non-linear tax systems". CEPR Discussion Paper No. 13059.

Bierbrauer, Felix, Pierre Boyer, and Anasuya Raj (2018). "On the political economy of the income-tax threshold". Mimeo.

Blesse, Sebastian, Massimo Bordignon, Pierre Boyer, Piergiorgio Carapella, Friedrich Heinemann, Eckhard Janeba, and Anasuya Raj (2019). "United we stand? Survey results on the views of French, German and Italian parliamentarians on EU and EMU reforms". ZEW Policy Brief.

Blyth, Mark (2013). Austerity: The history of a dangerous idea. New York: Oxford University Press.

Brender, Adi and Allan Drazen (2008). "How do budget deficits and economic growth affect reelection prospects? Evidence from a large panel of countries". American Economic Review 98 (5), 2203-20.

Calonico, Sebastian, Matias Cattaneo, and Rocio Titiunik (2014). "Robust datadriven inference in the regression-discontinuity design". Stata Journal 14 (4), 909-946.

— (2015). "Optimal data-driven regression discontinuity plots". Journal of the American Statistical Association 110 (512), 1753-1769.

Calonico, Sebastian, Matias Cattaneo, Max Farrell, and Rocio Titiunik (2017). "rdrobust: Software for regression-discontinuity designs". The Stata Journal $17(2), 372-404$. 
Chen, Sophia, Deniz Igan, and Victoria Wenxin Xie (2019). "Sharing the burden: Household-level evidence on fiscal consolidation in the European Union". IMF Working Paper.

Chiades, Paolo and Vanni Mengotto (2015). "Il calo degli investimenti nei Comuni tra Patto di stabilitÂ interno e carenza di risorse". IT. ECONOMIA PUBBLICA (2), 5-44.

Combes, Jean-Louis, Xavier Debrun, Alexandru Minea, and René Tapsoba (2018). "Inflation Targeting, Fiscal Rules and the Policy Mix: Cross-effects and Interactions". The Economic Journal 128 (615), 2755-2784.

Cooper, Vickie and David Whyte (2017). The violence of austerity. Pluto Press.

Coviello, Decio, Immacolata Marino, Tommaso Nannicini, and Nicola Persico (2019). "Effect of a Fiscal Demand Shock on Firm Investment". Working Paper.

Dal Bo, Ernesto, Frederico Finan, Olle Folke, Torsten Persson, and Johanna Rickne (2018). "Economic losers and political winners: Sweden's radical right". Working Paper.

Daniele, Gianmarco, Tommaso Giommoni, and Tommaso Orlando (2019). "Fighting corruption with fiscal rules". Mimeo.

Dovis, Alessandro and Rishabh Kirpalani (2020). "Fiscal rules, bailouts, and reputation in federal governments". American Economic Review 110 (3), 860-88.

Eliason, Paul and Byron Lutz (2018). "Can fiscal rules constrain the size of government? An analysis of the crown jewel of tax and expenditure limitations". Journal of Public Economics 166, 115-144. 
Eyraud, Luc, Xavier Debrun, Andrew Hodge, Victor Duarte Lledo, and Catherine Pattillo (2018). Second-generation fiscal rules: Balancing simplicity, flexibility, and enforceability. 04. International Monetary Fund Discussion Note.

Ferraz, Claudio, Dirk Foremny, and Juan Francisco Santini (2018). "Revenue shocks and fiscal capacity: Evidence from Brazil". Mimeo.

Fetzer, Thiemo (2019). "Did austerity cause Brexit?" American Economic Review 109 (11), 3849-3886.

Fisman, Raymond, Nikolaj Harmon, Emir Kamenica, and Inger Munk (2015). "Labor supply of politicians". Journal of the European Economic Association 13 (5), 871-905.

Gagliarducci, Stefano and Tommaso Nannicini (2013). "Do better paid politicians perform better? Disentangling incentives from selection". Journal of the European Economic Association 11 (2), 369-398.

Gamalerio, Matteo (2019). "Fiscal rules and the selection of politicians: Evidence from Italian municipalities". Working Paper.

Giommoni, Tommaso (2019). "Does progressivity always lead to progress? The impact of fiscal flexibility on tax manipulation". Working Paper.

Grembi, Veronica, Tommaso Nannicini, and Ugo Troiano (2016). "Do fiscal rules matter?" American Economic Journal: Applied Economics 8 (3), 1-30.

Heimberger, Philipp (2018). "The dynamic effects of fiscal consolidation episodes on income inequality: Evidence for 17 OECD countries over 1978-2013". Empirica, $1-29$. 
Heinemann, Friedrich, Marc-Daniel Moessinger, and Mustafa Yeter (2018). "Do fiscal rules constrain fiscal policy? A meta-regression-analysis". European Journal of Political Economy 51, 69-92.

Hübscher, Evelyne, Thomas Sattler, and Markus Wagner (2018). "Voter Responses to Fiscal Austerity". Available at SSRN 3289341.

IMF (2014). "Fiscal policy and income inequality". IMF Policy Paper.

ISTAT (2013). "Classificazione delle professioni". Tech. rep. https://www.istat.it/it/archivio/18132.

Karamessini, Maria and Jill Rubery (2013). Women and austerity: The economic crisis and the future for gender equality. Routledge.

Marattin, Luigi, Tommaso Nannicini, and Francesco Porcelli (2019). "Revenue vs expenditure based fiscal consolidation: The pass-trough from federal cuts to local taxes". Working Paper.

Martinez-Bravo, Monica (2017). "The local political economy effects of school construction in Indonesia". American Economic Journal: Applied Economics 9 (2), $256-89$.

McCrary, Justin (2008). "Manipulation of the running variable in the regression discontinuity design: A density test". Journal of Econometrics 142 (2), 698714.

Mendoza, Kerry-Anne (2014). Austerity: The demolition of the welfare state and the rise of the zombie economy. New Internationalist.

Messina, Giovanna and Marco Savegnago (2014). "A Prova Di Acronimo: I Tributi Locali Sulla Casa in Italia (Beyond the Acronyms: Local Property Taxation in Italy)". Bank of Italy Occasional Paper (250). 
Messina, Giovanna, Marco Savegnago, and Andrea Sechi (2018). Il prelievo locale sui rifiuti in Italia: benefit tax o imposta patrimoniale (occulta)? Banca d'Italia.

Passarelli, Francesco and Guido Tabellini (2017). "Emotions and political unrest". Journal of Political Economy 125 (3), 903-946.

Paulus, Alari, Francesco Figari, and Holly Sutherland (2016). "The design of fiscal consolidation measures in the European Union: Distributional effects and implications for macro-economic recovery". Oxford Economic Papers 69 (3), $632-654$

Peltzman, Sam (1992). "Voters as fiscal conservatives". The Quarterly Journal of Economics 107 (2), 327-361.

Persson, Torsten and Guido Enrico Tabellini (2002). Political economics: Explaining economic policy. MIT press.

Peter, Klara Sabirianova, Steve Buttrick, and Denvil Duncan (2010). "Global reform of personal income taxation 1981-2005: Evidence from 189 countries". National Tax Journal 63 (3), 447.

Phillips-Fein, Kim (2013). Fear City: New York's Fiscal Crisis and the Rise of Austerity Politics. Metropolitan Books.

Ponticelli, Jacopo and Hans-Joachim Voth (2019). "Austerity and anarchy: Budget cuts and social unrest in Europe, 1919-2008". Journal of Comparative Economics.

Repetto, Luca (2018). "Political budget cycles with informed voters: Evidence from Italy". The Economic Journal 128 (616), 3320-3353. 
Rubolino, Enrico and Daniel Waldenström (2019). "Trends and gradients in top tax elasticities: Cross-country evidence, 1900-2014". International Tax and Public Finance 26 (3), 457-485.

Scheve, Kenneth and David Stasavage (2010). "The conscription of wealth: Mass warfare and the demand for progressive taxation". International Organization $64(4), 529-561$.

(2012). "Democracy, war, and wealth: Lessons from two centuries of inheritance taxation". American Political Science Review 106 (1), 81-102.

(2016). Taxing the rich: A history of fiscal fairness in the United States and Europe. Princeton University Press.

Stuckler, David and Sanjay Basu (2013). The body economic: Why austerity kills. Basic Books.

SWG (2017). Fiscal Compact - Uno stop netto e secco alle politiche di austerity. http://www.swg.it/politicapp?id=afri.

Talving, Liisa (2017). "The electoral consequences of austerity: Economic policy voting in Europe in times of crisis". West European Politics 40 (3), 560-583.

Varoufakis, Yanis (2016). And the weak suffer what they must?: Europe, austerity and the threat to global stability. Random House.

Vincent, Santiago Perez (2017). "A few signatures matter: Candidacy requirements in Italian local elections". Mimeo.

Woo, Jaejoon, Elva Bova, Tidiane Kinda, and Sophia Zhang (2013). "Distributional consequences of fiscal consolidation and the role of fiscal policy: What do the data say?" Tech. rep. 13-195. IMF. 


\section{Online Appendix (not for publication)}

\section{A Country-level Analysis}

\section{Table A.1: Cyclically adjusted primary balance and tax rates}

\begin{tabular}{lcc}
\hline \hline & $(1)$ & $(2)$ \\
& tax rate at mean incomes & top tax rate \\
\hline cyclically adjusted primary balance & 0.071 & $0.615^{* *}$ \\
(in \% of potential GDP) & $(0.089)$ & $(0.291)$ \\
country FE & yes & yes \\
year FE & yes & yes \\
controls & yes & yes \\
\hline mean & 25.533 & 41.749 \\
$\mathrm{~N}$ & 806 & 806 \\
\hline \hline
\end{tabular}

Notes: ${ }^{*} p<0.1,{ }^{* *} p<0.05,{ }^{* * *} p<0.01$; Robust standard errors are clustered at the country level. This table shows estimates from the regression $y_{i t}=\gamma_{i}+\lambda_{t}+\beta c a p b_{i t}+$ $\delta X_{i t}+\epsilon_{i t}$, where $y_{i t}$ is either the tax rate at mean incomes (column 1) or at top incomes (column 2), $c a p b_{i t}$ is the cyclically adjusted primary balance in percent of potential GDP, $X_{i t}$ includes log GDP per capita and log population as control variables, $\gamma_{i}$ are country fixed effects and $\lambda_{t}$ are year fixed effects. Top tax rates are drawn from Rubolino and Waldenström (2019), tax rates at mean incomes are from Peter et al. (2010), supplemented by tax data from the OECD. The budget data comes from IMF DataMapper. Our sample consists of 40 countries (Argentina, Australia, Austria, Belgium, Canada, Chile, China, Czech Republic, Denmark, Estonia, Finland, France, Germany, Greece, Hungary, Iceland, India, Ireland, Israel, Italy, Japan, Latvia, Lithuania, Luxembourg, Malaysia, Mexico, Netherlands, New Zealand, Norway, Poland, Portugal, Slovakia, Slovenia, South Korea, Spain, Sweden, Switzerland, Turkey, the United Kingdom and the United States) over the period 1990-2017. 


\section{B Institutions and Summary Statistics}

Table B.1: Fiscal rule details

\begin{tabular}{lllll}
\hline \hline year & target & target function of & reference period & pop. threshold \\
\hline 2007 & Saldo Finanziario & expenditures & $2003-05$ & 3,000 \\
2008 & Saldo Finanziario & expenditures & $2003-05$ & 3,000 \\
2009 & Saldo Finanziario & Saldo Finanziario & 2007 & 5,000 \\
2010 & Saldo Finanziario & Saldo Finanziario & 2007 & 5,000 \\
2011 & Saldo Finanziario & current expenditures & $2006-08$ & 5,000 \\
2012 & Saldo Finanziario & current expenditures & $2006-08$ & 5,000 \\
2013 & Saldo Finanziario & current expenditures & $2007-09$ & 1,000 \\
2014 & Saldo Finanziario & current expenditures & $2009-11$ & 1,000 \\
2015 & Saldo Finanziario & current expenditures & $2010-12$ & 1,000 \\
\hline \hline
\end{tabular}

Notes: The table reports details on the target of the fiscal rule for different years. Saldo Finanziario is defined as the difference between expenditures and revenues, net of repayment of outstanding debt and of lending. The target Saldo Finanziario must be below a target defined as a function of some budget account items measured in a reference period. 
Table B.2: Population cutoffs in Italian municipalities before and after 2013

\begin{tabular}{|c|c|c|c|c|c|c|c|c|c|c|c|c|}
\hline \multirow[t]{2}{*}{ population } & \multicolumn{2}{|c|}{ mayor's wage } & \multicolumn{2}{|c|}{$\begin{array}{l}\text { wage of ex. } \\
\text { committee }\end{array}$} & \multicolumn{2}{|c|}{$\begin{array}{c}\text { size of city } \\
\text { council }\end{array}$} & \multicolumn{2}{|c|}{$\begin{array}{l}\text { signature } \\
\text { requirement }\end{array}$} & \multicolumn{2}{|c|}{ gender quota } & \multicolumn{2}{|c|}{ fiscal rule } \\
\hline & before & after & before & after & before & after & before & after & before & after & before & after \\
\hline below 1,000 & 1,291 & 1,291 & $15 \%$ & $15 \%$ & 12 & 12 & 0 & 0 & no & no & no & no \\
\hline $1,000-2,000$ & 1,446 & 1,446 & $20 \%$ & $20 \%$ & 12 & 12 & 30 & 30 & no & no & no & yes \\
\hline $2,000-3,000$ & 1,446 & 1,446 & $20 \%$ & $20 \%$ & 12 & 12 & 40 & 40 & no & no & no & yes \\
\hline $3,000-5,000$ & 2,169 & 2,169 & $20 \%$ & $20 \%$ & 16 & 16 & 40 & 40 & no & no & no & yes \\
\hline $5,000-10,000$ & 2,789 & 2,789 & $50 \%$ & $50 \%$ & 16 & 16 & 80 & 80 & no & yes & yes & yes \\
\hline
\end{tabular}

Source: Grembi et al. 2016, Vincent 2017, Baltrunaite et al. 2018. Notes: Policies varying at different legislative thresholds in the period 2007 - 2015. The before columns indicate the situation from 2007 to 2012 , while the after columns refer to period from 2013 to 2015. Discontinuities at thresholds over 5,000 inhabitants are omitted. Population is the number of resident inhabitants. The wage of both the mayor and the executive committee refer to monthly gross wages and the latter is expressed as a percentage of the former. Size of city council is the number of seats in the city council. The signature requirement refers to number of signatures a candidate for mayor requires to be allowed to run, while the gender quota refers to candidate lists and new a system of double preference voting conditional on gender.

Figure B.1: Municipal revenues over time

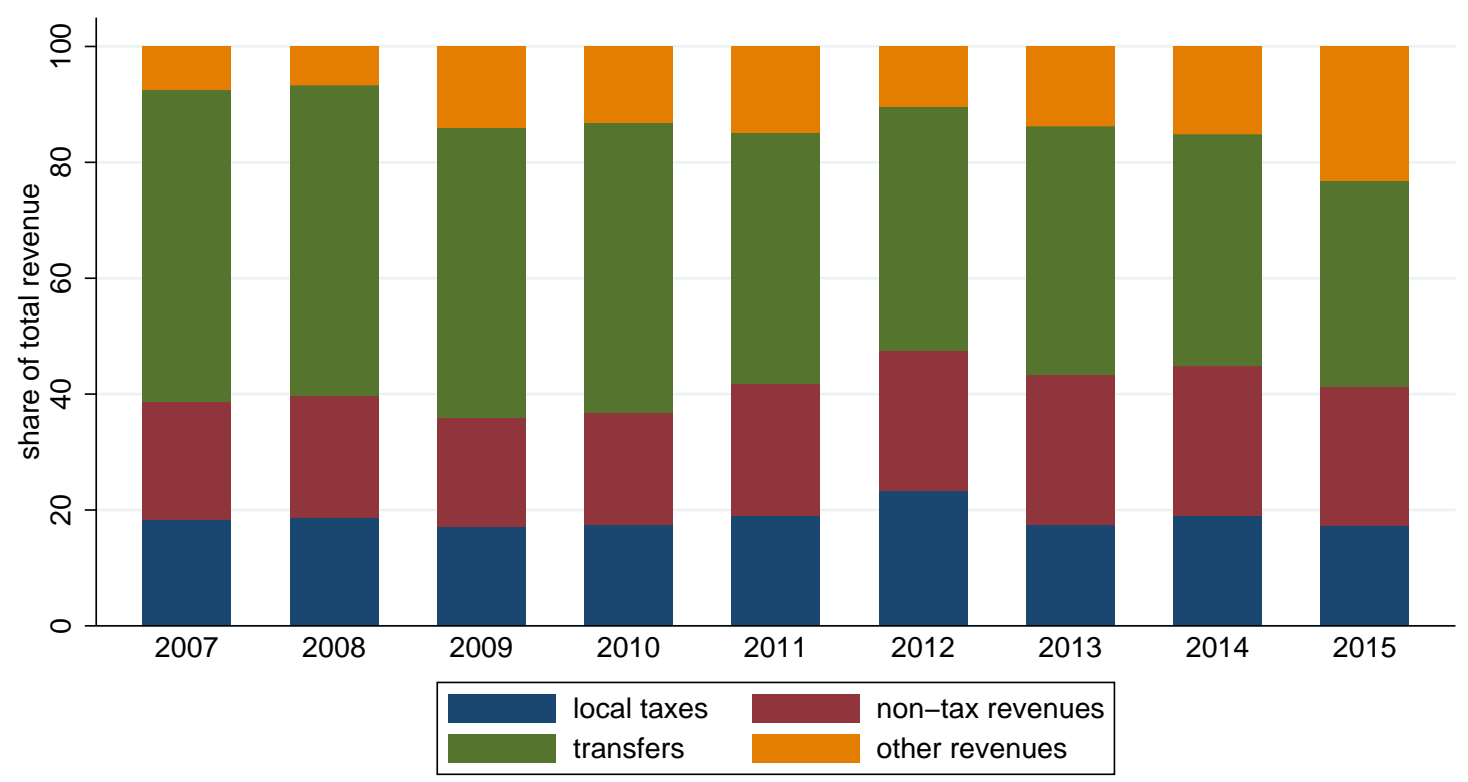

Notes: This figure plots the share of total revenue for different revenue categories of Italian municipalities below 2,500 inhabitants. Transfers also include revenues from the solidarity fund, financed by the property tax. Source: Municipal budget accounts (Conti consuntivi, accrual basis, Ministry of the Interior.) 
Figure B.2: Distribution of exemption levels

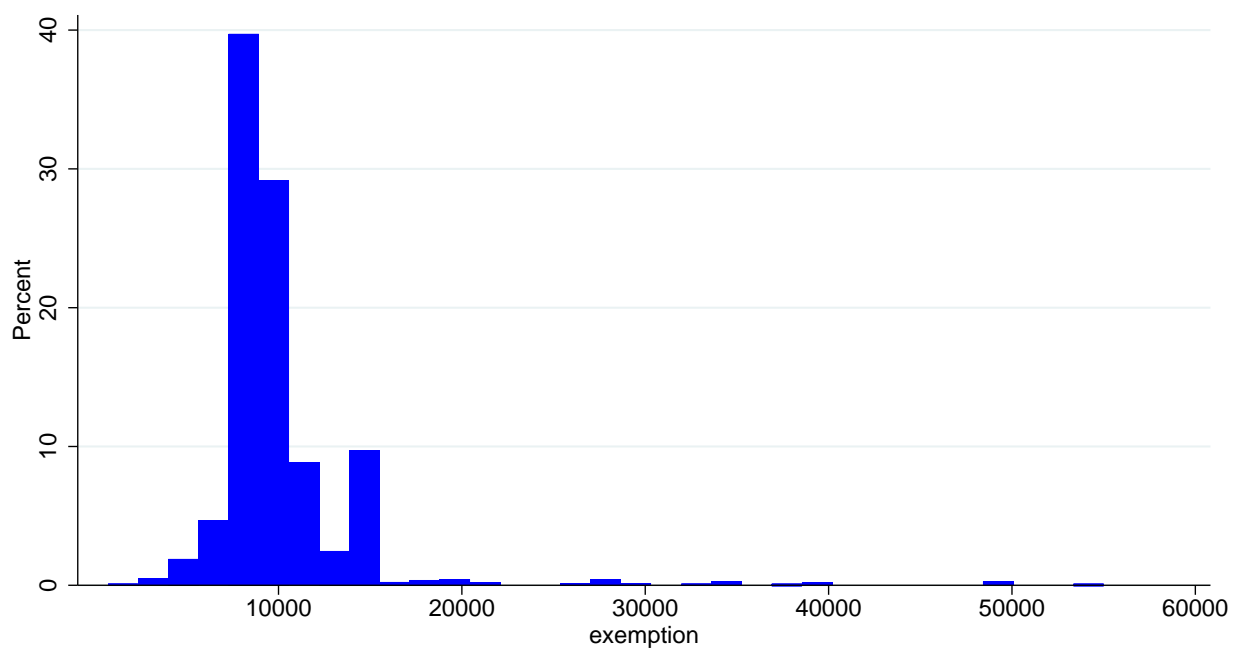

Notes: This figure plots the density of exemption levels for the local personal income tax in Italian municipalities. The sample is restricted to municipalities that have a positive exemption level and less than 2,500 inhabitants.

Figure B.3: Map of Italian municipalities

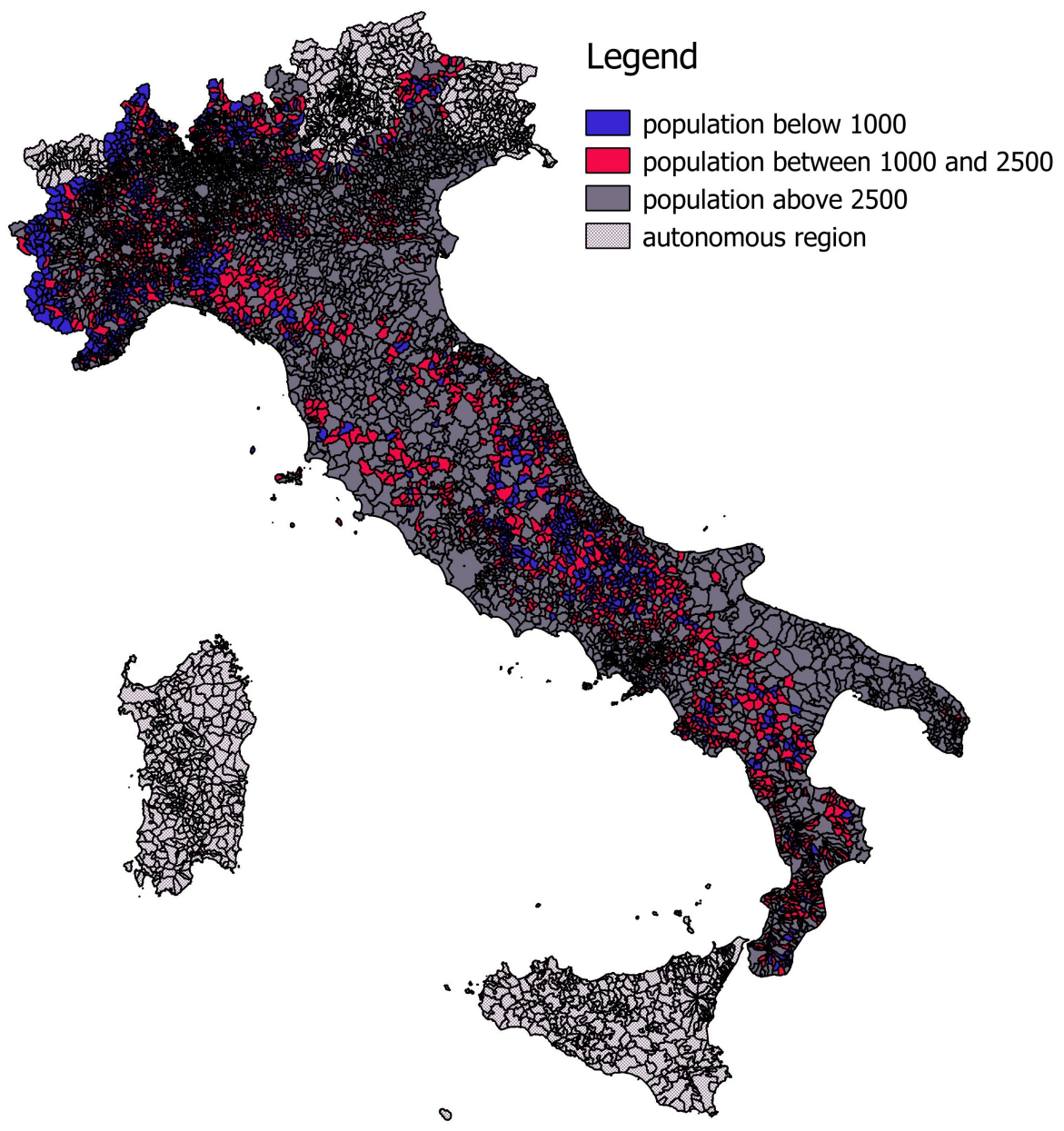

Notes: Municipalities in red or in blue are included in the sample. 
Figure B.4: Distribution of taxpayers

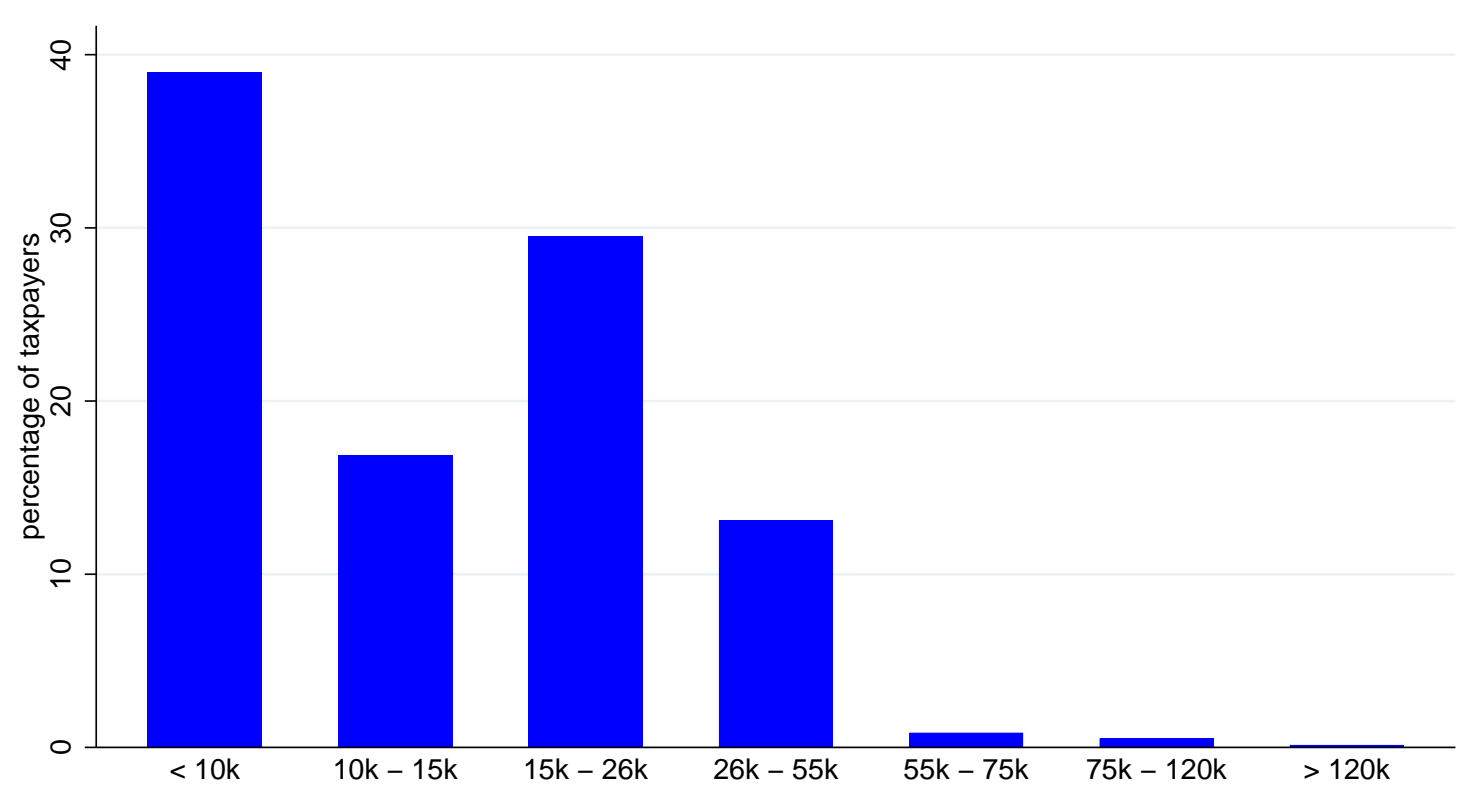

Notes: This figure plots the percentage of tax payers in each taxable income bracket for municipalities with less than 2,500 inhabitants. 
Table B.3: Descriptive statistics

\begin{tabular}{|c|c|c|c|c|c|c|c|c|c|c|}
\hline & \multicolumn{3}{|c|}{ full sample } & \multicolumn{3}{|c|}{ population $\leq 2500$} & \multicolumn{3}{|c|}{ population $>2500$} & \multirow{3}{*}{$\begin{array}{c}(10) \\
\text { difference }\end{array}$} \\
\hline & (1) & (2) & (3) & (4) & (5) & (6) & (7) & (8) & (9) & \\
\hline & mean & sd & $\mathrm{N}$ & mean & sd & $\mathrm{N}$ & mean & sd & $\mathrm{N}$ & \\
\hline area $\left(\right.$ in $\mathrm{km}^{2}$ ) & 34.384 & 47.298 & 58,323 & 23.364 & 23.063 & 28,335 & 44.795 & 60.209 & 29,988 & $-21.431^{* * *}$ \\
\hline coast dummy & 0.068 & 0.252 & 58,323 & 0.022 & 0.147 & 28,335 & 0.112 & 0.315 & 29,988 & $-0.090^{* * *}$ \\
\hline altitude (in m) & 334.405 & 275.099 & 58,323 & 448.871 & 292.956 & 28,335 & 226.249 & 204.985 & 29,988 & $222.622^{* * *}$ \\
\hline mayor: age & 51.912 & 10.138 & 57,278 & 52.018 & 10.550 & 28,068 & 51.811 & 9.725 & 29,210 & 0.207 \\
\hline mayor: female & 0.118 & 0.322 & 57,278 & 0.117 & 0.322 & 28,068 & 0.118 & 0.322 & 29,210 & -0.001 \\
\hline mayor: college degree & 0.454 & 0.498 & 56,581 & 0.364 & 0.481 & 27,642 & 0.540 & 0.498 & 28,939 & $-0.176^{* * *}$ \\
\hline mayor: high-skill occupation & 0.378 & 0.485 & 55,517 & 0.306 & 0.461 & 27,335 & 0.448 & 0.497 & 28,182 & $-0.142^{* * *}$ \\
\hline mayor: political & 0.295 & 0.456 & 56,481 & 0.154 & 0.361 & 27,646 & 0.430 & 0.495 & 28,835 & $-0.275^{* * *}$ \\
\hline mayor: last win margin & 0.259 & 0.256 & 57,346 & 0.318 & 0.306 & 28,098 & 0.201 & 0.179 & 29,248 & $0.117^{* * *}$ \\
\hline mayor: term limit & 0.302 & 0.459 & 57,181 & 0.287 & 0.452 & 28,007 & 0.317 & 0.465 & 29,174 & $-0.030^{* * *}$ \\
\hline years to next election & 1.994 & 1.410 & 57,095 & 1.980 & 1.404 & 27,911 & 2.008 & 1.415 & 29,184 & $-0.028^{* * *}$ \\
\hline share: age $\geq 60$ & 0.292 & 0.064 & 58,323 & 0.321 & 0.068 & 28,335 & 0.265 & 0.045 & 29,988 & $0.056^{* * *}$ \\
\hline share: female & 0.508 & 0.015 & 58,323 & 0.505 & 0.019 & 28,335 & 0.511 & 0.010 & 29,988 & $-0.005^{* * *}$ \\
\hline share: college degree & 0.074 & 0.027 & 58,323 & 0.067 & 0.024 & 28,335 & 0.081 & 0.028 & 29,988 & $-0.014^{* * *}$ \\
\hline top income share & 0.106 & 0.078 & 58,323 & 0.075 & 0.075 & 28,335 & 0.135 & 0.068 & 29,988 & $-0.060^{* * *}$ \\
\hline taxable income per capita & $12,605.327$ & $3,309.273$ & 57,569 & $11,962.550$ & $3,047.158$ & 28,148 & $13,220.292$ & $3,431.061$ & 29,421 & $-1,257.742^{* * *}$ \\
\hline tax rate at the 1 st decile & 0.348 & 0.279 & 58,062 & 0.329 & 0.264 & 28,148 & 0.366 & 0.292 & 29,914 & $-0.037^{* * *}$ \\
\hline tax rate at the 2 nd decile & 0.355 & 0.278 & 58,062 & 0.333 & 0.264 & 28,148 & 0.377 & 0.290 & 29,914 & $-0.044^{* * *}$ \\
\hline tax rate at the 3 rd decile & 0.388 & 0.272 & 58,062 & 0.346 & 0.262 & 28,148 & 0.426 & 0.276 & 29,914 & $-0.080^{* * *}$ \\
\hline tax rate at the 4 th decile & 0.412 & 0.265 & 58,062 & 0.358 & 0.259 & 28,148 & 0.464 & 0.260 & 29,914 & $-0.105^{* * *}$ \\
\hline tax rate at the 5 th decile & 0.425 & 0.259 & 58,062 & 0.365 & 0.257 & 28,148 & 0.482 & 0.248 & 29,914 & $-0.117^{* * *}$ \\
\hline tax rate at the 6 th decile & 0.430 & 0.256 & 58,062 & 0.367 & 0.256 & 28,148 & 0.490 & 0.241 & 29,914 & $-0.123^{* * *}$ \\
\hline tax rate at the 7 th decile & 0.433 & 0.255 & 58,062 & 0.369 & 0.255 & 28,148 & 0.494 & 0.239 & 29,914 & $-0.125^{* * *}$ \\
\hline tax rate at the 8 th decile & 0.436 & 0.254 & 58,062 & 0.370 & 0.255 & 28,148 & 0.498 & 0.236 & 29,914 & $-0.128^{* * *}$ \\
\hline tax rate at the 9 th decile & 0.440 & 0.253 & 58,062 & 0.372 & 0.255 & 28,148 & 0.504 & 0.234 & 29,914 & $-0.132^{* * *}$ \\
\hline average rate progression & 0.428 & 1.000 & 58,323 & 0.198 & 0.672 & 28,335 & 0.646 & 1.192 & 29,988 & $-0.448^{* * *}$ \\
\hline marginal rate progression & 0.433 & 1.000 & 58,323 & 0.204 & 0.690 & 28,335 & 0.649 & 1.183 & 29,988 & $-0.444^{* * *}$ \\
\hline exemption level & $2,019.226$ & $4,718.198$ & 58,035 & 997.086 & $3,348.429$ & 28,135 & $2,981.029$ & $5,545.364$ & 29,900 & $-1983.943^{* * *}$ \\
\hline progressive tax & 0.179 & 0.383 & 58,062 & 0.094 & 0.292 & 28,148 & 0.259 & 0.438 & 29,914 & $-0.166^{* * *}$ \\
\hline deficit & 0.136 & 202.621 & 57,400 & 5.711 & 268.320 & 28,061 & -5.197 & 106.800 & 29,339 & $10.908^{* * *}$ \\
\hline income tax revenues & 45.811 & 32.760 & 57,104 & 36.972 & 32.142 & 27,822 & 54.209 & 31.091 & 29,282 & $-17.237^{* * *}$ \\
\hline property tax revenues & 173.672 & 476.889 & 57,104 & 182.533 & 249.620 & 27,822 & 165.252 & 619.811 & 29,282 & $17.281^{* * *}$ \\
\hline trash tax revenues & 106.744 & 84.675 & 57,104 & 114.252 & 88.938 & 27,822 & 99.610 & 79.764 & 29,282 & $14.642^{* * *}$ \\
\hline non-tax revenues & 370.977 & 467.983 & 57,104 & 443.152 & 627.985 & 27,822 & 302.401 & 206.758 & 29,282 & $140.751^{* * *}$ \\
\hline transfer revenues & 682.851 & $1,296.016$ & 57,104 & 993.877 & $1,752.916$ & 27,822 & 387.333 & 420.556 & 29,282 & $606.544^{* * *}$ \\
\hline loan revenues & 143.526 & 383.864 & 57,104 & 173.298 & 489.218 & 27,822 & 115.238 & 241.489 & 29,282 & $58.060^{* * *}$ \\
\hline other revenues & 104.349 & 700.645 & 57,104 & 137.844 & 760.640 & 27,822 & 72.525 & 636.822 & 29,282 & $65.319^{* * *}$ \\
\hline total expenditures & $1,371.050$ & $1,676.247$ & 57,656 & $1,784.216$ & $2,254.043$ & 28,237 & 974.485 & 555.983 & 29,419 & $809.730^{* * *}$ \\
\hline current expenditures & 859.789 & 595.954 & 57,656 & $1,003.021$ & 772.813 & 28,237 & 722.312 & 290.224 & 29,419 & $280.709^{* * *}$ \\
\hline capital expenditures & 511.262 & $1,360.819$ & 57,656 & 781.195 & $1,858.662$ & 28,237 & 252.174 & 420.030 & 29,419 & $529.022^{* * *}$ \\
\hline exp: administrative & 358.101 & 415.556 & 57,656 & 471.887 & 530.687 & 28,237 & 248.887 & 209.219 & 29,419 & $223.000^{* * *}$ \\
\hline exp: culture & 25.129 & 98.424 & 57,656 & 27.745 & 133.727 & 28,237 & 22.619 & 42.526 & 29,419 & $5.126^{* * *}$ \\
\hline exp: development & 15.072 & 123.668 & 57,656 & 19.856 & 167.832 & 28,237 & 10.481 & 53.803 & 29,419 & $9.374^{* * *}$ \\
\hline exp: education & 97.632 & 123.998 & 57,656 & 102.513 & 155.077 & 28,237 & 92.947 & 83.705 & 29,419 & $9.566^{* * *}$ \\
\hline exp: environment & 320.293 & 949.229 & 57,656 & 445.122 & $1,323.818$ & 28,237 & 200.479 & 233.465 & 29,419 & $244.643^{* * *}$ \\
\hline exp: judiciary & 1.132 & 12.033 & 57,656 & 0.591 & 14.434 & 28,237 & 1.651 & 9.124 & 29,419 & $-1.060^{* * *}$ \\
\hline exp: police & 32.768 & 44.306 & 57,656 & 33.043 & 57.428 & 28,237 & 32.505 & 26.107 & 29,419 & 0.537 \\
\hline exp: social & 97.483 & 152.768 & 57,656 & 93.587 & 183.620 & 28,237 & 101.223 & 115.537 & 29,419 & $-7.635^{* * *}$ \\
\hline exp: sport & 32.031 & 341.246 & 57,656 & 43.866 & 485.028 & 28,237 & 20.671 & 46.479 & 29,419 & $23.195^{* * *}$ \\
\hline exp: resources & 25.341 & 461.792 & 57,656 & 39.354 & 649.422 & 28,237 & 11.890 & 113.004 & 29,419 & $27.464^{* * *}$ \\
\hline exp: transport & 183.282 & 376.503 & 57,656 & 264.642 & 511.934 & 28,237 & 105.191 & 117.561 & 29,419 & $159.451^{* * *}$ \\
\hline exp: tourism & 26.458 & 278.320 & 57,656 & 43.964 & 390.665 & 28,237 & 9.655 & 68.931 & 29,419 & $34.309^{* * *}$ \\
\hline re-run & 0.594 & 0.491 & 13,149 & 0.599 & 0.490 & 6,563 & 0.400 & 0.492 & 6,586 & 0.010 \\
\hline reelection & 0.798 & 0.401 & 8,271 & 0.827 & 0.378 & 4,266 & 0.768 & 0.422 & 4,005 & $0.059^{* * *}$ \\
\hline
\end{tabular}

Notes: ${ }^{*} p<0.1,{ }^{* *} p<0.05,{ }^{* * *} p<0.01$; Column 10 displays the difference between columns 4 and 7 . All expenditure, revenue, and deficit variables are expressed in per capita terms and 2015 Euros. 
Table B.4: Descriptive statistics: matched sample

\begin{tabular}{|c|c|c|c|c|c|c|c|}
\hline & \multicolumn{3}{|c|}{ matched sample } & \multicolumn{3}{|c|}{ non-matched sample } & \multirow{3}{*}{$\begin{array}{c}(7) \\
\text { difference }\end{array}$} \\
\hline & (1) & $(2)$ & (3) & (4) & $(5)$ & (6) & \\
\hline & mean & sd & $\mathrm{N}$ & mean & sd & $\mathrm{N}$ & \\
\hline area $\left(\right.$ in $\mathrm{km}^{2}$ ) & 34.855 & 47.672 & 44,781 & 33.000 & 45.448 & 12,357 & $1.855^{* *}$ \\
\hline coast dummy & 0.067 & 0.250 & 44,781 & 0.071 & 0.257 & 12,357 & -0.004 \\
\hline altitude (in m) & 332.851 & 275.745 & 44,781 & 342.933 & 277.283 & 12,357 & $-10.082^{*}$ \\
\hline mayor: female & 0.115 & 0.319 & 44,768 & 0.127 & 0.333 & 12,249 & $-0.012^{*}$ \\
\hline mayor: college degree & 0.456 & 0.498 & 44,240 & 0.451 & 0.498 & 12,082 & 0.004 \\
\hline mayor: age & 51.807 & 10.072 & 44,768 & 52.261 & 10.312 & 12,249 & $-0.454^{* *}$ \\
\hline mayor: political & 0.296 & 0.457 & 44,129 & 0.293 & 0.455 & 12,093 & 0.003 \\
\hline mayor: term limit & 0.295 & 0.456 & 44,725 & 0.330 & 0.470 & 12,196 & $-0.036^{* * *}$ \\
\hline years to next election & 2.007 & 1.433 & 44,779 & 1.949 & 1.319 & 12,316 & $0.058^{* * *}$ \\
\hline share: college degree & 0.074 & 0.027 & 44,781 & 0.074 & 0.028 & 12,357 & 0.000 \\
\hline share: female & 0.508 & 0.015 & 44,781 & 0.507 & 0.016 & 12,357 & $0.001^{* *}$ \\
\hline share: age $\geq 60$ & 0.292 & 0.064 & 44,781 & 0.296 & 0.064 & 12,357 & $-0.004^{* * *}$ \\
\hline top income share & 0.105 & 0.077 & 44,781 & 0.104 & 0.079 & 12,357 & 0.001 \\
\hline taxable income per capita & $12,557.276$ & $3,307.428$ & 44,549 & $12,696.957$ & $3,273.648$ & 12,272 & $-139.681^{* *}$ \\
\hline average rate progression & 0.427 & 0.999 & 44,781 & 0.398 & 0.966 & 12,357 & $0.029^{*}$ \\
\hline marginal rate progression & 0.431 & 0.998 & 44,781 & 0.403 & 0.966 & 12,357 & $0.028^{*}$ \\
\hline exemption level & $2,006.282$ & $4,701.750$ & 44,764 & $1,930.638$ & $4,669.887$ & 12,353 & 75.644 \\
\hline progressive tax & 0.178 & 0.383 & 44,781 & 0.170 & 0.375 & 12,357 & 0.009 \\
\hline runner-up: female & 0.147 & 0.354 & 44,781 & & & & \\
\hline runner-up: age & 51.830 & 10.951 & 44,781 & & & & \\
\hline runner-up: college degree & 0.443 & 0.497 & 43,232 & & & & \\
\hline runner-up: political & 0.277 & 0.447 & 41,809 & & & & \\
\hline vote margin & -0.033 & 0.291 & 44,240 & & & & \\
\hline mixed race & 0.439 & 0.496 & 42,765 & & & & \\
\hline
\end{tabular}

Notes: The matched sample includes observations for which we were able to match the main dataset with the election data. The non-matched sample includes the remaining observations. ${ }^{*} p<0.1,{ }^{* *} p<0.05$, ${ }^{* * *} p<0.01$; Column 7 displays the difference between columns 1 and 4 . 


\section{Additional Findings}

Figure C.1: Regression discontinuity plots: other outcomes

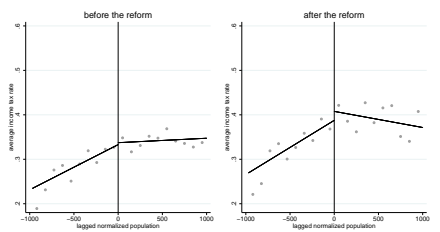

(a) 2nd decile

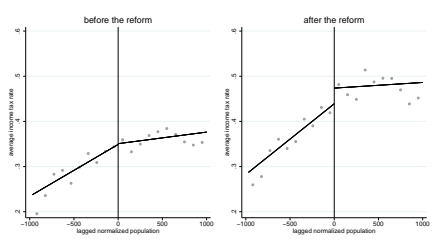

(d) 5 th decile
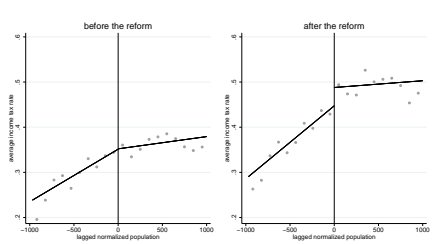

(g) 8th decile

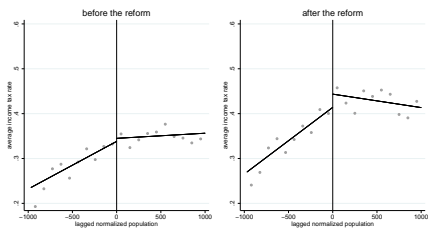

(b) 3rd decile

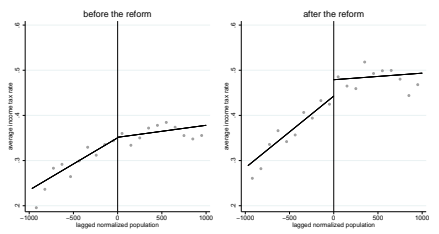

(e) 6th decile
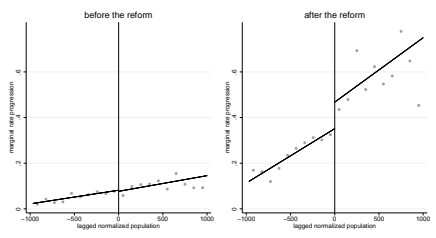

(h) marginal rate progression

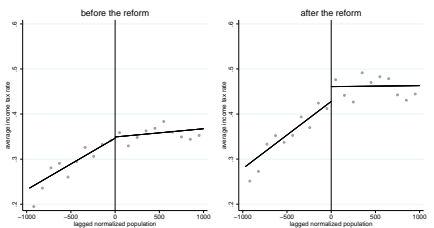

(c) 4th decile

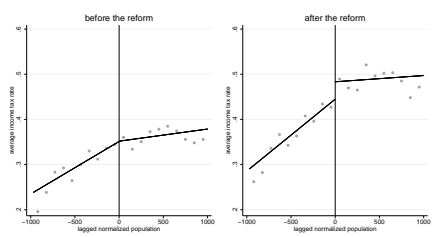

(f) 7th decile

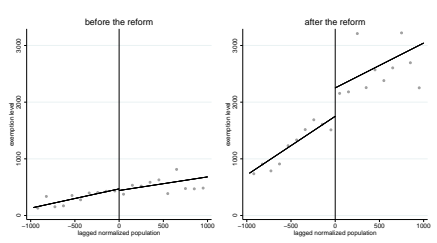

(i) exemption level

Notes: The reform is the introduction of the fiscal rule for municipalities above 1,000 inhabitants in 2013. Each graph is a regression discontinuity plot for pre-reform years (2007-12, on the left) and post-reform years (2013-15, on the right). The outcome variable is reported underneath each graph. The running variable is lagged normalized population. Plots are obtained with the STATA command rdplot (Calonico et al., 2015) organizing the data in 10 bins on each side of the threshold. The lines are linear fits estimated separately on each side of the threshold.

Table C.1: Effect of the reform on the average income tax rate at different income levels

\begin{tabular}{|c|c|c|c|c|c|c|c|c|c|c|c|c|c|c|c|}
\hline & (1) & (2) & (3) & (4) & $(5)$ & (6) & (7) & (8) & (9) & (10) & (11) & (12) & (13) & (14) & (15) \\
\hline & $5 \mathrm{k} €$ & $10 \mathrm{k} €$ & $15 \mathrm{k} €$ & $20 \mathrm{k} €$ & $25 \mathrm{k} €$ & $30 \mathrm{k} €$ & $35 \mathrm{k} €$ & $40 \mathrm{k} €$ & $45 \mathrm{k} €$ & $50 \mathrm{k} €$ & $55 \mathrm{k} €$ & $60 \mathrm{k} €$ & $65 \mathrm{k} €$ & $70 \mathrm{k} €$ & $75 \mathrm{k} €$ \\
\hline \multirow[t]{2}{*}{ LATE } & 0.014 & 0.032 & $0.034^{*}$ & $0.038^{* *}$ & $0.040^{* *}$ & $0.040^{* *}$ & $0.042^{* *}$ & $0.043^{* *}$ & $0.044^{* *}$ & $0.044^{* *}$ & ${ }^{*} 0.044^{* *}$ & $0.045^{* *}$ & $0.045^{* *}$ & $0.045^{* *}$ & $0.046^{* *}$ \\
\hline & $(0.020)$ & $(0.019)$ & $(0.018)$ & $(0.018)$ & $(0.018)$ & $(0.018)$ & $(0.018)$ & $(0.018)$ & $(0.018)$ & $(0.018)$ & $(0.018)$ & $(0.018)$ & $(0.018)$ & $(0.018)$ & $(0.018)$ \\
\hline$>5 \mathrm{k} €$ & - & 0.034 & 0.049 & 0.026 & 0.020 & 0.020 & 0.015 & 0.013 & 0.013 & 0.012 & 0.012 & 0.012 & 0.012 & 0.012 & 0.012 \\
\hline$>10 \mathrm{k} €$ & - & - & 0.358 & 0.195 & 0.152 & 0.152 & 0.116 & 0.106 & 0.100 & 0.096 & 0.093 & 0.091 & 0.089 & 0.088 & 0.087 \\
\hline$>15 \mathrm{k} €$ & - & - & - & 0.109 & 0.067 & 0.076 & 0.050 & 0.046 & 0.044 & 0.043 & 0.043 & 0.044 & 0.044 & 0.045 & 0.046 \\
\hline mean & 0.331 & 0.351 & 0.363 & 0.367 & 0.368 & 0.368 & 0.369 & 0.370 & 0.371 & 0.371 & 0.371 & 0.372 & 0.372 & 0.372 & 0.373 \\
\hline bandwidth & 663 & 663 & 663 & 663 & 663 & 663 & 663 & 663 & 663 & 663 & 663 & 663 & 663 & 663 & 663 \\
\hline $\mathrm{N}$ & 17,660 & 17,660 & 17,660 & 17,660 & 17,660 & 17,660 & 17,660 & 17,660 & 17,660 & 17,660 & 17,660 & 17,660 & 17,660 & 17,660 & 17,660 \\
\hline
\end{tabular}

Notes: The reform is the introduction of the fiscal rule for municipalities above 1,000 inhabitants in 2013. The top panel reports the local average treatment effect (LATE) of the difference-in-discontinuities model estimated with a separate local linear regression for each outcome variable (reported at the top of each column). The LATE corresponds to $\beta_{6}$ in equation 2. The bandwidth is selected following Grembi et al. (2016). The middle panel displays p-values for pairwise one-sided tests (estimated by seemingly unrelated regression) whether the effect is higher than the effect on the tax rate at yearly incomes of $5,000 €, 10,000 €$, and $15,000 €$ respectively. In the bottom panel, the sample mean of the outcome variable, the used bandwidth and the number of observations are shown. Statistical significance denoted as: ${ }^{*} p<0.1,{ }^{* *} p<0.05,{ }^{* * *} p<0.01$ 
Figure C.2: Effect of the reform on income tax rates at different income levels

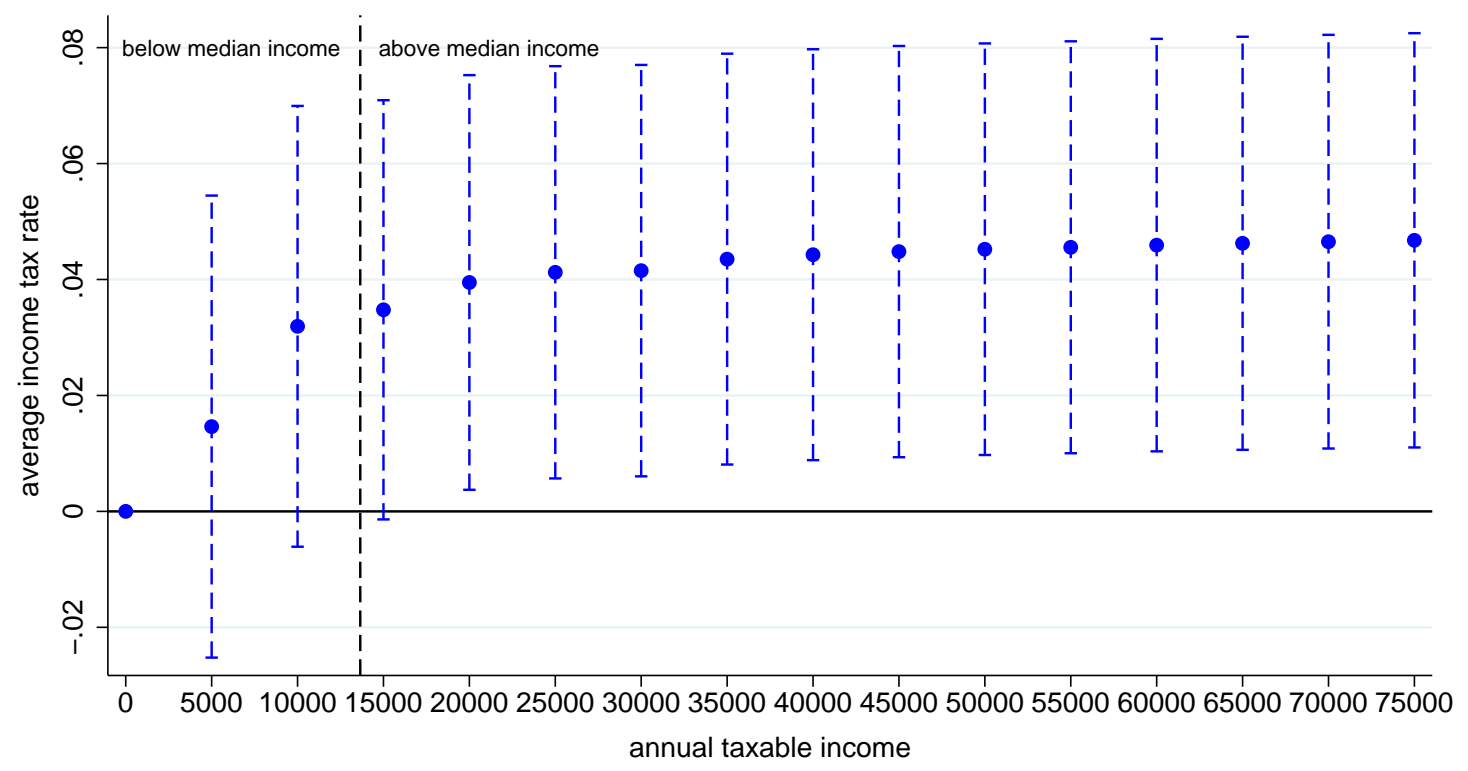

Notes: This figure plots the local average treatment effects reported in Table C.1 and their 95\% confidence bands 
Table C.2: Differential effect of the reform by mayor's skill

\begin{tabular}{|c|c|c|c|c|c|c|c|c|}
\hline & $\begin{array}{c}(1) \\
\text { progressive } \\
\operatorname{tax}\end{array}$ & $\begin{array}{c}(2) \\
\text { progressive } \\
\text { tax }\end{array}$ & $\begin{array}{c}(3) \\
\text { progressive } \\
\text { tax }\end{array}$ & $\begin{array}{c}(4) \\
\text { progressive } \\
\text { tax }\end{array}$ & $\begin{array}{c}(5) \\
\text { progressive } \\
\text { tax }\end{array}$ & $\begin{array}{c}(6) \\
\text { progressive } \\
\operatorname{tax}\end{array}$ & $\begin{array}{c}(7) \\
\text { progressive } \\
\text { tax }\end{array}$ & $\begin{array}{c}(8) \\
\text { progressive } \\
\operatorname{tax}\end{array}$ \\
\hline LATE & $\begin{array}{l}-0.002 \\
(0.034)\end{array}$ & $\begin{array}{l}-0.002 \\
(0.034)\end{array}$ & $\begin{array}{l}-0.020 \\
(0.032)\end{array}$ & $\begin{array}{l}-0.008 \\
(0.070)\end{array}$ & $\begin{array}{l}-0.000 \\
(0.032)\end{array}$ & $\begin{array}{c}0.004 \\
(0.032)\end{array}$ & $\begin{array}{l}-0.009 \\
(0.031)\end{array}$ & $\begin{array}{c}0.012 \\
(0.069)\end{array}$ \\
\hline LATE $x$ college degree & $\begin{array}{l}0.138^{* * *} \\
(0.053)\end{array}$ & $\begin{array}{l}0.136^{* * * *} \\
(0.052)\end{array}$ & $\begin{array}{l}0.121^{* * *} \\
(0.046)\end{array}$ & $\begin{array}{l}0.116^{* *} \\
(0.046)\end{array}$ & & & & \\
\hline LATE $x$ high-skill job & & & & & $\begin{array}{l}0.153^{* * *} \\
(0.059)\end{array}$ & $\begin{array}{l}0.141^{* *} \\
(0.059)\end{array}$ & $\begin{array}{l}0.113^{* *} \\
(0.051)\end{array}$ & $\begin{array}{l}0.106^{* *} \\
(0.050)\end{array}$ \\
\hline LATE $\mathrm{x}$ female mayor & & & & $\begin{array}{l}0.045 \\
(0.070)\end{array}$ & & & & $\begin{array}{l}0.045 \\
(0.072)\end{array}$ \\
\hline LATE $\mathrm{x}$ left-wing mayor & & & & $\begin{array}{c}0.006 \\
(0.064)\end{array}$ & & & & $\begin{array}{c}0.006 \\
(0.065)\end{array}$ \\
\hline LATE $\mathrm{x}$ right-wing mayor & & & & $\begin{array}{l}-0.190 \\
(0.134)\end{array}$ & & & & $\begin{array}{l}-0.187 \\
(0.136)\end{array}$ \\
\hline LATE $\mathrm{x}$ centrist mayor & & & & $\begin{array}{l}-0.292 \\
(0.232)\end{array}$ & & & & $\begin{array}{l}-0.327 \\
(0.253)\end{array}$ \\
\hline LATE $\mathrm{x}$ low win margin & & & & $\begin{array}{l}0.027 \\
(0.047)\end{array}$ & & & & $\begin{array}{c}0.024 \\
(0.048)\end{array}$ \\
\hline LATE $x$ term limit & & & & $\begin{array}{l}-0.007 \\
(0.041)\end{array}$ & & & & $\begin{array}{l}-0.021 \\
(0.042)\end{array}$ \\
\hline LATE $\mathrm{x}$ high pre-reform deficit & & & & $\begin{array}{c}0.037 \\
(0.054)\end{array}$ & & & & $\begin{array}{l}0.029 \\
(0.054)\end{array}$ \\
\hline LATE $\mathrm{x}$ low top income share & & & & $\begin{array}{l}-0.076 \\
(0.054)\end{array}$ & & & & $\begin{array}{l}-0.077 \\
(0.055)\end{array}$ \\
\hline $\begin{array}{l}\text { controls } \\
\text { municipality FE }\end{array}$ & & yes & $\begin{array}{l}\text { yes } \\
\text { yes }\end{array}$ & $\begin{array}{l}\text { yes } \\
\text { yes }\end{array}$ & & yes & $\begin{array}{l}\text { yes } \\
\text { yes }\end{array}$ & $\begin{array}{l}\text { yes } \\
\text { yes }\end{array}$ \\
\hline mean & 0.087 & 0.088 & 0.088 & 0.088 & 0.086 & 0.088 & 0.088 & 0.088 \\
\hline bandwidth & 650 & 650 & 650 & 650 & 650 & 650 & 650 & 650 \\
\hline $\mathrm{N}$ & 16,932 & 16,663 & 16,663 & 16,663 & 16,848 & 16,321 & 16,321 & 16,321 \\
\hline
\end{tabular}

Notes: The reform is the introduction of the fiscal rule for municipalities above 1,000 inhabitants in 2013. The table reports estimates of difference-in-discontinuities models extended to estimate heterogeneous treatment effects. The extended models include one or more binary covariates and their interactions with all the terms included in the baseline model. The row LATE reports the local average treatment effect in case the additional interaction variables are equal to zero $\left(\beta_{6}\right)$, while the interaction rows report the differential effects when the interaction variables are switched on $\left(\beta_{6}^{i n t}\right)$ in equation 3. We measure mayors' skills using two dummies: college degree, which is equal to one in case the mayor holds one; and high-skill job, which is equal to one in case the mayor was employed in a managing position or in an intellectual profession (e.g. lawyer, medical doctor). Details on all covariates are described in Section 4. The estimation method is local linear regression. The bandwidth is selected following Grembi et al. (2016). In the bottom panel, the sample mean of the outcome variable, the used bandwidth and the number of observations are shown. Statistical significance denoted as: ${ }^{*} p<0.1,{ }^{* *} p<0.05,{ }^{* * *} p<0.01$ 
Table C.3: Differential effect of the reform by mayor's skill

\begin{tabular}{|c|c|c|c|c|c|c|c|c|}
\hline & $\begin{array}{c}(1) \\
\text { exemption } \\
\text { level }\end{array}$ & $\begin{array}{c}(2) \\
\text { exemption } \\
\text { level }\end{array}$ & $\begin{array}{c}(3) \\
\text { exemption } \\
\text { level }\end{array}$ & $\begin{array}{c}(4) \\
\text { exemption } \\
\text { level }\end{array}$ & $\begin{array}{c}(5) \\
\text { exemption } \\
\text { level }\end{array}$ & $\begin{array}{c}\text { (6) } \\
\text { exemption } \\
\text { level }\end{array}$ & $\begin{array}{c}(7) \\
\text { exemption } \\
\text { level }\end{array}$ & $\begin{array}{c}(8) \\
\text { exemption } \\
\text { level }\end{array}$ \\
\hline LATE & $\begin{array}{c}-45 \\
(406)\end{array}$ & $\begin{array}{r}2 \\
(403)\end{array}$ & $\begin{array}{l}-211 \\
(385)\end{array}$ & $\begin{array}{c}167 \\
(861)\end{array}$ & $\begin{array}{c}-77 \\
(357)\end{array}$ & $\begin{array}{c}10 \\
(354)\end{array}$ & $\begin{array}{l}-158 \\
(355)\end{array}$ & $\begin{array}{c}289 \\
(830)\end{array}$ \\
\hline LATE $\mathrm{x}$ college degree & $\begin{array}{l}1494^{* *} \\
(604)\end{array}$ & $\begin{array}{l}1457^{* *} \\
(603)\end{array}$ & $\begin{array}{l}1363^{* *} \\
(553)\end{array}$ & $\begin{array}{l}1361^{* *} \\
(558)\end{array}$ & & & & \\
\hline LATE $x$ high-skill job & & & & & $\begin{array}{l}1918^{* * *} \\
(700)\end{array}$ & $\begin{array}{l}1741^{* *} \\
(705)\end{array}$ & $\begin{array}{l}1629^{* *} \\
(656)\end{array}$ & $\begin{array}{l}1552^{* *} \\
(647)\end{array}$ \\
\hline LATE $\mathrm{x}$ female mayor & & & & $\begin{array}{c}466 \\
(819)\end{array}$ & & & & $\begin{array}{c}339 \\
(847)\end{array}$ \\
\hline LATE $\mathrm{x}$ left-wing mayor & & & & $\begin{array}{c}-94 \\
(743)\end{array}$ & & & & $\begin{array}{c}-91 \\
(750)\end{array}$ \\
\hline LATE $\mathrm{x}$ right-wing mayor & & & & $\begin{array}{l}-1988 \\
(1612)\end{array}$ & & & & $\begin{array}{l}-1950 \\
(1646)\end{array}$ \\
\hline LATE $\mathrm{x}$ centrist mayor & & & & $\begin{array}{l}-4601 \\
(3388)\end{array}$ & & & & $\begin{array}{l}-4856 \\
(3518)\end{array}$ \\
\hline LATE $x$ low win margin & & & & $\begin{array}{c}124 \\
(571)\end{array}$ & & & & $\begin{array}{c}138 \\
(583)\end{array}$ \\
\hline LATE $x$ term limit & & & & $\begin{array}{l}-168 \\
(471)\end{array}$ & & & & $\begin{array}{l}-260 \\
(476)\end{array}$ \\
\hline LATE $\mathrm{x}$ high pre-reform deficit & & & & $\begin{array}{c}470 \\
(657)\end{array}$ & & & & $\begin{array}{c}366 \\
(656)\end{array}$ \\
\hline LATE $x$ low top income share & & & & $\begin{array}{r}-1115^{*} \\
(668)\end{array}$ & & & & $\begin{array}{r}-1068 \\
(670)\end{array}$ \\
\hline $\begin{array}{l}\text { controls } \\
\text { municipality FE }\end{array}$ & & yes & $\begin{array}{l}\text { yes } \\
\text { yes }\end{array}$ & $\begin{array}{l}\text { yes } \\
\text { yes }\end{array}$ & & yes & $\begin{array}{l}\text { yes } \\
\text { yes }\end{array}$ & $\begin{array}{l}\text { yes } \\
\text { yes }\end{array}$ \\
\hline mean & 896 & 906 & 906 & 906 & 886 & 904 & 904 & 904 \\
\hline bandwidth & 635 & 635 & 635 & 635 & 635 & 635 & 635 & 635 \\
\hline $\mathrm{N}$ & 16,577 & 16,319 & 16,319 & 16,319 & 16,493 & 15,985 & 15,985 & 15,985 \\
\hline
\end{tabular}

Notes: The reform is the introduction of the fiscal rule for municipalities above 1,000 inhabitants in 2013. The table reports estimates of difference-in-discontinuities models extended to estimate heterogeneous treatment effects. The extended models include one or more binary covariates and their interactions with all the terms included in the baseline model. The row LATE reports the local average treatment effect in case the additional interaction variables are equal to zero $\left(\beta_{6}\right)$, while the interaction rows report the differential effects when the interaction variables are switched on $\left(\beta_{6}^{i n t}\right)$ in equation 3. We measure mayors' skills using two dummies: college degree, which is equal to one in case the mayor holds one; and high-skill job, which is equal to one in case the mayor was employed in a managing position or in an intellectual profession (e.g. lawyer, medical doctor). Details on all covariates are described in Section 4. The estimation method is local linear regression. The bandwidth is selected following Grembi et al. (2016). In the bottom panel, the sample mean of the outcome variable, the used bandwidth and the number of observations are shown. Statistical significance denoted as: ${ }^{*} p<0.1,{ }^{* *} p<0.05,{ }^{* * *} p<0.01$ 
Table C.4: Differential effect of the reform by mayor's skill

\begin{tabular}{|c|c|c|c|c|c|c|c|c|}
\hline & $(1)$ & $(2)$ & $(3)$ & (4) & $(5)$ & (6) & $(7)$ & $(8)$ \\
\hline & $\begin{array}{c}\text { marginal rate } \\
\text { progression }\end{array}$ & $\begin{array}{c}\text { marginal rate } \\
\text { progression }\end{array}$ & $\begin{array}{c}\text { marginal rate } \\
\text { progression }\end{array}$ & $\begin{array}{c}\text { marginal rate } \\
\text { progression }\end{array}$ & $\begin{array}{c}\text { marginal rate } \\
\text { progression }\end{array}$ & $\begin{array}{c}\text { marginal rate } \\
\text { progression }\end{array}$ & $\begin{array}{c}\text { marginal rate } \\
\text { progression }\end{array}$ & $\begin{array}{c}\text { marginal rate } \\
\text { progression }\end{array}$ \\
\hline \multirow[t]{2}{*}{ LATE } & 0.005 & 0.006 & -0.009 & 0.055 & 0.016 & 0.024 & -0.002 & 0.080 \\
\hline & $(0.086)$ & $(0.086)$ & $(0.084)$ & $(0.180)$ & $(0.081)$ & $(0.082)$ & $(0.082)$ & $(0.176)$ \\
\hline \multirow[t]{2}{*}{ LATE $x$ college degree } & $0.353^{* * *}$ & $0.346^{* * *}$ & $0.281^{* *}$ & $0.281^{* *}$ & & & & \\
\hline & $(0.127)$ & $(0.126)$ & $(0.115)$ & $(0.117)$ & & & & \\
\hline \multirow[t]{2}{*}{ LATE $x$ high-skill job } & & & & & $0.393^{* * *}$ & $0.364^{* * *}$ & $0.329^{* * *}$ & $0.317^{* *}$ \\
\hline & & & & & $(0.139)$ & $(0.139)$ & $(0.127)$ & $(0.125)$ \\
\hline \multirow[t]{2}{*}{ LATE $\mathrm{x}$ female mayor } & & & & 0.039 & & & & 0.039 \\
\hline & & & & $(0.168)$ & & & & $(0.172)$ \\
\hline \multirow[t]{2}{*}{ LATE $\mathrm{x}$ left-wing mayor } & & & & -0.009 & & & & -0.008 \\
\hline & & & & $(0.160)$ & & & & $(0.161)$ \\
\hline \multirow[t]{2}{*}{ LATE $\mathrm{x}$ right-wing mayor } & & & & -0.459 & & & & -0.444 \\
\hline & & & & $(0.330)$ & & & & $(0.334)$ \\
\hline \multirow[t]{2}{*}{ LATE $\mathrm{x}$ centrist mayor } & & & & -0.523 & & & & $-0.630^{*}$ \\
\hline & & & & $(0.331)$ & & & & $(0.375)$ \\
\hline \multirow[t]{2}{*}{ LATE $x$ low win margin } & & & & 0.082 & & & & 0.076 \\
\hline & & & & $(0.121)$ & & & & $(0.125)$ \\
\hline \multirow[t]{2}{*}{ LATE $x$ term limit } & & & & -0.079 & & & & -0.105 \\
\hline & & & & $(0.105)$ & & & & $(0.107)$ \\
\hline \multirow[t]{2}{*}{ LATE $x$ high pre-reform deficit } & & & & 0.126 & & & & 0.115 \\
\hline & & & & $(0.140)$ & & & & $(0.140)$ \\
\hline \multirow[t]{2}{*}{ LATE $\mathrm{x}$ low top income share } & & & & $-0.244^{*}$ & & & & $-0.245^{*}$ \\
\hline & & & & $(0.143)$ & & & & $(0.144)$ \\
\hline controls & & yes & yes & yes & & yes & yes & yes \\
\hline municipality FE & & & yes & yes & & & yes & yes \\
\hline mean & 0.182 & 0.184 & 0.184 & 0.184 & 0.179 & 0.183 & 0.183 & 0.183 \\
\hline bandwidth & 668 & 668 & 668 & 668 & 668 & 668 & 668 & 668 \\
\hline $\mathrm{N}$ & 17,378 & 17,092 & 17,092 & 17,092 & 17,292 & 16,741 & 16,741 & 16,741 \\
\hline
\end{tabular}

Notes: The reform is the introduction of the fiscal rule for municipalities above 1,000 inhabitants in 2013. The table reports estimates of difference-in-discontinuities models extended to estimate heterogeneous treatment effects. The extended models include one or more binary covariates and their interactions with all the terms included in the baseline model. The row LATE reports the local average treatment effect in case the additional interaction variables are equal to zero $\left(\beta_{6}\right)$, while the interaction rows report the differential effects when the interaction variables are switched on $\left(\beta_{6}^{i n t}\right)$ in equation 3. We measure mayors' skills using two dummies: college degree, which is equal to one in case the mayor holds one; and high-skill job, which is equal to one in case the mayor was employed in a managing position or in an intellectual profession (e.g. lawyer, medical doctor). Details on all covariates are described in Section 4. The estimation method is local linear regression. The bandwidth is selected following Grembi et al. (2016). In the bottom panel, the sample mean of the outcome variable, the used bandwidth and the number of observations are shown. Statistical significance denoted as: ${ }^{*} p<0.1,{ }^{* *} p<0.05,{ }^{* * *} p<0.01$ 
Figure C.3: Effect of the reform on income tax rates by mayor's skill level

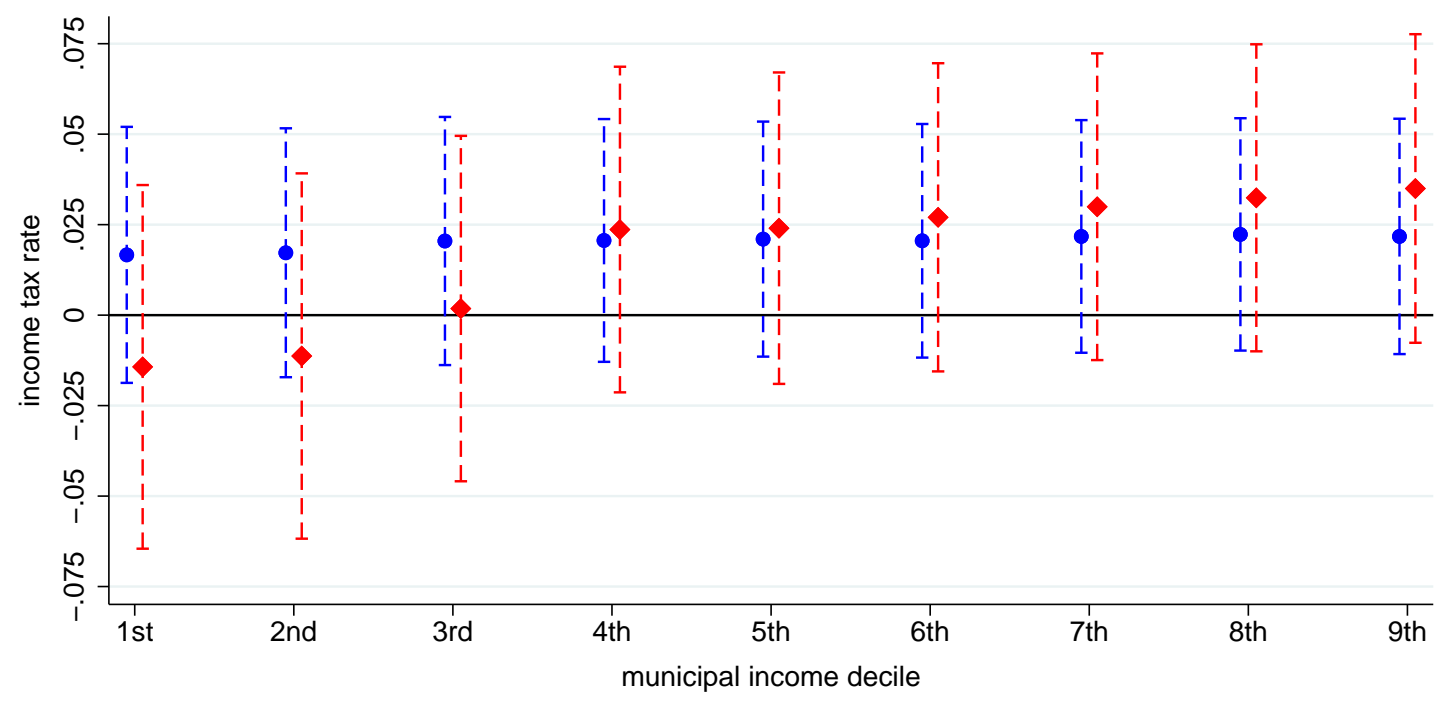

- mayor without college degree $>$ mayor with college degree

Notes: The reform is the introduction of the fiscal rule for municipalities above 1,000 inhabitants in 2013. The table reports estimates of difference-in-discontinuities models extended to estimate heterogeneous treatment effects. The blue estimates refer to the local average treatment effect for mayors without a college degree $\left(\beta_{6}\right)$, while the red estimates plot the sum of $\beta_{6}$ and $\beta_{6}^{\text {int }}$ referring to the effect for mayors with a college degree in equation 3. 
Table C.5: Differential effect of the reform by mayor's skill: mixed election RD

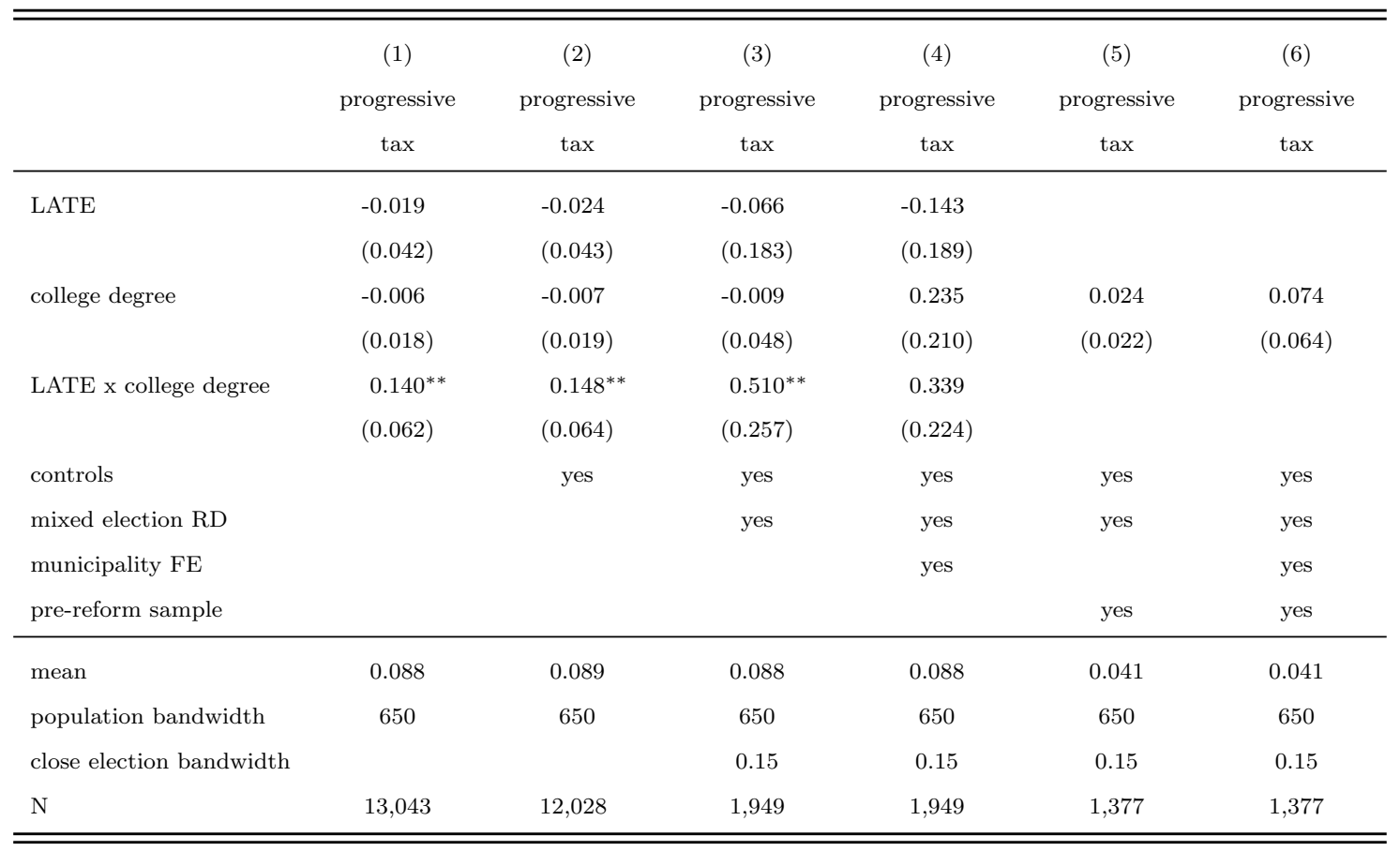

Notes: The reform is the introduction of the fiscal rule for municipalities above 1,000 inhabitants in 2013. The sample is restricted to observations for which we were able to match the main dataset with the election data. Columns (1), (2), (3) and (4) report estimates of the differencein-discontinuities model extended to estimate heterogeneous treatment effects. In rows with "mixed election RD" switched on, the model is augmented with the margin of victory and its interaction with all other terms, and the sample is further restricted to municipality-year observations, in which the incumbent mayor was elected in a race against a runner up with a different education level (college vs. non-college). Population bandwidths are selected following Grembi et al. (2016). Election bandwidths are selected using the using the STATA command rdrobust. Columns (5) and (6) report estimates of the college effect from regression discontinuity models where the running variable is the margin of victory, the treatment dummy is equal to one if the mayors holds a college degree, and the sample is restricted to years before the reform $\left(\beta_{2}\right)$ in equation 4. Details on all covariates are described in Section 4. In the bottom panel, the sample mean of the outcome variable, the used bandwidths and the number of observations are shown. Statistical significance denoted as: ${ }^{*} p<0.1,{ }^{* *} p<0.05,{ }^{* * *} p<0.01$ 
Table C.6: Differential effect of the reform by mayor's skill: mixed election RD

\begin{tabular}{|c|c|c|c|c|c|c|}
\hline & $\begin{array}{c}(1) \\
\text { exemption } \\
\text { level }\end{array}$ & $\begin{array}{c}(2) \\
\text { exemption } \\
\text { level }\end{array}$ & $\begin{array}{c}(3) \\
\text { exemption } \\
\text { level }\end{array}$ & $\begin{array}{c}(4) \\
\text { exemption } \\
\text { level }\end{array}$ & $\begin{array}{c}(5) \\
\text { exemption } \\
\text { level }\end{array}$ & $\begin{array}{c}(6) \\
\text { exemption } \\
\text { level }\end{array}$ \\
\hline LATE & $\begin{array}{c}-72 \\
(498)\end{array}$ & $\begin{array}{c}-87 \\
(502)\end{array}$ & $\begin{array}{l}-1550 \\
(2280)\end{array}$ & $\begin{array}{c}-932 \\
(2368)\end{array}$ & & \\
\hline college degree & $\begin{array}{l}-118 \\
(163)\end{array}$ & $\begin{array}{l}-116 \\
(177)\end{array}$ & $\begin{array}{l}-182 \\
(539)\end{array}$ & $\begin{array}{c}941 \\
(2092)\end{array}$ & $\begin{array}{c}116 \\
(209)\end{array}$ & $\begin{array}{c}386 \\
(526)\end{array}$ \\
\hline LATE $x$ college degree & $\begin{array}{r}1440^{*} \\
(735)\end{array}$ & $\begin{array}{r}1458^{*} \\
(754)\end{array}$ & $\begin{array}{l}5694^{*} \\
(3130)\end{array}$ & $\begin{array}{c}3007 \\
(2848)\end{array}$ & & \\
\hline $\begin{array}{l}\text { controls } \\
\text { mixed election } \mathrm{RD}\end{array}$ & & yes & $\begin{array}{l}\text { yes } \\
\text { yes }\end{array}$ & $\begin{array}{l}\text { yes } \\
\text { yes }\end{array}$ & $\begin{array}{l}\text { yes } \\
\text { yes }\end{array}$ & $\begin{array}{l}\text { yes } \\
\text { yes }\end{array}$ \\
\hline $\begin{array}{l}\text { municipality FE } \\
\text { pre-reform sample }\end{array}$ & & & & yes & yes & $\begin{array}{l}\text { yes } \\
\text { yes }\end{array}$ \\
\hline mean & 910.04 & 909.19 & 862.72 & 862.72 & 371.17 & 371.17 \\
\hline $\begin{array}{l}\text { population bandwidth } \\
\text { close election bandwidth }\end{array}$ & 635 & 635 & $\begin{array}{l}635 \\
0.16\end{array}$ & $\begin{array}{l}635 \\
0.16\end{array}$ & $\begin{array}{l}635 \\
0.16\end{array}$ & $\begin{array}{l}635 \\
0.16\end{array}$ \\
\hline $\mathrm{N}$ & 12,764 & 11,770 & 2,119 & 2,119 & 1,509 & 1,509 \\
\hline
\end{tabular}

Notes: The reform is the introduction of the fiscal rule for municipalities above 1,000 inhabitants in 2013. The sample is restricted to observations for which we were able to match the main dataset with the election data. Columns (1), (2), (3) and (4) report estimates of the differencein-discontinuities model extended to estimate heterogeneous treatment effects. In rows with "mixed election RD" switched on, the model is augmented with the margin of victory and its interaction with all other terms, and the sample is further restricted to municipality-year observations, in which the incumbent mayor was elected in a race against a runner up with a different education level (college vs. non-college). Population bandwidths are selected following Grembi et al. (2016). Election bandwidths are selected using the using the STATA command rdrobust. Columns (5) and (6) report estimates of the college effect from regression discontinuity models where the running variable is the margin of victory, the treatment dummy is equal to one if the mayors holds a college degree, and the sample is restricted to years before the reform $\left(\beta_{2}\right)$ in equation 4. Details on all covariates are described in Section 4. In the bottom panel, the sample mean of the outcome variable, the used bandwidths and the number of observations are shown. Statistical significance denoted as: ${ }^{*} p<0.1,{ }^{* *} p<0.05,{ }^{* * *} p<0.01$ 
Table C.7: Differential effect of the reform by mayor's skill: mixed election RD

\begin{tabular}{|c|c|c|c|c|c|c|}
\hline & $\begin{array}{l}\text { (1) } \\
\text { marginal rate } \\
\text { progression }\end{array}$ & $\begin{array}{l}\text { (2) } \\
\text { marginal rate } \\
\text { progression }\end{array}$ & $\begin{array}{l}\text { (3) } \\
\text { marginal rate } \\
\text { progression }\end{array}$ & $\begin{array}{c}\text { (4) } \\
\text { marginal rate } \\
\text { progression }\end{array}$ & $\begin{array}{l}\text { (5) } \\
\text { marginal rate } \\
\text { progression }\end{array}$ & $\begin{array}{c}\quad(6) \\
\text { marginal rate } \\
\text { progression }\end{array}$ \\
\hline LATE & $\begin{array}{l}-0.022 \\
(0.105)\end{array}$ & $\begin{array}{l}-0.034 \\
(0.105)\end{array}$ & $\begin{array}{l}-0.157 \\
(0.387)\end{array}$ & $\begin{array}{l}-0.317 \\
(0.392)\end{array}$ & & \\
\hline college degree & $\begin{array}{l}-0.045 \\
(0.029)\end{array}$ & $\begin{array}{l}-0.049 \\
(0.031)\end{array}$ & $\begin{array}{c}0.017 \\
(0.103)\end{array}$ & $\begin{array}{c}0.303 \\
(0.390)\end{array}$ & $\begin{array}{c}0.022 \\
(0.041)\end{array}$ & $\begin{array}{c}0.072 \\
(0.078)\end{array}$ \\
\hline LATE $x$ college degree & $\begin{array}{l}0.320^{* *} \\
(0.146)\end{array}$ & $\begin{array}{l}0.335^{* *} \\
(0.153)\end{array}$ & $\begin{array}{l}1.077^{* *} \\
(0.524)\end{array}$ & $\begin{array}{l}0.828^{*} \\
(0.478)\end{array}$ & & \\
\hline controls & & yes & yes & yes & yes & yes \\
\hline $\begin{array}{l}\text { mixed election } \mathrm{RD} \\
\text { municipality } \mathrm{FE}\end{array}$ & & & yes & $\begin{array}{l}\text { yes } \\
\text { yes }\end{array}$ & yes & $\begin{array}{l}\text { yes } \\
\text { yes }\end{array}$ \\
\hline pre-reform sample & & & & & yes & yes \\
\hline mean & 0.184 & 0.184 & 0.175 & 0.175 & 0.081 & 0.081 \\
\hline population bandwidth & 668 & 668 & 668 & 668 & 668 & 668 \\
\hline close election bandwidth & & & 0.18 & 0.18 & 0.18 & 0.18 \\
\hline $\mathrm{N}$ & 13,384 & 12,355 & 2,418 & 2,418 & 1,725 & 1,725 \\
\hline
\end{tabular}

Notes: The reform is the introduction of the fiscal rule for municipalities above 1,000 inhabitants in 2013. The sample is restricted to observations for which we were able to match the main dataset with the election data. Columns (1), (2), (3) and (4) report estimates of the differencein-discontinuities model extended to estimate heterogeneous treatment effects. In rows with "mixed election RD" switched on, the model is augmented with the margin of victory and its interaction with all other terms, and the sample is further restricted to municipality-year observations, in which the incumbent mayor was elected in a race against a runner up with a different education level (college vs. non-college). Population bandwidths are selected following Grembi et al. (2016). Election bandwidths are selected using the using the STATA command rdrobust. Columns (5) and (6) report estimates of the college effect from regression discontinuity models where the running variable is the margin of victory, the treatment dummy is equal to one if the mayors holds a college degree, and the sample is restricted to years before the reform $\left(\beta_{2}\right)$ in equation 4. Details on all covariates are described in Section 4. In the bottom panel, the sample mean of the outcome variable, the used bandwidths and the number of observations are shown. Statistical significance denoted as: ${ }^{*} p<0.1,{ }^{* *} p<0.05,{ }^{* * *} p<0.01$ 
Table C.8: Effects of the reform on mayors' reelection odds

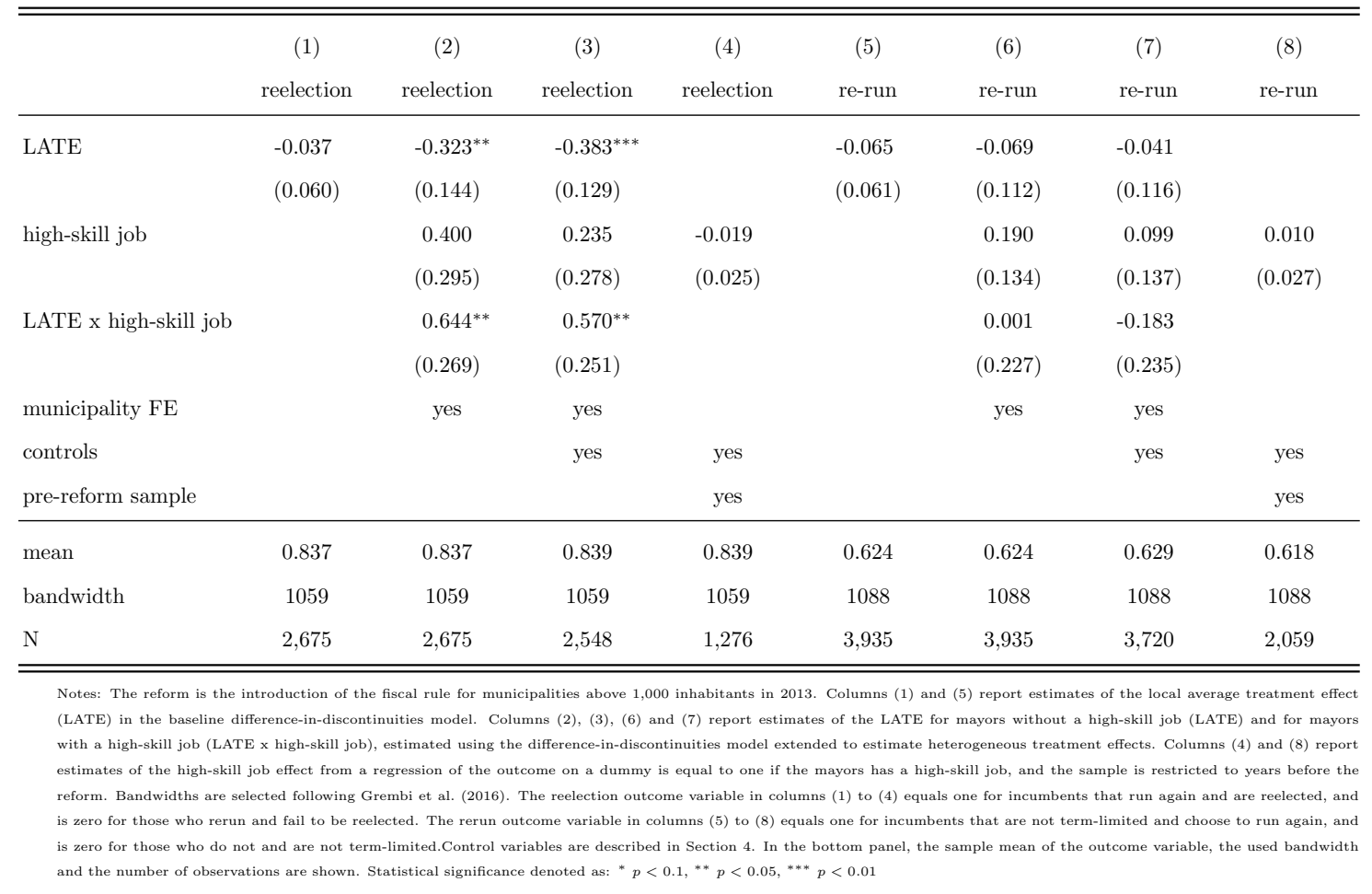

Table C.9: Effect of the reform on property tax rates

(3)

property tax on main dwellings property tax on other dwellings deduction amount

\begin{tabular}{lccc}
\hline LATE & 0.070 & 0.065 & 0.969 \\
& $(0.053)$ & $(0.074)$ & $(1.026)$ \\
\hline mean & 4.203 & 8.538 & 198.891 \\
bandwidth & 724 & 651 & 738 \\
$\mathrm{~N}$ & 7.949 & 7.227 & 8.097 \\
\hline \hline
\end{tabular}

Notes: The reform is the introduction of the fiscal rule for municipalities above 1,000 inhabitants in 2013. The top panel reports the local average treatment effect (LATE) of the difference-in-discontinuities model estimated with a separate local linear regression for each outcome variable (reported at the top of each column). The LATE corresponds to $\beta_{6}$ in equation 2. The bandwidth is selected following Grembi et al. (2016). Outcome variables are reported on top of each column. The sample includes the years 2012 to 2015. In the bottom panel, the sample mean of the outcome variable, the used bandwidth and the number of observations are shown. Statistical significance denoted as: ${ }^{*} p<0.1,{ }^{* *} p<0.05,{ }^{* * *} p<0.01$ 
Figure C.4: Effect of the reform on municipal expenditures by categories

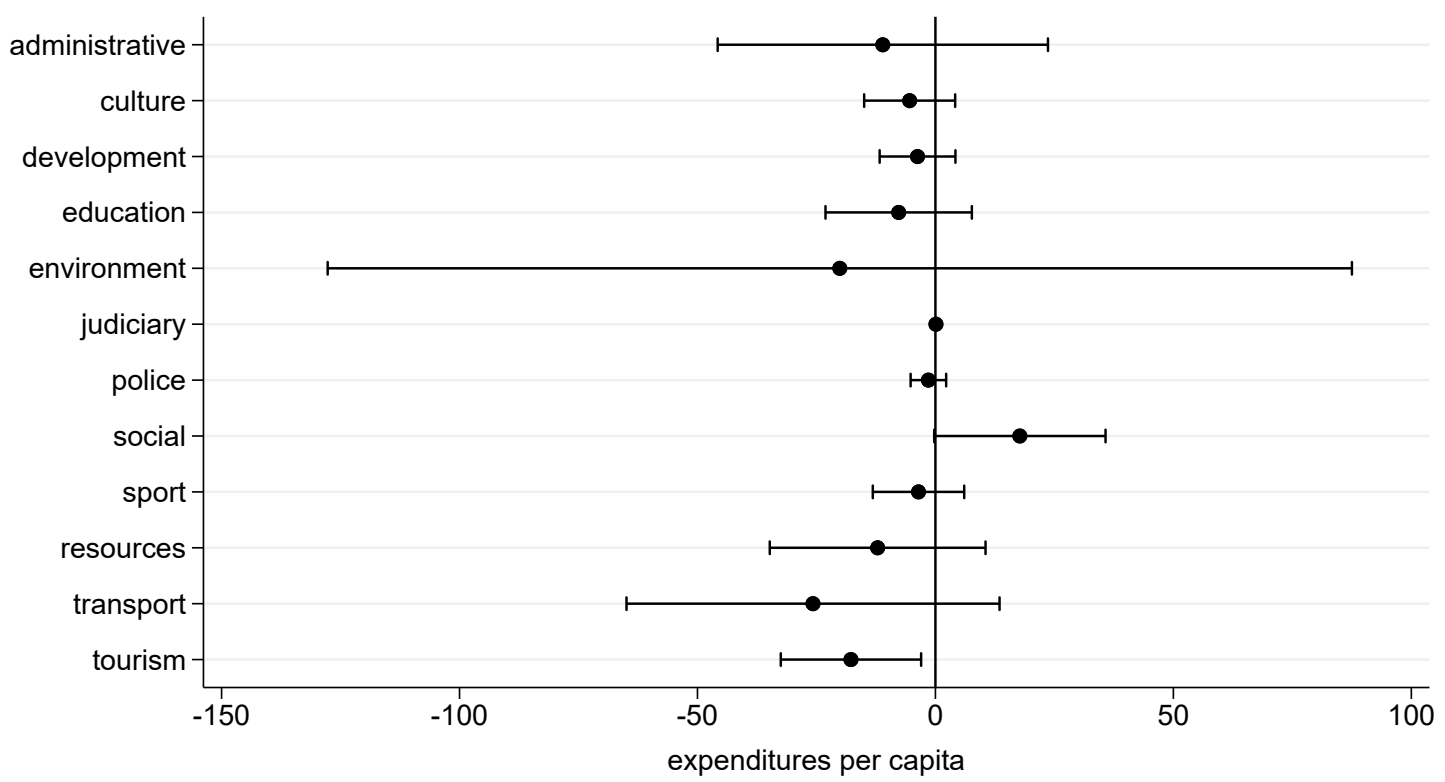

Notes: The reform is the introduction of the fiscal rule for municipalities above 1,000 inhabitants in 2013. The figure plots the LATE corresponding to $\beta_{6}$ in equation 2 and its $95 \%$ confidence bands. The bandwidth is selected following Grembi et al. (2016). Outcome variables are reported on top of each column. All variables are expressed in per capita terms and 2015 Euros and are winsorized.

Table C.10: Differential effect of the reform by mayor's skill

\begin{tabular}{|c|c|c|c|c|c|c|}
\hline & $\frac{(1)}{\text { exp: administrative }}$ & $\begin{array}{c}(2) \\
\text { exp: culture }\end{array}$ & $\begin{array}{c}(3) \\
\text { exp: development }\end{array}$ & exp: education & $\begin{array}{c}(5) \\
\text { exp: environment }\end{array}$ & $\begin{array}{c}(6) \\
\text { exp: judiciary }\end{array}$ \\
\hline \multirow[t]{2}{*}{ LATE } & -19.07 & 1.50 & -1.95 & -6.96 & -54.82 & -0.03 \\
\hline & $(17.02)$ & $(5.11)$ & $(3.30)$ & $(10.22)$ & $(60.10)$ & $(0.08)$ \\
\hline \multirow[t]{2}{*}{ LATE $x$ college degree } & 47.95 & -3.91 & -5.48 & -3.57 & 93.65 & 0.15 \\
\hline & $(34.15)$ & $(9.03)$ & $(6.96)$ & $(16.26)$ & $(105.79)$ & $(0.12)$ \\
\hline municipality FE & yes & yes & yes & yes & yes & yes \\
\hline controls & yes & yes & yes & yes & yes & yes \\
\hline mean & 418.10 & 21.28 & 11.73 & 104.06 & 379.13 & 0.19 \\
\hline bandwidth & 514 & 664 & 694 & 583 & 509 & 530 \\
\hline \multirow[t]{3}{*}{$\mathrm{N}$} & 13,397 & 16,918 & 17,618 & 15,036 & 13,306 & 13,738 \\
\hline & (7) & $(8)$ & (9) & $(10)$ & (11) & $(12)$ \\
\hline & exp: police & exp: social & exp: sport & exp: resources & exp: transport & exp: tourism \\
\hline \multirow[t]{2}{*}{ LATE } & 0.59 & 4.31 & -6.73 & -9.68 & -28.19 & $-12.81^{*}$ \\
\hline & $(1.77)$ & $(10.44)$ & $(5.41)$ & $(9.63)$ & $(20.84)$ & $(6.85)$ \\
\hline \multirow[t]{2}{*}{ LATE $x$ college degree } & 1.03 & 1.62 & 9.58 & $28.80^{*}$ & 44.90 & 4.98 \\
\hline & $(3.27)$ & $(16.52)$ & $(8.62)$ & $(16.12)$ & $(37.95)$ & $(12.92)$ \\
\hline municipality FE & yes & yes & yes & yes & yes & yes \\
\hline controls & yes & yes & yes & yes & yes & yes \\
\hline mean & 32.38 & 84.83 & 29.58 & 23.14 & 225.53 & 25.72 \\
\hline bandwidth & 640 & 549 & 777 & 564 & 591 & 688 \\
\hline $\mathrm{N}$ & 16,359 & 14,225 & 19,469 & 14,577 & 15,216 & 17,486 \\
\hline
\end{tabular}

Notes: The reform is the introduction of the fiscal rule for municipalities above 1,000 inhabitants in 2013. The table reports estimates of difference-in-discontinuities models extended to estimate heterogeneous treatment effects. The extended models include one or more binary covariates and their interactions with all the terms included in the baseline model. The row LATE reports the local average treatment effect in case the additional interaction variables are equal to zero $\left(\beta_{6}\right)$, while the interaction rows report the differential effects when the interaction variables are switched on $\left(\beta_{6}^{\text {int }}\right)$ in equation 3. Details on all covariates are described in Section 4. The estimation method is local linear regression. The bandwidth is selected following Grembi et al. (2016). In the bottom panel, the sample mean of the outcome variable, the used bandwidth and the number of observations are shown. Statistical significance denoted as: ${ }^{*} p<0.1,{ }^{* *} p<0.05,{ }^{* * *} p<0.01$ 


\section{Robustness Tests}

Figure D.1: Dynamic model: other outcomes

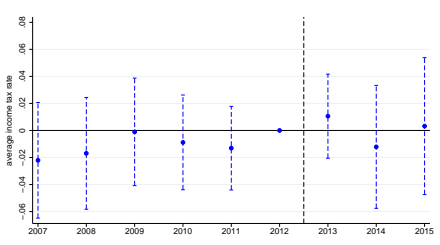

(a) 2nd decile

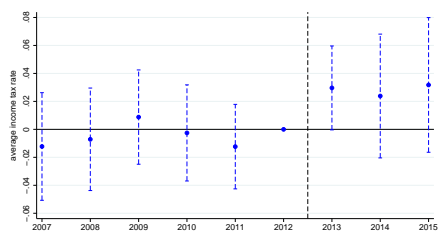

(d) 5 th decile

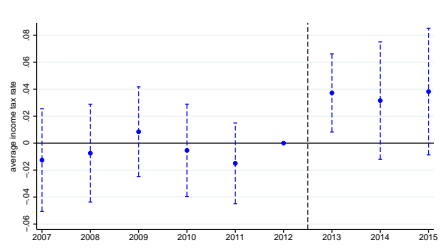

(g) 8th decile

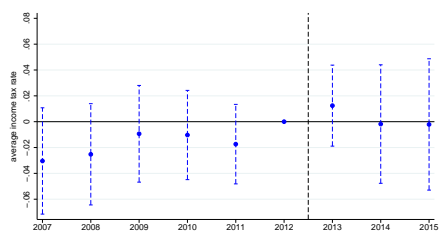

(b) 3rd decile

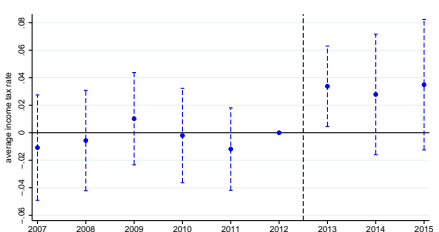

(e) 6th decile

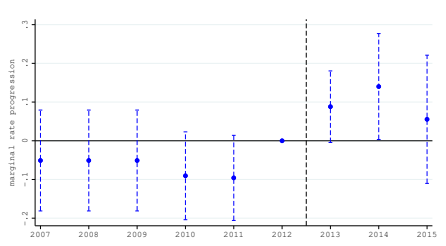

(h) marginal rate progression

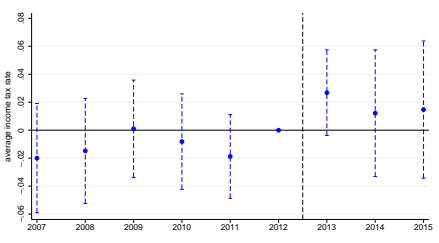

(c) 4th decile

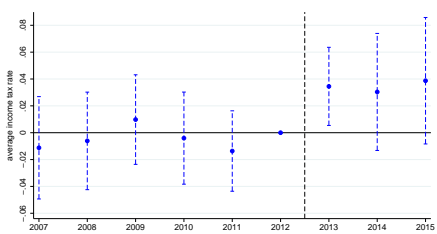

(f) 7 th decile

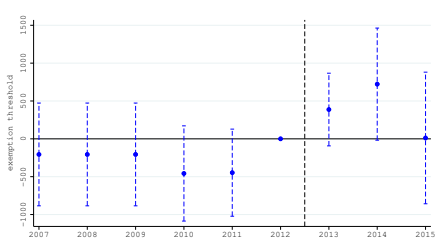

(i) exemption level

Notes: The reform is the introduction of the fiscal rule for municipalities above 1,000 inhabitants in 2013. Each panel plots estimates from the dynamic model on a different outcome variable, reported underneath each plot. The dynamic model is an extension of the baseline difference-in-discontinuities model that includes year dummies instead of the reform dummy. The bandwidth is selected following Grembi et al. (2016). Each dot is the estimate of the deviation of the outcome variable in the year reported on the horizontal axis relative to the pre-reform year 2012. Dotted bars are $95 \%$ confidence bands. 
Figure D.2: Income tax rates by municipal income deciles: placebo reforms

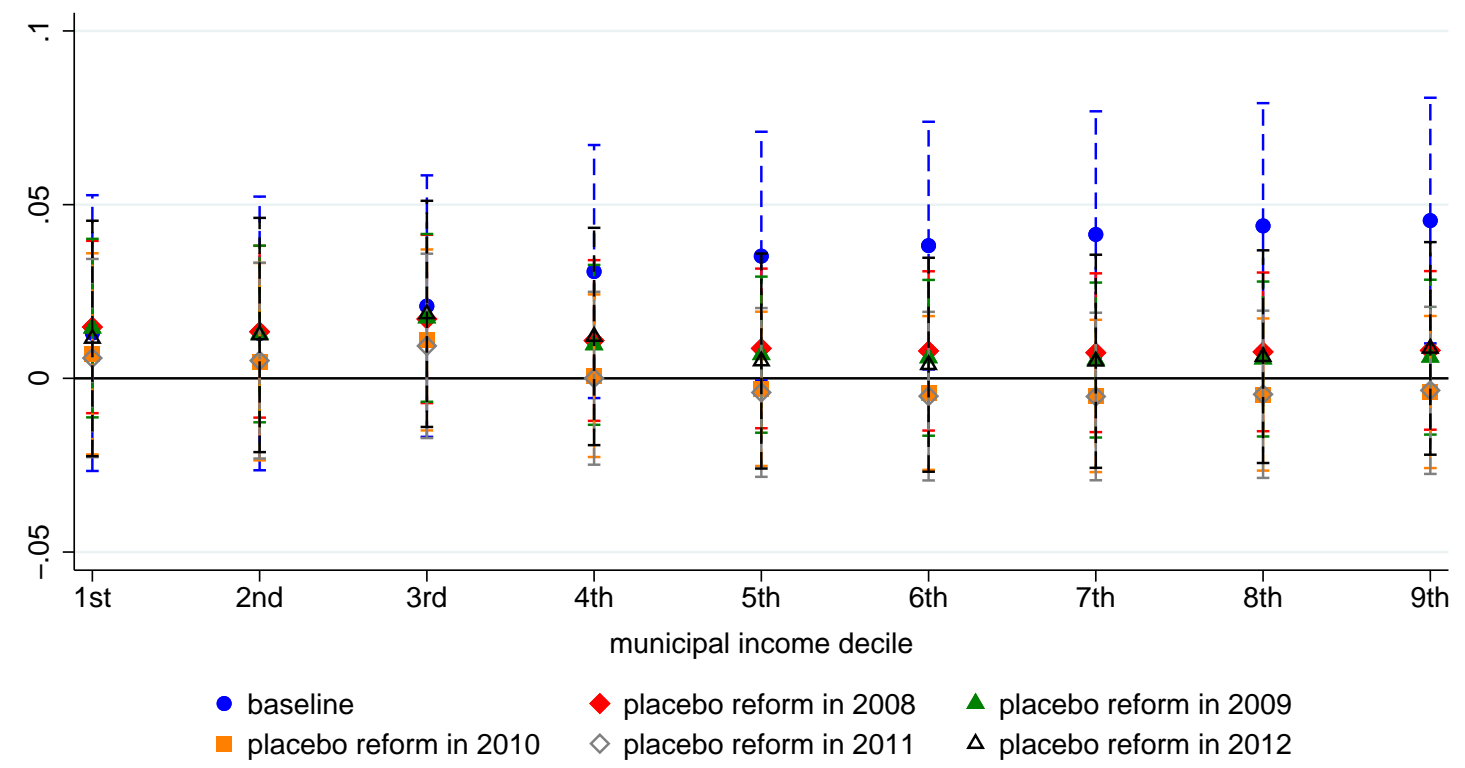

Notes: The blue line plots the local average treatment effect $\left(\beta_{6}\right)$ and its $95 \%$ confidence bands from Table 1 . All other lines plot placebo estimates. These are obtained by restricting the sample to pre-reform years, assigning the reform to a different year from 2008 to 2012 and finally re-estimating equation 2.

Table D.1: Continuity tests

\begin{tabular}{|c|c|c|c|c|c|c|c|c|}
\hline & $\begin{array}{c}\text { (1) } \\
\text { mayor: } \\
\text { female }\end{array}$ & $\begin{array}{c}(2) \\
\text { mayor: age }\end{array}$ & $\begin{array}{c}(3) \\
\text { mayor: } \\
\text { college } \\
\text { degree }\end{array}$ & $\begin{array}{c}(4) \\
\text { mayor: } \\
\text { high-skill } \\
\text { occupation }\end{array}$ & $\begin{array}{c}(5) \\
\text { mayor: } \\
\text { right-wing }\end{array}$ & $\begin{array}{c}(6) \\
\text { mayor: } \\
\text { left-wing }\end{array}$ & $\begin{array}{l}(7) \\
\text { mayor: } \\
\text { center }\end{array}$ & $\begin{array}{c}(8) \\
\text { mayor: term } \\
\text { limit }\end{array}$ \\
\hline LATE & $\begin{array}{l}-0.012 \\
(0.026)\end{array}$ & $\begin{array}{c}0.492 \\
(0.876)\end{array}$ & $\begin{array}{l}-0.007 \\
(0.037)\end{array}$ & $\begin{array}{l}-0.008 \\
(0.043)\end{array}$ & $\begin{array}{l}-0.003 \\
(0.011)\end{array}$ & $\begin{array}{c}0.001 \\
(0.028)\end{array}$ & $\begin{array}{c}0.000 \\
(0.007)\end{array}$ & $\begin{array}{l}-0.021 \\
(0.029)\end{array}$ \\
\hline mean & 0.118 & 52.029 & 0.361 & 0.312 & 0.023 & 0.108 & 0.011 & 0.287 \\
\hline bandwidth & 658 & 625 & 662 & 530 & 597 & 619 & 668 & 563 \\
\hline \multirow[t]{2}{*}{$\mathrm{N}$} & 17,404 & 16,565 & 17,238 & 13,946 & 15,917 & 16,464 & 17,670 & 15,046 \\
\hline & $\begin{array}{c}(9) \\
\text { share: age } \geq \\
60\end{array}$ & $\begin{array}{c}(10) \\
\text { share: female }\end{array}$ & $\begin{array}{c}(11) \\
\log \text { area }\end{array}$ & $\begin{array}{l}\text { (12) } \\
\text { coast dummy }\end{array}$ & $\begin{array}{l}\text { (13) } \\
\text { altitude (in } \\
\mathrm{m})\end{array}$ & $\begin{array}{c}(14) \\
\text { years to next } \\
\text { election }\end{array}$ & $\begin{array}{c}(15) \\
\text { top income } \\
\text { share }\end{array}$ & $\begin{array}{c}(16) \\
\log \text { taxable } \\
\text { income per } \\
\text { capita }\end{array}$ \\
\hline LATE & $\begin{array}{c}0.005 \\
(0.005)\end{array}$ & $\begin{array}{l}-0.002^{*} \\
(0.001)\end{array}$ & $\begin{array}{c}0.039 \\
(0.052)\end{array}$ & $\begin{array}{c}0.012^{*} \\
(0.007)\end{array}$ & $\begin{array}{l}-23.308 \\
(21.546)\end{array}$ & $\begin{array}{l}-0.066 \\
(0.077)\end{array}$ & $\begin{array}{c}0.006 \\
(0.005)\end{array}$ & $\begin{array}{c}0.020 \\
(0.014)\end{array}$ \\
\hline mean & 0.321 & 0.506 & 2.766 & 0.021 & 445.792 & 1.971 & 0.075 & 9.998 \\
\hline bandwidth & 586 & 621 & 587 & 581 & 526 & 511 & 614 & 658 \\
\hline $\mathrm{N}$ & 15,771 & 16,604 & 15,796 & 15,650 & 14,244 & 13,835 & 16,437 & 17,537 \\
\hline
\end{tabular}

Notes: The reform is the introduction of the fiscal rule for municipalities above 1,000 inhabitants in 2013. The top panel reports the local average treatment effect (LATE) of the difference-in-discontinuities model estimated with a separate local linear regression for each outcome variable (reported at the top of each column). The LATE corresponds to $\beta_{6}$ in equation 2 . The bandwidth is selected following Grembi et al. (2016). Outcome variables are reported on top of each column. In the bottom panel, the sample mean of the outcome variable, the used bandwidth and the number of observations are shown. Statistical significance denoted as: ${ }^{*} p<0.1,{ }^{* *} p<0.05,{ }^{* * *} p<0.01$ 
Figure D.4: Dynamic McCrary test

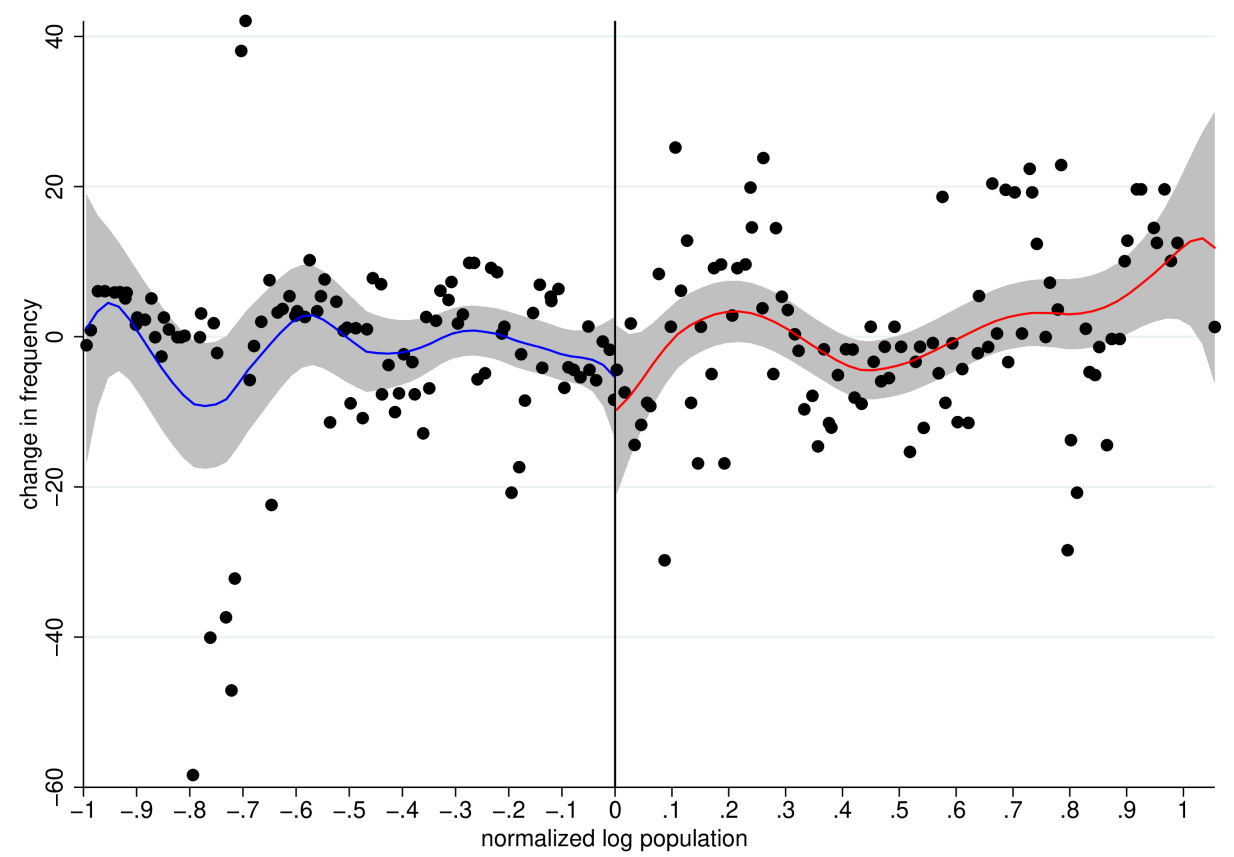

Notes: The figure presents the density plot for the difference-in-discontinuities design in the spirit of (McCrary, 2008). Each dot is the local average of the change in the total number of observations between the the pre- and post-reform periods within each bin of normalized $\log$ population. Each bin has width equal to 0.01 . The lines are fit of local polynomial using a quadratic degree and a triangular kernel. Grey bans are the corresponding $95 \%$ confidence bands.

Figure D.3: McCrary test before and after the reform

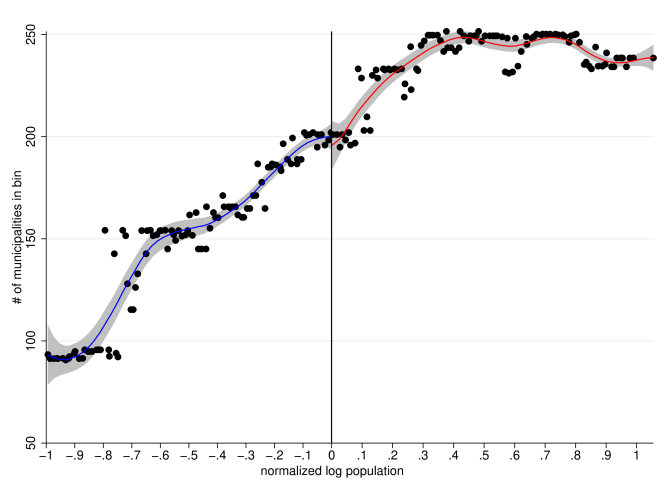

(a) pre-reform

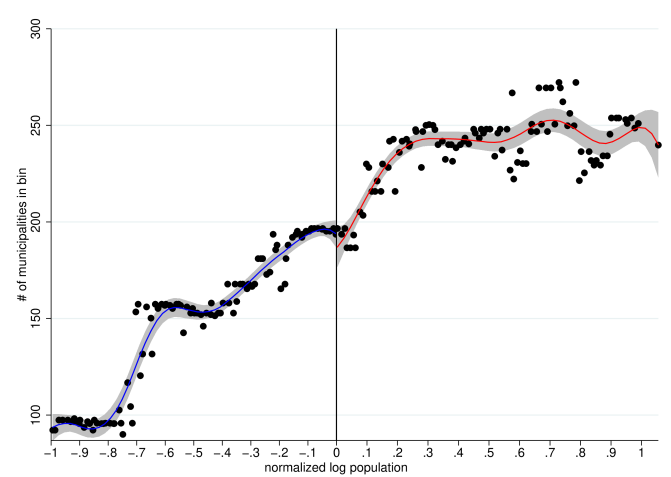

(b) post-reform

Notes: This figure presents McCrary density plots (McCrary, 2008). The left panel shows a pooled graph for all pre-reform years, while the right panel shows pool graph for all post-reform years. 
Figure D.5: Estimates by bandwidth

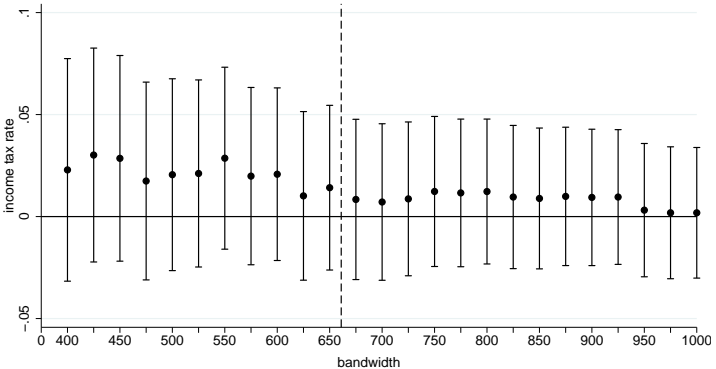

(a) Income tax rate at the first decile

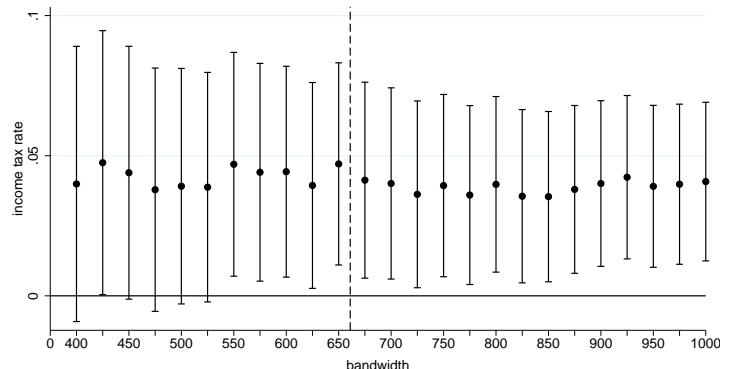

(b) Income tax rate at the 9 th decile

Notes: This figure plots the local average treatment effect $\left(\beta_{6}\right)$ and its $95 \%$ confidence bands reported in Table 1 for different bandwidths. The dashed vertical line refers to the optimal bandwidth.

Figure D.6: Income tax rates: global polynomial regressions

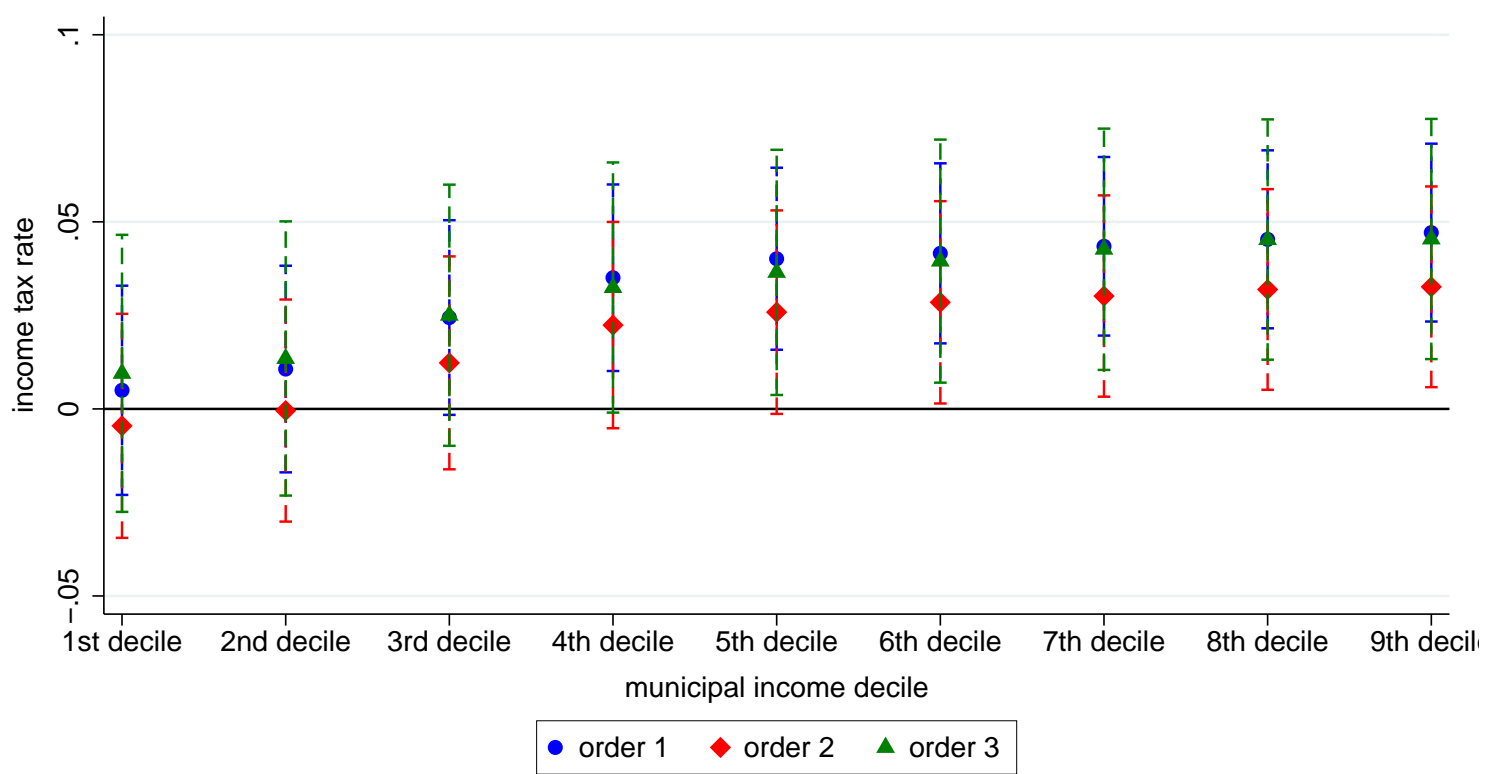

Notes: This figure plots the local average treatment effects reported in Table D.2 and their 95\% confidence bands 
Table D.2: Income tax rates: global polynomial regressions

\begin{tabular}{|c|c|c|c|c|c|c|c|c|c|}
\hline & (1) & (2) & (3) & (4) & (5) & (6) & (7) & (8) & (9) \\
\hline tax rate at & 1st decile & 2nd decile & 3rd decile & 4th decile & 5 th decile & 6 th decile & 7th decile & 8th decile & 9th decile \\
\hline \multicolumn{10}{|c|}{ polynomial of order 1} \\
\hline \multirow[t]{2}{*}{ LATE } & 0.005 & 0.011 & $0.024^{*}$ & $0.035^{* * *}$ & $0.040^{* * *}$ & $0.042^{* * *}$ & $0.043^{* * *}$ & $0.045^{* * *}$ & $0.047^{* * *}$ \\
\hline & $(0.014)$ & $(0.014)$ & $(0.013)$ & $(0.013)$ & $(0.012)$ & $(0.012)$ & $(0.012)$ & $(0.012)$ & $(0.012)$ \\
\hline mean & 0.329 & 0.332 & 0.346 & 0.358 & 0.364 & 0.367 & 0.368 & 0.369 & 0.371 \\
\hline $\mathrm{N}$ & 28,128 & 28,128 & 28,128 & 28,128 & 28,128 & 28,128 & 28,128 & 28,128 & 28,128 \\
\hline$>1$ st decile & - & 0.055 & 0.006 & 0.001 & 0.000 & 0.000 & 0.000 & 0.000 & 0.000 \\
\hline$>2$ nd decile & - & - & 0.024 & 0.002 & 0.001 & 0.001 & 0.000 & 0.000 & 0.000 \\
\hline$>$ 3rd decile & - & - & - & 0.029 & 0.012 & 0.010 & 0.006 & 0.004 & 0.003 \\
\hline$>4$ th decile & - & - & - & - & 0.125 & 0.097 & 0.056 & 0.036 & 0.026 \\
\hline$>5$ th decile & - & - & - & - & - & 0.252 & 0.100 & 0.056 & 0.040 \\
\hline$>6$ th decile & - & - & - & - & - & - & 0.066 & 0.042 & 0.030 \\
\hline$>7$ th decile & - & - & - & - & - & - & - & 0.102 & 0.051 \\
\hline$>8$ th decile & - & - & - & - & - & - & - & - & 0.075 \\
\hline \multicolumn{10}{|c|}{ polynomial of order 2} \\
\hline \multirow[t]{2}{*}{ LATE } & -0.005 & -0.000 & 0.012 & 0.022 & $0.026^{*}$ & $0.028^{* *}$ & $0.030^{* *}$ & $0.032^{* *}$ & $0.033^{* *}$ \\
\hline & $(0.015)$ & $(0.015)$ & $(0.015)$ & $(0.014)$ & $(0.014)$ & $(0.014)$ & $(0.014)$ & $(0.014)$ & $(0.014)$ \\
\hline mean & 0.329 & 0.332 & 0.346 & 0.358 & 0.364 & 0.367 & 0.368 & 0.369 & 0.371 \\
\hline $\mathrm{N}$ & 28,128 & 28,128 & 28,128 & 28,128 & 28,128 & 28,128 & 28,128 & 28,128 & 28,128 \\
\hline$>1$ st decile & - & 0.101 & 0.015 & 0.002 & 0.001 & 0.001 & 0.000 & 0.000 & 0.000 \\
\hline$>$ 2nd decile & - & - & 0.035 & 0.004 & 0.003 & 0.001 & 0.001 & 0.001 & 0.001 \\
\hline$>$ 3rd decile & - & - & - & 0.03 & 0.022 & 0.011 & 0.007 & 0.004 & 0.005 \\
\hline$>4$ th decile & - & - & - & - & 0.214 & 0.103 & 0.060 & 0.038 & 0.042 \\
\hline$>5$ th decile & - & - & - & - & - & 0.055 & 0.016 & 0.011 & 0.026 \\
\hline$>6$ th decile & - & - & - & - & - & - & 0.082 & 0.034 & 0.063 \\
\hline$>7$ th decile & - & - & - & - & - & - & - & 0.053 & 0.107 \\
\hline$>8$ th decile & - & - & - & - & - & - & - & - & 0.285 \\
\hline \multicolumn{10}{|c|}{ polynomial of order 3} \\
\hline \multirow[t]{2}{*}{ LATE } & 0.010 & 0.013 & 0.025 & $0.032^{*}$ & $0.036^{* *}$ & $0.039^{* *}$ & $0.043^{* * *}$ & $0.045^{* * *}$ & $0.045^{* * *}$ \\
\hline & $(0.019)$ & $(0.019)$ & $(0.018)$ & $(0.017)$ & $(0.017)$ & $(0.017)$ & $(0.016)$ & $(0.016)$ & $(0.016)$ \\
\hline mean & 0.329 & 0.332 & 0.346 & 0.358 & 0.364 & 0.367 & 0.368 & 0.369 & 0.371 \\
\hline $\mathrm{N}$ & 28,128 & 28,128 & 28,128 & 28,128 & 28,128 & 28,128 & 28,128 & 28,128 & 28,128 \\
\hline$>1$ st decile & - & 0.161 & 0.055 & 0.023 & 0.014 & 0.009 & 0.005 & 0.003 & 0.004 \\
\hline$>$ 2nd decile & - & - & 0.095 & 0.040 & 0.024 & 0.015 & 0.008 & 0.005 & 0.006 \\
\hline$>$ 3rd decile & - & - & - & 0.139 & 0.082 & 0.050 & 0.025 & 0.016 & 0.021 \\
\hline$>4$ th decile & - & - & - & - & 0.215 & 0.120 & 0.053 & 0.030 & 0.042 \\
\hline$>5$ th decile & - & - & - & - & - & 0.140 & 0.030 & 0.014 & 0.036 \\
\hline$>6$ th decile & - & - & - & - & - & - & 0.024 & 0.011 & 0.050 \\
\hline$>7$ th decile & - & - & - & - & - & - & - & 0.039 & 0.147 \\
\hline$>8$ th decile & - & - & - & - & - & - & - & - & 0.462 \\
\hline
\end{tabular}

Notes: The reform is the introduction of the fiscal rule for municipalities above 1,000 inhabitants in 2013. The top panel reports the local average treatment effect (LATE) of the difference-in-discontinuities model estimated with a separate global regression for each outcome variable (reported at the top of each column) on the sample of all municipalities below 2,500 inhabitants with different polynomial orders $n$. The deciles refer to the income distribution in each municipality. The middle panel displays p-values for pairwise one-sided tests (estimated by seemingly unrelated regression) whether the effect is higher than the effect on the tax rate at the first to eighth municipal income decile, respectively. In the bottom panel, the sample mean of the outcome variable, the used bandwidth and the number of observations are shown. Statistical significance denoted as: ${ }^{*} p<0.1{ }^{* *} p<0.05$, *** $p<0.01$ 
Figure D.7: Placebo thresholds

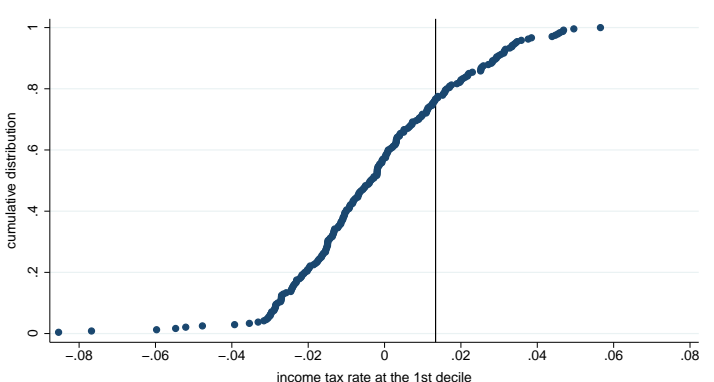

(a) tax rate at the 1 st decile

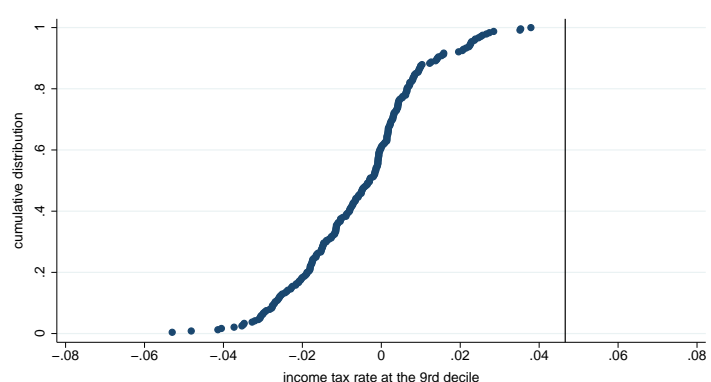

(b) tax rate at the 9 th decile

Notes: This figure plots the cumulative distribution of placebo estimates for the income tax rate at the first (panel a) and nineth decile (panel b). The placebo estimates are obtained by estimating equation 2 at false thresholds between 400 and 900 as well as 1,100 and 1,600 . The effect at the true threshold is indicated by the vertical line.

Table D.3: Mixed election disconuinity: covariate balancing

\begin{tabular}{|c|c|c|c|c|c|c|c|c|}
\hline & $\begin{array}{c}\text { (1) } \\
\text { mayor: } \\
\text { female }\end{array}$ & $\begin{array}{c}(2) \\
\text { mayor: age }\end{array}$ & $\begin{array}{c}\text { (3) } \\
\text { mayor: } \\
\text { political }\end{array}$ & $\begin{array}{c}\text { (4) } \\
\text { mayor: term } \\
\text { limit }\end{array}$ & $\begin{array}{l}(5) \\
\text { runner-up: } \\
\text { female }\end{array}$ & $\begin{array}{l}(6) \\
\text { runner-up: } \\
\text { age }\end{array}$ & $\begin{array}{l}(7) \\
\text { runner-up: } \\
\text { political }\end{array}$ & $\begin{array}{l}\text { (8) } \\
\text { years to } \\
\text { election }\end{array}$ \\
\hline RD estimate & $\begin{array}{l}0.187^{* * *} \\
(0.066)\end{array}$ & $\begin{array}{l}-2.602 \\
(1.872)\end{array}$ & $\begin{array}{l}-0.001 \\
(0.058)\end{array}$ & $\begin{array}{l}-0.071 \\
(0.060)\end{array}$ & $\begin{array}{l}-0.024 \\
(0.075)\end{array}$ & $\begin{array}{c}3.120 \\
(2.669)\end{array}$ & $\begin{array}{c}0.036 \\
(0.070)\end{array}$ & $\begin{array}{c}0.020 \\
(0.053)\end{array}$ \\
\hline mean & 0.131 & 51.227 & 0.130 & 0.155 & 0.128 & 52.016 & 0.182 & 1.977 \\
\hline bandwidth & 0.15 & 0.13 & 0.14 & 0.13 & 0.10 & 0.11 & 0.15 & 0.15 \\
\hline \multirow[t]{2}{*}{$\mathrm{N}$} & 2,223 & 2,001 & 2,010 & 2,001 & 1,668 & 1,740 & 2,063 & 2,229 \\
\hline & $\begin{array}{c}(9) \\
\text { share: college }\end{array}$ & $\begin{array}{c}(10) \\
\text { share: female }\end{array}$ & $\begin{array}{c}(11) \\
\text { share: age } \geq \\
60\end{array}$ & $\begin{array}{c}(12) \\
\log \text { area }\end{array}$ & $\begin{array}{c}(13) \\
\text { coast dummy }\end{array}$ & $\begin{array}{l}(14) \\
\text { altitude (in } \\
\mathrm{m})\end{array}$ & $\begin{array}{c}(15) \\
\text { top income } \\
\text { share }\end{array}$ & $\begin{array}{c}(16) \\
\log \text { taxable } \\
\text { income per } \\
\text { capita }\end{array}$ \\
\hline RD estimate & $\begin{array}{c}0.003 \\
(0.004)\end{array}$ & $\begin{array}{l}-0.002 \\
(0.003)\end{array}$ & $\begin{array}{l}-0.007 \\
(0.013)\end{array}$ & $\begin{array}{c}0.043 \\
(0.158)\end{array}$ & $\begin{array}{c}0.011 \\
(0.037)\end{array}$ & $\begin{array}{l}-15.828 \\
(49.379)\end{array}$ & $\begin{array}{c}0.013 \\
(0.014)\end{array}$ & $\begin{array}{l}-0.008 \\
(0.047)\end{array}$ \\
\hline mean & 0.069 & 0.507 & 0.321 & 2.886 & 0.018 & 478.622 & 0.069 & 9.306 \\
\hline bandwidth & 0.12 & 0.11 & 0.13 & 0.12 & 0.12 & 0.16 & 0.14 & 0.14 \\
\hline $\mathrm{N}$ & 1,892 & 1,750 & 2,001 & 1,834 & 1,852 & 2,375 & 2,027 & 2,108 \\
\hline
\end{tabular}

Notes: ${ }^{*} p<0.1,{ }^{* *} p<0.05,{ }^{* * *} p<0.01$; This table displays regression discontinuity estimates using the STATA command rdrobust in a mixed election regression discontinuity design for the whole sample period (Calonico et al., 2017). 
Figure D.8: McCrary test for mixed elections between college- and non-collegeeducated candidates

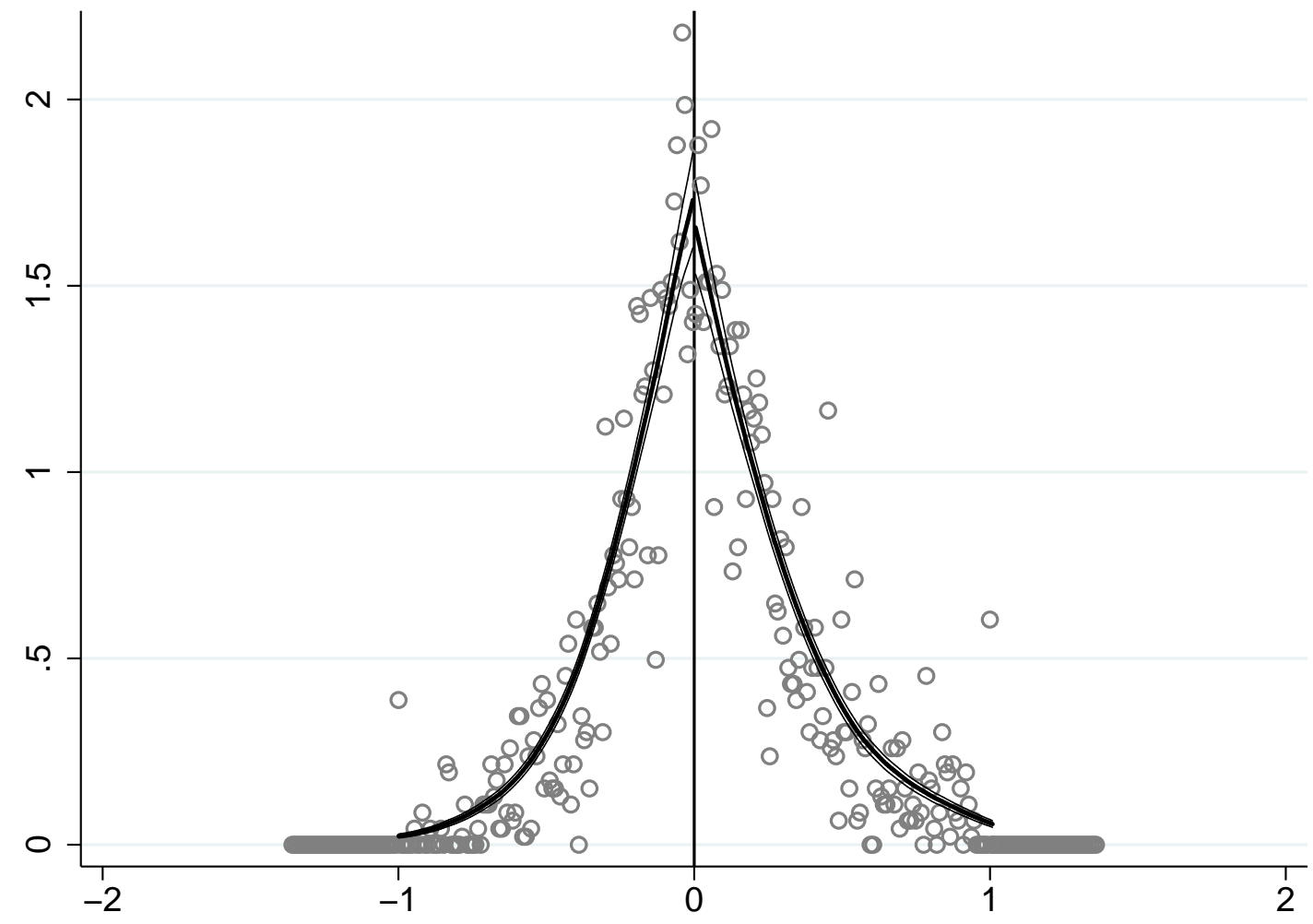

Notes: This figure presents the McCrary density plot for close elections between college- and non-college-educated candidates. 
Figure D.9: Close election RD: estimates by bandwidth

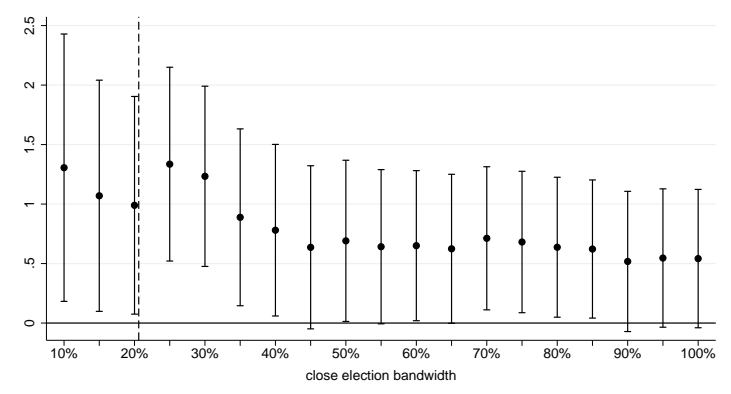

(a) average rate progression

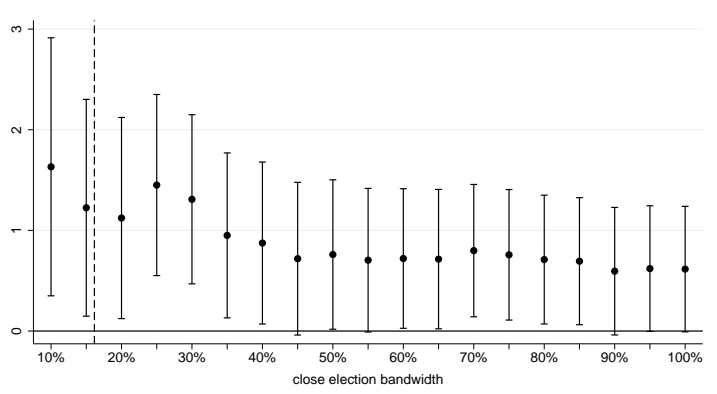

(c) marginal rate progression

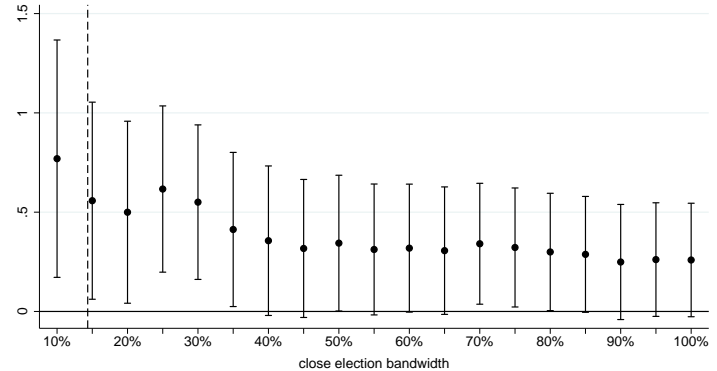

(b) progressive tax system

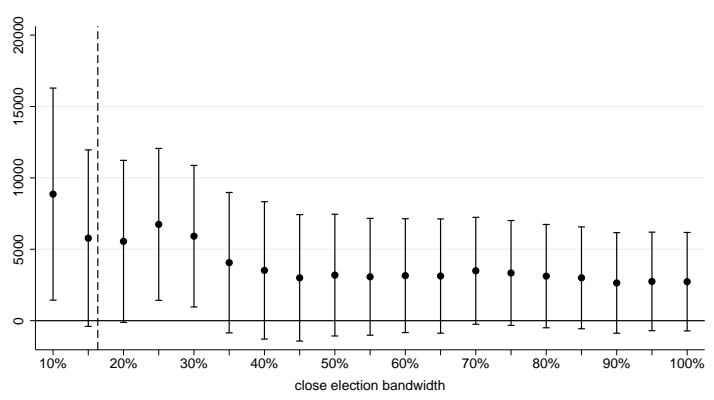

(d) exemption level

Notes: This figure plots the local average treatment interaction effect for the mayor having a college degree (LATE x college degree) and its 95\% confidence bands reported in Tables 5 (Panel a), C.5 (Panel b), C.7 (Panel c) and C.6 (Panel d) for different bandwidths. The dashed vertical line refers to the optimal bandwidth.

Figure D.10: Estimates by bandwidth: political outcomes

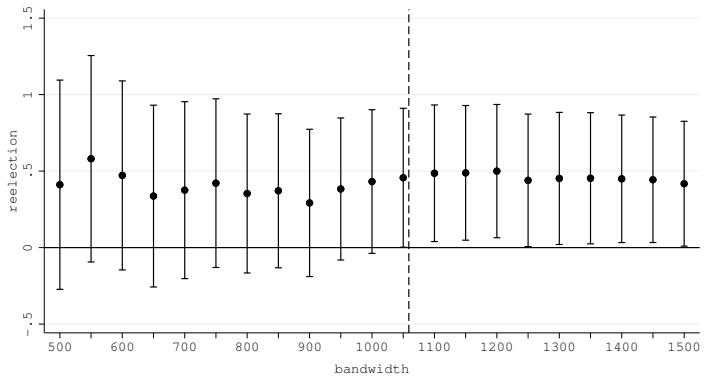

(a) reelection

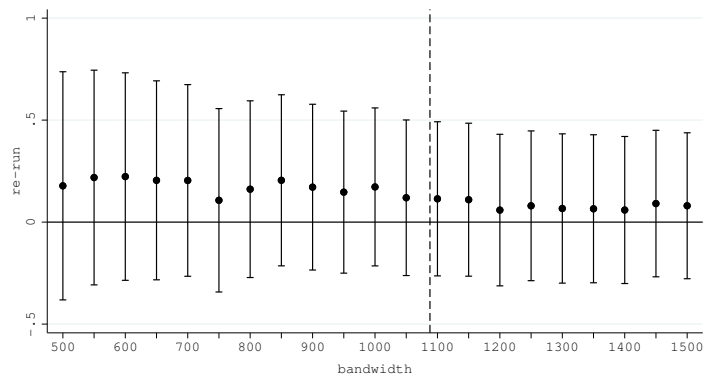

(b) re-run

Notes: This figure plots the local average treatment interaction effect for the mayor having a college degree (LATE $\mathrm{x}$ college degree) and its $95 \%$ confidence bands reported in Table 6 for different bandwidths. The dashed vertical line refers to the optimal bandwidth. 
Table D.4: Municipal budget accounts: placebo regressions

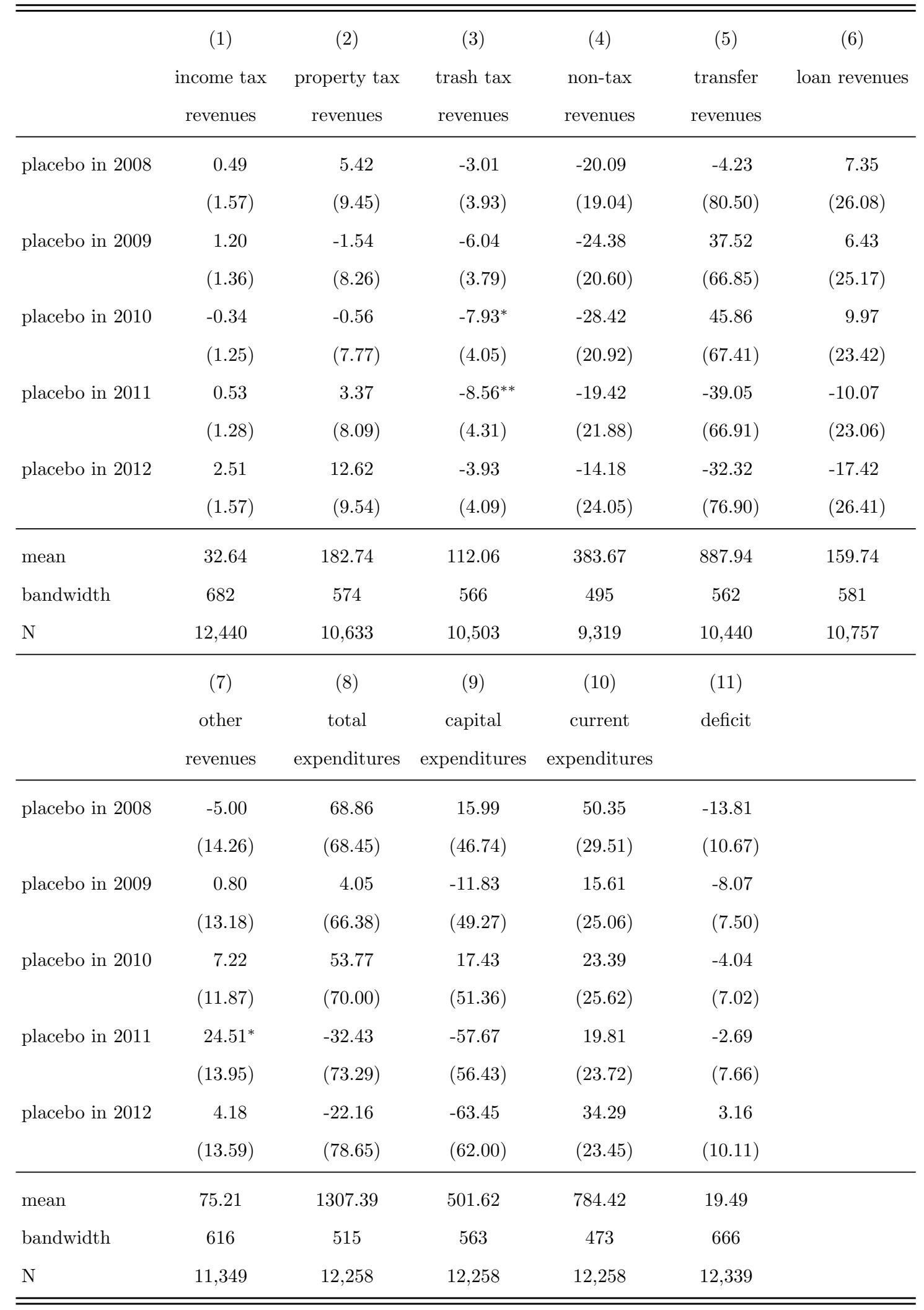

Notes: ${ }^{*} p<0.1,{ }^{* *} p<0.05,{ }^{* * *} p<0.01$; This table displays placebo effects using equation 2 . These are obtained by restricting the sample to pre-reform years, assigning the reform to a different year and finally re-estimating equation 2 . In the bottom panel, the sample mean of the outcome variable, the used bandwidth and the number of observations are shown. All revenue, expenditure, and deficit variables are expressed in per capita terms and 2015 Euros. 
Download ZEW Discussion Papers from our ftp server:

http://ftp.zew.de/pub/zew-docs/dp/

or see:

https://www.ssrn.com/link/ZEW-Ctr-Euro-Econ-Research.html

https://ideas.repec.org/s/zbw/zewdip.html

$$
\text { // }
$$

IMPRINT

ZEW - Leibniz-Zentrum für Europäische Wirtschaftsforschung GmbH Mannheim

ZEW - Leibniz Centre for European

Economic Research

L 7,1 68161 Mannheim · Germany

Phone +49621 1235-01

info@zew.de·zew.de

Discussion Papers are intended to make results of ZEW research promptly available to other economists in order to encourage discussion and suggestions for revisions. The authors are solely responsible for the contents which do not necessarily represent the opinion of the ZEW. 